\title{
Some Doubts About "Democratizing" Criminal Justice
}

\author{
John Rappaport†
}

The American criminal justice system's ills are by now so familiar as scarcely to bear repeating: unprecedented levels of incarceration, doled out disproportionately across racial groups, and police that seem to antagonize and hurt the nowdistrustful communities they are tasked to serve and protect. Systemic social ailments like these seldom permit straightforward diagnoses, let alone simple cures. In this case, however, a large, diverse, and influential group of experts-the legal academy's "democratizers"-all identify the same disease: the retreat of local democratic control in favor of a bureaucratic "machinery" disconnected from public values and the people themselves. Neighborhood juries, for example, internalize the costs of punishing their own; neighborhood police, "of" and answerable to the community, think twice before drawing their weapons or stopping a local boy on a hunch. The experts and detached professionals who populate our dominant bureaucratic institutions, in contrast, are motivated by different, less salubrious, incentives. Across the gamut of criminal justice decision-making, the democratizers maintain, the influence of the local laity is a moderating, equalizing, and ultimately legitimating one. A generous dose of participatory democracy won't solve all our problems, but it's our best shot to get the criminal justice system back on its feet.

This Article's warning is plain: don't take the medicine. "Democratization" wields undeniable rhetorical appeal but will not really fix what ails us-and may just make it worse. The democratization movement, this Article argues, rests on conceptually problematic and empirically dubious premises about the makeup, preferences, and independence of local "communities." It relies on the proudly counterintuitive claim that laypeople are largely lenient and egalitarian, contrary to a wealth of social scientific evidence. And ultimately, democratization's dual commitments are on a collision course. The democratizers simultaneously devote themselves to particular ends—amelioration of the biased and outsized carceral state — and to particular means-participatory democracy. What happens if, as this Article predicts,

$\dagger$ Assistant Professor of Law and Ludwig and Hilde Research Scholar, University of Chicago Law School. I am indebted to Monica Bell, Merav Bennett, Stephanos Bibas, Andrew Crespo, Justin Driver, Roger Fairfax, Trevor Gardner, Bernard Harcourt, Emma Kaufman, Brian Leiter, Richard McAdams, Tracey Meares, Martha Nussbaum, Dan Richman, Jocelyn Simonson, Roseanna Sommers, and Fred Smith for terrific comments on drafts. Thanks as well to Will Baude, Genevieve Lakier, Lauren Ouziel, and participants at the Criminal Justice Roundtable, the Junior Criminal Justice Roundtable, the University of Chicago Works-in-Progress Workshop, and the University of Virginia Faculty Workshop for generative conversations. For research assistance, thanks to Merav Bennett, Dylan Demello, Morgan Gehrls, Alli Hugi, Kevin Kennedy, and especially Alex Song. The Darelyn A. and Richard C. Reed Memorial Fund furnished financial support. 
the means do not produce the ends? Which commitment prevails? Worse yet, venerating lay opinion distracts from alternative visions of "democratic" criminal justice that more credibly tackle the critical question of how best to blend public accountability with evidence and expertise.

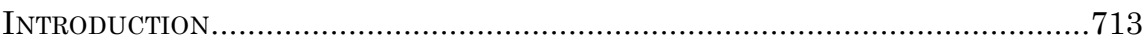

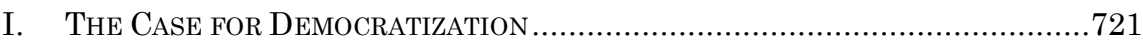

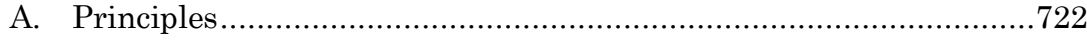

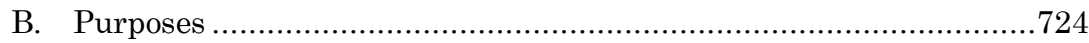

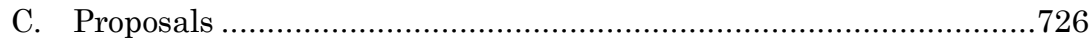

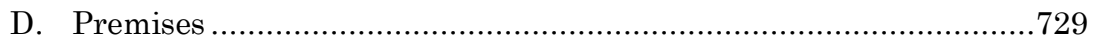

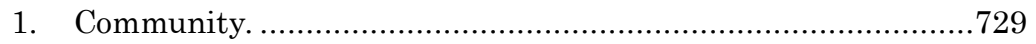

2. Lay leniency............................................................... 732

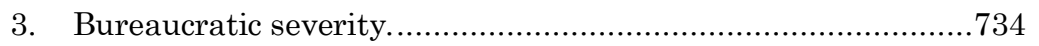

4. Equality.................................................................... 736

5. Compliance. .................................................................. 737

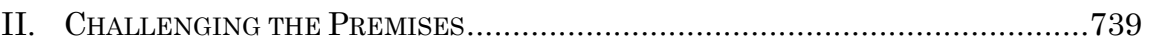

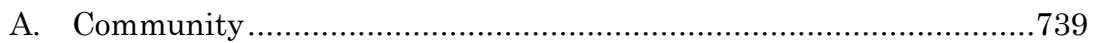

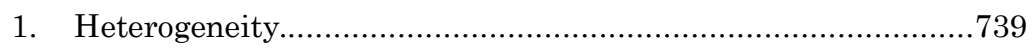

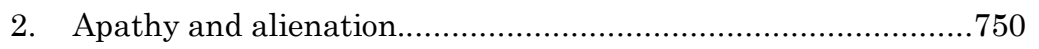

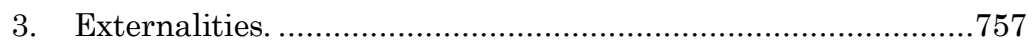

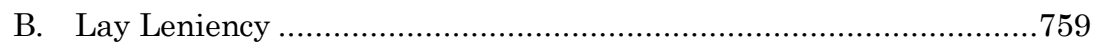

1. Wholesale leniency..................................................... 759

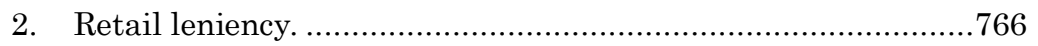

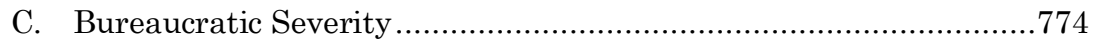

1. The comparative case................................................. 775

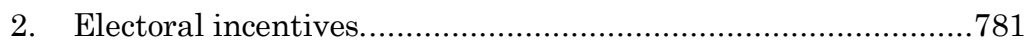

3. Repeat play.................................................................. 783

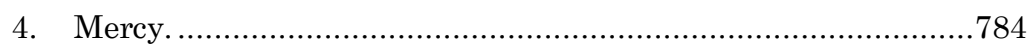

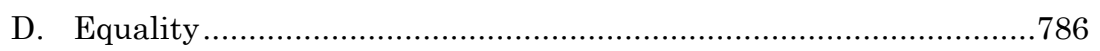

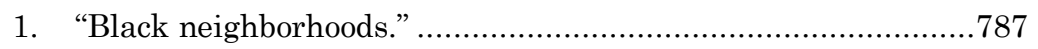

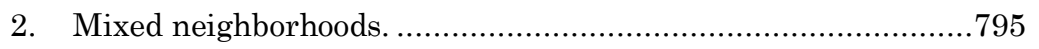

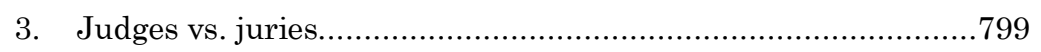

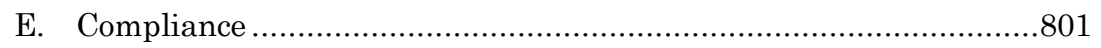

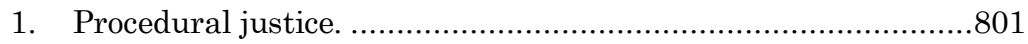

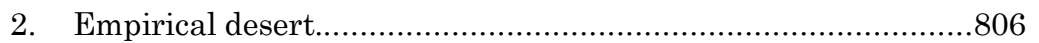

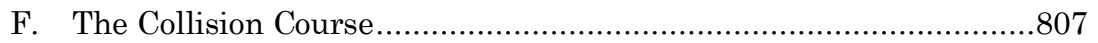

III. Conclusion: Alternative Visions of “Democratic” Criminal Justice 809 


\section{INTRODUCTION}

For the uninitiated, a brief rehearsal of the facts of the matter: The United States presently incarcerates over two million individuals, with another four million under other forms of correctional supervision. ${ }^{1}$ The nation's imprisonment rate is the highest in the world, ${ }^{2}$ while its crime rates are about average. ${ }^{3}$ One-third of American inmates are black. ${ }^{4}$ One in three black males in the United States will be incarcerated before he dies. ${ }^{5}$ Figures like these are far out of line with national population demographics and do not simply reflect differential rates of offending across racial groups. ${ }^{6}$ These "twin problems"- "overall severity" and "disparate treatment of African-Americans"7-plague American policing as well. American law enforcement officers killed over 1,100 individuals in 2017, more than 300 of them black. ${ }^{8}$ From 2004 to 2012 in New York City alone, police conducted 4.4 million pedestrian stops, targeting black individuals more than half the time. ${ }^{9}$

1 Danielle Kaeble and Mary Cowhig, Correctional Populations in the United States, 2016 *2 (US Department of Justice, Apr 2018), archived at https://perma.cc/GT2Z-LJKA.

2 Roy Walmsley, World Prison Population List *2 (Institute for Criminal Policy Research 12th ed 2018), archived at https://perma.cc/Q4XU-3DZW.

3 See Sara Sun Beale, What's Law Got to Do with It? The Political, Social, Psychological and Other Non-Legal Factors Influencing the Development of (Federal) Criminal Law, 1 Buff Crim L Rev 23, 37-38 (1997). The US homicide rate, for example, is below the world average. See Global Study on Homicide 2019*11, 27 (UN Office on Drugs and Crime, Apr 2019), archived at https://perma.cc/BR3S-F5JQ.

4 See E. Ann Carson, Prisoners in 2016*5 tbl 3 (US Department of Justice, Jan 2018), archived at https://perma.cc/3DYA-DQYR.

5 Thomas P. Bonczar, Prevalence of Imprisonment in the US Population, 1974-2001 *1 (US Department of Justice, Aug 2003), archived at https://perma.cc/3X7D-TSAG. The one-in-three statistic has been criticized as stale, though a conservative updated estimate still puts it at one in four. See Glenn Kessler, The Stale Statistic That One in Three Black Males 'Born Today' Will End Up in Jail (Wash Post, June 16, 2015), online at https://www.washingtonpost.com/news/fact-checker/wp/2015/06/16/the-stale-statistic -that-one-in-three-black-males-has-a-chance-of-ending-up-in-jail/ (visited Feb 19, 2020) (Perma archive unavailable).

6 See Nazgol Ghandnoosh, Race and Punishment: Racial Perceptions of Crime and Support for Punitive Policies *20-22 (The Sentencing Project, Sept 2014), archived at https://perma.cc/UB68-WHCB.

7 John Paul Stevens, Book Review, Our 'Broken System' of Criminal Justice (NY Rev Books, Nov 10, 2011), archived at https://perma.cc/WD92-XLYX.

8 See 2017 Police Violence Report (Mapping Police Violence), archived at https://perma.cc/38L8-3RQ3.

9 Floyd $v$ City of New York, 959 F Supp 2d 540, 558-59 (SDNY 2013). 
Unsurprisingly, public attitudes toward, and trust in, law enforcement diverge sharply along racial lines. ${ }^{10}$ Talk of a crisis of legitimacy in American policing is commonplace. ${ }^{11}$

Given broad academic consensus on these points, the pressing questions are how we got here and, especially, how we can get out. Theories proliferate. Notably, though, a diverse and accomplished group of scholars, following different intellectual paths, have recently converged upon the same basic conclusion. The retreat of local democratic control over criminal justice, these writers argue, precipitated the system's collapse; to reverse course, reformers must curb the influence of bureaucrats and redirect power to local communities to stimulate "bottom-up populism." 12 Aspects of this account have a decidedly counterintuitive cast: they require us to accept that politically liberal reforms to professionalize police and prosecutors, protect minority rights, and ensure equality of punishment across defendants had unintended and ultimately perverse effects. Yet however counterintuitive the theory may have been at its inception, the notion that we ought to "trad[e] a good deal of expertise for a little democracy," wrote Professor David Sklansky in 2008, "probably reflects the general view among scholars today." 13

The thesis is perhaps most strongly associated with the late Professor Bill Stuntz, the preeminent criminal procedure scholar of his generation. "14 "For much of American history," Stuntz

10 Only 30 percent of African Americans report a high degree of trust in the police as compared to 45 percent of Hispanics and 61 percent of whites. Jim Norman, Confidence in Police Back at Historical Average (Gallup, July 10, 2017), archived at https://perma.cc/LV2B-QYGJ.

11 See, for example, President's Task Force on 21st Century Policing, Final Report of the President's Task Force on 21st Century Policing *9-11 (US Department of Justice Office of Community Oriented Policing Services, May 2015), archived at https://perma.cc/9LN5-28UA; Monica C. Bell, Police Reform and the Dismantling of Legal Estrangement, 126 Yale L J 2054, 2058-59 (2017) (explaining that "[m]any scholars and policymakers have settled on a 'legitimacy deficit' as the core diagnosis of the frayed relationship between police forces and the communities they serve").

12 Stephanos Bibas, The Machinery of Criminal Justice xxvi (Oxford 2012).

13 David Alan Sklansky, Democracy and the Police 230 n 81 (Stanford 2008) (quotation marks omitted), quoting William J. Stuntz, The Pathological Politics of Criminal Law, 100 Mich L Rev 505, 586 (2001).

14 See Joshua Kleinfeld, Manifesto of Democratic Criminal Justice, $111 \mathrm{Nw}$ U L Rev 1367, 1403 (2017) (referring to Stuntz as "a founding father of the democratization point of view" who "would have been among us [democratizers] had he lived"). Reading Stuntz's work as a whole, the actual extent of its overlap with the democratization agenda is unclear. Stuntz, "hardly an unqualified foe of judicial activism," was "deeply committed to the project of rationalist reform" and rejected a criminal law designed to express or reflect moral values rather than, fundamentally, to govern. See David Alan Sklansky, Stealing 
writes, "outside the South[,] criminal justice institutions punished sparingly, mostly avoided the worst forms of discrimination, controlled crime effectively, and, for the most part, treated those whom the system targets fairly." 15 Then, around the end of the Gilded Age, coincident with the Great Migration of African Americans to Northern cities, crime began to concentrate in poor urban neighborhoods while suburban populations exploded. ${ }^{16}$ Given that prosecutors and judges are typically elected at the county level, while police are a city institution, this means suburban and wealthy urban voters now had relatively more power over urban criminal justice. ${ }^{17}$ These voters, however, enjoying historically low crime rates following World War II, had little reason to care about local criminal justice, and everyday policing and prosecution became the job of often-distant technocrats. 18 "These professionals and experts," Stuntz laments, "changed the justice system almost entirely for the worse." 19 The upshot: the mostly black residents of today's poor city neighborhoods, where crime rates are highest, "have less ability than in the past to govern the police officers and prosecutors who govern them." ${ }^{20}$ And "[a]s local democracy has faded ... discrimination has grown more common, and criminal punishment has become prone to extremes." 21

The solution, urges Stuntz, is to reverse course. "If criminal justice is to grow more just," Stuntz reasons, "those who bear the costs of crime and punishment alike must exercise more power over those who enforce the law and dole out punishment."22 "Make criminal justice more locally democratic," the argument goes, "and justice will be more moderate, more egalitarian, and more effective at controlling crime." 23 What we need is "a large dose of the local democracy that once ruled American criminal justice." ${ }^{24}$

Bill Stuntz, in Michael J. Klarman, David A. Skeel, and Carol S. Steiker, eds, The Political Heart of Criminal Procedure: Essays on Themes of William J. Stuntz 87, 88, 93, 98-101 (Cambridge 2012). Sklansky called Stuntz the "Charles Dickens of criminal procedure scholars"- "everyone wanted [him] as an ally and everyone saw in him a sympathetic soul." Id at 87.

15 William J. Stuntz, The Collapse of American Criminal Justice 2 (Belknap 2011).

16 Id at $7,16-22,35$.

17 Id at 35 .

18 Id at 7, 193.

19 Stuntz, Collapse of American Criminal Justice at 194 (cited in note 15).

20 Id at 7.

21 Id.

22 Id.

23 Stuntz, Collapse of American Criminal Justice at 39 (cited in note 15).

24 Id at 8. 
Community policing, for Stuntz, is a promising start; better yet would be "more jury trials in order to give local citizens ... the power to decide who merits punishment and who doesn't." ${ }_{25}$

An expanding literature supplies numerous consonant accounts. What unites them is a conviction that the "root of the present crisis," in Professor Josh Kleinfeld's phrasing, "is a set of bureaucratic attitudes, structures, and incentives divorced from the American public's concerns and sense of justice."26 The prescription, in turn, is complementary: "[M]ake criminal justice more community focused and responsive to lay influences." 27 The cast of "democratizers" reads like a who's who of contemporary criminal justice scholars representing a range of methodological and ideological perspectives-momentum has only grown in the decade since Sklansky called the preference for democracy over expertise "the general view among scholars today." 28 Stuntz and Kleinfeld's fellow travelers include, to varying degrees, nowJudge Stephanos Bibas, as well as Professors Laura Appleman, Rick Bierschbach, Josh Bowers, Robert Burns, Adriaan Lanni, Tracey Meares, Janice Nadler, Paul Robinson, Dorothy Roberts, Jonathan Simon, Jocelyn Simonson, and Tom Tyler, among others. There is now a democratization "manifesto" and a groupauthored white paper of detailed policy proposals. ${ }^{29}$

This Article's claim is that we follow this path of "democratization" at considerable peril. As a rhetorical weapon, "democratic criminal justice" has undeniable power, if sometimes troubling imprecision. Were scholarship but a battle of rhetoric, I would contemplate surrender. Who, after all, could be against democracy? ${ }^{30}$ In fact, my sympathy for the democratization position runs deeper still-I wish we lived in a world in which the democratizers' plans would work. Yet, as political scientist Robert Dahl cautioned, "There is a great variety of empirical facts that one needs to know . . . before one can rationally decide on the kinds of

25 Id.

26 Kleinfeld, $111 \mathrm{Nw}$ U L Rev at 1376 (cited in note 14).

27 Id.

28 See Sklansky, Democracy and the Police at $230 \mathrm{n} 81$ (cited in note 13).

29 Kleinfeld, 111 Nw U L Rev at 1376-77 (cited in note 14). See also generally Joshua Kleinfeld, et al, White Paper of Democratic Criminal Justice, 111 Nw U L Rev 1693 (2017).

30 On the rhetorical power of the democratic ideal, see Robert A. Dahl, Who Governs? Democracy and Power in an American City 317 (Yale 1961) ("To reject the democratic creed is in effect to refuse to be an American."); James A. Stimson, Tides of Consent: How Public Opinion Shapes American Politics 170 (Cambridge 2004) ("The word 'democracy' is bound up with symbolism, belief, patriotism, and a quasi-religious commitment.”). 
political rules one wants to follow in the real world." 31 My concern is that the pertinent empirical facts do not favor the democratizers' designs. This skepticism is grounded in social scientific research-drawn from political science, psychology, sociology, economics, criminology, and empirical legal studies-about public attitudes toward punishment, racial bias, judicial behavior, group decision-making, and more. The democratizers overlook or minimize much of this work, emphasizing theoretical arguments and, on central issues, a surprisingly small number of empirical studies they claim favor their position. When all the evidence is fairly weighed, the argument for more participatory democracy becomes significantly harder to sustain, at least if the goal is a better criminal justice system rather than participation for its own sake.

I begin, in Part I, by describing and organizing the democratization literature. This requires interweaving myriad scholarly works by creative and independent-minded authors, some of whom might resist being lumped together or disagree with portions of the democratization agenda. ${ }^{32}$ Yet any slight overgeneralization is justified by the important shared assumptions it reveals. I am indebted here to Kleinfeld, whose sweeping pro-democratization "manifesto" helped me organize my own thinking. Kleinfeld rightly acknowledges "a range of opinion within the democratization movement on the degree to which criminal justice should be open to ... popular-majoritarian control." 33 Yet democratization is also a "big tent movement"- to be a member, "it is enough to think the arrow of reform points toward more democracy," as the

31 Robert A. Dahl, A Preface to Democratic Theory 52 (Chicago 1956). See also Brian Leiter, The Roles of Judges in Democracies: A Realistic View *6-16 (University of Chicago Public Law \& Legal Theory Paper Series No 622, Mar 17, 2017), archived at https://perma.cc/QQ3V-TTDT (describing a "realistic view of democracy"). See generally Christopher H. Achen and Larry M. Bartels, Democracy for Realists: Why Elections Do Not Produce Responsive Government (Princeton 2016) (arguing that folk theories of democracy collapse in the face of social scientific evidence about the behavior of democratic citizens).

32 See, for example, Josh Bowers, Upside-Down Juries, 111 Nw U L Rev 1655, 166566 (2017) ("I do not prize popular participation qua participation."); Tracey Meares, Policing and Procedural Justice: Shaping Citizens' Identities to Increase Democratic Participation, $111 \mathrm{Nw}$ U L Rev 1525, 1526 (2017) ("I think I am more of a fan of bureaucracy than the organizers of this [democratization] Symposium may be."); Dorothy E. Roberts, Democratizing Criminal Law as an Abolitionist Project, 111 Nw U L Rev 1597, 1604 (2017) (critiquing the procedural justice aspect of democratization); Jocelyn Simonson, Democratizing Criminal Justice Through Contestation and Resistance, 111 Nw U L Rev 1609, 1611 (2017) ("Relying on deliberation and consensus ignores the ways in which our current criminal justice system relegates African-Americans and other marginalized populations to non-democratic subjects.").

33 Kleinfeld, $111 \mathrm{Nw}$ U L Rev at 1399-1400 (cited in note 14). 
democratizers define it, "not less." ${ }^{44}$ Indeed, the nineteen authors of the democratization white paper insist that their views, while not identical, "do not vary so much as to undermine the distinctiveness of [their] identity as a school of thought in criminal law and procedure and a movement in criminal justice reform." ${ }^{35}$

In unpacking the democratization literature, it helps to distinguish among democratization's principles, purposes, and concrete proposals. Democratization's principles feature a commitment to widespread lay participation in criminal justice and an aversion to bureaucratic and expert control. "The idea that crime should be kept out of public life," the democratizers think, "safely handled by a coterie of experts, was and remains profoundly antidemocratic." 36

Democratization's purposes begin with attacking the criminal justice system's "twin problems": severity and inequality. Amplifying the laity's voice, meanwhile, and aligning the criminal law with community values, will boost the law's legitimacy, or moral credibility, promoting respect and compliance-in turn, one hopes, permitting even greater leniency. Finally, the democratizers pursue a constellation of benefits intrinsic to participation itself. Some of these sound in nonconsequentialist terms, such as the simple satisfaction of a community's desire to participate. Others are rooted in consequentialist grounds ancillary to criminal justice: participation promotes engagement in civic life and builds social capital.

Next are the democratizers' discrete policy proposals, which can be loosely sorted into four groups. The first contains diverse recommendations for substantive law reform, like downgrading offense levels and thinning the criminal code. Proposals in the second group involve altering structural incentives to temper policing and prosecution and promote procedural justice, such as by forcing localities to internalize the fiscal costs of punishment and evaluating the police on measures that reflect community trust. The third group envisions citizen advisory and oversight committees working alongside legislatures, police, prosecutors, and corrections officials. The final cluster concerns jury reform: moreand more representative-juries, not just for guilt determination but also charging, bail, plea bargaining, and sentencing.

34 Id at 1400 .

35 Kleinfeld, et al, $111 \mathrm{Nw}$ U L Rev at 1697 (cited in note 29).

36 Ian Loader, Fall of the 'Platonic Guardians': Liberalism, Criminology, and Political Responses to Crime in England and Wales, 46 Brit J Crimin 561, 582 (2006). 
I will not be quite ready, after laying all of this out, to pivot from description to critique. For my objection is not to the democratizers' principles and proposals in the abstract, or to their purposes, which I generally support. My objection instead concerns what I take to be their fundamental premises: the empirical facts that must be true for their principles-and the proposals designed to implement them-to achieve their intended purposes. My objection, in other words, is not to participatory democracy writ large, but rather to whether the mechanisms of participatory democracy the democratizers propose will yield the criminal justice outcomes they claim to desire.

The last task of Part I, then, is to elaborate these premises. The democratization project, I argue, requires that: (1) people reside in cohesive communities that are able-in fact, yearn-to express collective values about criminal justice; (2) people are relatively lenient, at least toward their own community members; (3) the bureaucracy is comparatively more severe; (4) people are egalitarian, at least, again, toward their neighbors and friends; and (5) giving people voice, and aligning the law with community values, will bolster the legitimacy and moral credibility of the system, leading to better law compliance and cooperation with authorities.

These premises are simple enough to state but-perhaps because we (all of us) want them to be true-rebutting them requires extensive argument. That is the task of Part II, the Article's heart. The democratization position, I argue, rests on conceptually problematic and empirically dubious premises about the existence, makeup, preferences, and independence of local "communities" and ignores the ways in which deliberative mechanisms tend to amplify predictably dominant voices. It does not fairly weigh the evidence on public attitudes toward punishment, the political economy of sentencing, or the benefits insulated bureaucratic institutions can provide. It naively assumes that people will go easy on "their own" despite considerable contrary evidence. And it exaggerates the empirical case for inducing compliance through procedural justice and empirical desert techniques.

The very possibility that democratization might not deliver what it aims to accomplish exposes the fragility of the democratizers' big-tent coalition. The democratizers purport to commit simultaneously to principles (means) and purposes (ends) they believe those principles will promote. What happens if, as my evidence suggests, the means do not produce the ends? The movement will surely splinter. On one side will be those committed to 
the principles of lay participation, wherever they may lead. Such a philosophy is their prerogative, of course, but they are disingenuous to wrap themselves in the rhetoric of the resistance. On the other side will be those committed to decarceration, however accomplished. Their belief in democratization is shallow and contingent; they do not wish to effectuate community values that conflict with their own reform prescriptions. The people matter only insofar as they provide strategic cover for, and legitimation of, what is ultimately an expert-driven agenda.

Part III, the conclusion, gestures toward alternative visions of "democratic" criminal justice, some of which unabashedly seek to emphasize expert perspectives. Actually, many of the democratizers' own proposals are not only consistent with top-down, expert-driven reforms, but also are more plausibly viewed as such. This is not a criticism, to my mind. Indeed, one of democratization's shortcomings may be that it obscures the potential of additional such improvements to the system. That being said, practical constraints prevent the elaboration of a well-specified alternative model of reform, and Part III endeavors only to illuminate a few plausible directions.

Many readers will already have observed that these are, in a sense, old battles being refought. The conflict between lay and expert governance is as old as democracy itself, 37 and domestically predates the Founding. (Just ask Alexander Hamilton. ${ }^{38}$ ) Even within criminal justice circles, the pendulum has been swinging for decades. Early reformers professionalized criminal justice institutions to address one set of problems and, when crime rates climbed in the 1970s and 1980s, were blamed for another. Politics then pried control from expert hands. ${ }^{39}$ Academics, in turn, forcefully criticized this populist shift, which generated a raft of deeply punitive policies like "three-strikes" laws. ${ }^{40}$ And now the democratizers present an academic defense of populist criminal justice

37 See Ilya Somin, Democracy and Political Ignorance: Why Smaller Government Is Smarter 7-9 (Stanford Law 2d ed 2016) (summarizing debates over lay political ignorance beginning with Plato and Aristotle).

38 Max Farrand, ed, 1 The Records of the Federal Convention of 1787299 (Yale 1911) (remarks of Alexander Hamilton) ("The voice of the people has been said to be the voice of God; and however generally this maxim has been quoted and believed, it is not true in fact.").

39 See David Garland, The Culture of Control: Crime and Social Order in Contemporary Society 13 (Chicago 2001).

40 See generally, for example, Michael Tonry, Thinking About Crime: Sense and Sensibility in American Penal Culture (Oxford 2004); Julian V. Roberts, et al, Penal Populism and Popular Opinion: Lessons from Five Countries (Oxford 2003); Franklin E. Zimring, 
alongside a platform for refined, and even more far-reaching, changes.

My intervention does not simply repeat the last generation's critique of populist criminal justice policies, though certainly I benefit from their labor. My target is not the political realm but specifically the intellectual framework the democratizers have erected to justify the investment of power in the laity. In addition, the body of social science evidence that bears on these questions has ballooned in the past two decades or so. I respond, in other words, to arguments that were largely unarticulated, with evidence that was mostly unavailable, when the previous generation wrote. ${ }^{41}$

If it is true, as many say, that we are in the midst of a criminal justice "moment," when extraordinary reform may be possible, it is essential to scrutinize the evidence that bears on what kind of democracy we ought to demand in the criminal justice domain. Participatory and deliberative democracy are gathering momentum as potential answers to this crucial question. This Article seeks to pump the brakes and initiate a more nuanced conversation about where that will really lead.

\section{THE CASE FOR DEMOCRATIZATION}

This Part synthesizes and structures the democratization project. Part I.A identifies the democratizers' core principles and situates them within broader debates about the nature of democracy writ large. It also explains how democratization relates to localism. Part I.B explains the democratizers' purposes. Part I.C walks through their concrete policy proposals. Finally, Part I.D extracts the central premises that support the democratization agenda. The democratizers are less explicit about some of these

Gordon Hawkins, and Sam Kamin, Punishment and Democracy: Three Strikes and You're Out in California (Oxford 2001).

41 The closest account may be Sklansky's treatment of the relationship between democratic theory and policing. Sklansky draws upon insights from the "democratic pluralists" to identify blind spots in contemporary thinking about democratic policing. These insights, which echo throughout this Article, include the "dangers of assuming a unified public; the grounds for skepticism about the feasibility, necessity, and desirability of universal political engagement ... and the democratic attractions of modernity." Sklansky, Democracy and the Police 108 (cited in note 13). Similar themes appear in Professor Rachel Barkow's recent book. See generally Rachel Elise Barkow, Prisoners of Politics: Breaking the Cycle of Mass Incarceration (Belknap 2019). 
premises than others. Nevertheless, here, as throughout the Article, I prioritize fidelity to the democratizers' own expressed views, while necessarily eliding distinctions to some extent.

\section{A. Principles}

The democratization project aims to increase opportunities for ordinary citizens to participate in, deliberate about, and ultimately influence criminal justice policymaking and adjudication. In this sense, the "democratization" label is unfortunately vague-democracy is, as the democratizers acknowledge, "a profoundly contested concept." 42 Yet the democratizers have something quite specific in mind: to infuse criminal justice not just with "democracy" in some general sense, but with deliberative and participatory democracy. These traditions "insist, as their names imply, on the importance of the broader political community's deliberation on matters of public concern and participation in the activity of government." 43

Voting is one form of lay participation. Professor Kleinfeld, for example, emphasizes the "absolutely central place of voting in all democracy as such." 44 Nevertheless, representative democracy is clearly too weak to quench the democratizers' democratic thirst. They criticize "skeptical, minimalist" conceptions of democracy that consist "essentially in choosing which set of elites rules at a given time." 45 Yet they are even more distrustful of arrangements that would keep important issues from the voters and bureaucrats who are insulated from public accountability. ${ }^{46}$

The democratizers also believe in downsizing the role of criminal justice bureaucrats and experts. ${ }^{47}$ While there are, of course,

42 Kleinfeld, $111 \mathrm{Nw} \mathrm{U} \mathrm{L} \mathrm{Rev} \mathrm{at} 1378$ (cited in note 14). This is a major theme of Sklansky's work on democratic policing and prosecution. See Sklansky, Democracy and the Police at 108 (cited in note 13); David Alan Sklansky, Unpacking the Relationship Between Prosecutors and Democracy in the United States, in Máximo Langer and David Alan Sklansky, eds, Prosecutors and Democracy: A Cross-National Study 276, 283-86 (Cambridge 2017).

43 Kleinfeld, $111 \mathrm{Nw} \mathrm{U}$ L Rev at 1378 (cited in note 14).

44 Id at 1394.

45 Id at 1383-84, discussing Joseph A. Schumpeter, Capitalism, Socialism and Democracy 252-53 (Routledge 5th ed 2003).

46 See, for example, Bibas, Machinery of Criminal Justice at xxi (cited in note 12) (arguing that the ability of legal insiders to operate independently from the public's interest and without its full understanding "subverts democracy").

47 See, for example, id at 105 (criticizing "expert-worship"); id at 129 (lamenting the criminal justice system's "legalese and mathematical gobbledygook"). There are some exceptions. Professor Meares, in particular, has advocated greater use of empiricism and 
ways for the laity and bureaucracy to collaborate, decisional influence is at bottom a zero-sum game. The democratizers see themselves as reversing a trend in which lawyers and experts have "stolen" the criminal law-and the community morality it embodies-from the people, and replaced it with a "scientific language of efficiency and deterrence." 48 The democratizers do not generally maintain that experts are evil or ill-intentioned. Experts are more often portrayed as indifferent (homo economicus in pursuit of a promotion and leisure time) or well-meaning but misguided (Warren Court justices, in Stuntz's famous account, who set out to protect the downtrodden but ended up making things worse). ${ }^{49}$ Either way, the democratizers offer a deeply skeptical take on a privileged cadre who think they know best but, in reality, lack the passion, personal investment, and local wisdom of the people themselves. ${ }^{50}$

Finally, democratization is entangled, in application, with localism, a distinct but overlapping theory about how to organize state power in a federal system. ${ }^{51}$ In the abstract, one can envision a local, expert-driven bureaucracy or participatory democracy on a large scale, such as a statewide referendum. That said, for a host of reasons, the democratizers focus on the local level, where populist reform is most likely to gain traction. ${ }^{52}$ Accordingly, I will frequently refer to "local democracy" or participatory "community justice" not because the concepts are analytically linked but because they run together in practice.

As should now be evident, I will not address all arguments about the relationship between democracy (of whatever sort) and

social science research in criminal procedure. See, for example, Tracey Meares and Tom Tyler, Policing: A Model for the Twenty-First Century, in Angela J. Davis, ed, Policing the Black Man: Arrest, Prosecution, and Imprisonment 161, 173 (Pantheon 2017).

48 Bibas, Machinery of Criminal Justice at xxiv, 86 (cited in note 12). See also Nils Christie, Conflicts as Property, 17 Brit J Crimin 1, 3-5 (1977).

49 See Stuntz, Collapse of American Criminal Justice at 216-43 (cited in note 15).

50 The democratizers insist they are not radicals, and resist only the system's complete bureaucratization. See, for example, Bibas, Machinery of Criminal Justice at xxv (cited in note 12); Kleinfeld, $111 \mathrm{Nw} \mathrm{U} \mathrm{L} \mathrm{Rev} \mathrm{at} 1381$ (cited in note 14). However, their rhetoric consistently suggests a more ambitious program. After all, no one is arguing for total bureaucratization, so far as I am aware.

51 For a helpful explication of the relationship between democratization and localism, with focus on the latter, see generally Elizabeth Jánszky, Note, Defining the "Local" in a Localized Criminal Justice System, 94 NYU L Rev 1318 (2019).

52 Bibas, Machinery of Criminal Justice at xxvi (cited in note 12). See also Stuntz, Collapse of American Criminal Justice at 283 (cited in note 15) (asserting that "[t]he keys to useful reform" include "decentralization [and] local democracy"). 
criminal justice. I am not focused here, for example, on the troubling effects of criminal justice on democracy - the ways in which the system undermines self-governance by excluding millions of Americans from the democratic process and civic life more generally. ${ }^{53}$ My topic is the arrow that runs in the other direction: the effects of democracy-deliberative and participatory democracy, in particular-on criminal justice. The two may be related, of course: a more inclusive polity might, through democratic participation, produce a better system than the polity that governs today. This does require certain assumptions, not clearly supported by the available evidence, ${ }^{54}$ about the ways in which these currently excluded individuals would contribute. In any event, my approach will be to take the polity as I find it and examine how it would, if empowered in the ways the democratizers envision, shape criminal justice, and not the other way around.

\section{B. Purposes}

What, exactly, the democratizers aim to accomplish varies across scholarly accounts. Yet four principal purposes cover most of the terrain. The first two are simply stated: the democratizers hope to reduce mass incarceration and mitigate racial disparity in the administration of criminal justice. ${ }^{55}$ Again, particulars vary - concern about mass incarceration, for example, can encompass sentencing, overcriminalization, prosecutorial power, policing, and even prison conditions. But a clear through-line emerges in these accounts: the democratizers aim to make the system less harsh and less discriminatory.

53 See generally Amy E. Lerman and Vesla M. Weaver, Arresting Citizenship: The Democratic Consequences of American Crime Control (Chicago 2014); Bell, 126 Yale L J 2054 (cited in note 11).

54 See, for example, James M. Binnall, A Field Study of the Presumptively Biased: Is There Empirical Support for Excluding Convicted Felons from Jury Service?, 36 L \& Pol 1, 15-16 (2014) (finding that convicted felons, on average, exhibit a prodefense bias, but not greater than that of law students); Thomas J. Miles, Felon Disenfranchisement and Voter Turnout, 33 J Legal Stud 85, 85 (2004) (finding that felon disenfranchisement has "no discernible effect on state-level rates of voter turnout").

55 See, for example, Albert W. Dzur, Participatory Democracy and Criminal Justice, 6 Crim L \& Phil 115, 115 (2012) (asking whether there is a "role for an active public in ratcheting down the tough-minded politics of crime control in the United States"); Adriaan Lanni, Implementing the Neighborhood Grand Jury, in Roger Anthony Fairfax Jr, ed, Grand Jury 2.0: Modern Perspectives on the Grand Jury 171, 172 (Carolina Academic 2011) ("[P]ermitting local community members to play an active role in prosecutorial charging decisions and policies would help alleviate some of the political pathologies that have led to mass incarceration and the crisis of legitimacy."). 
The third purpose concerns the law's moral authority. Largely because the criminal justice system is too harsh and too discriminatory, Stuntz observes, it "strikes many of its targets as wildly unjust." 56 Judge Bibas blames bureaucratization directly for the system's legitimacy deficit. He points to plea bargaining and other "trends that have professionalized and mechanized the criminal justice system so much that it is out of touch with ordinary people's expectations and desires." 57 The democratizers offer their program partly to remedy this problem. The underlying motivation, for many democratizers, is instrumental: legitimacy promotes compliance with the law-crime control—and cooperation and engagement with authorities. ${ }^{58}$

The fourth and final purpose is largely ancillary to the other three. It involves a constellation of benefits thought to inhere in participation itself. At times, these aims take on a nonconsequentialist cast. In describing deliberative democracy, Kleinfeld asserts that the "end is to ensure that the individuals who comprise society can participate in 'democratic opinion- and willformation,' and that government has to listen once the democratic opinion and will are formed." 59 This requires no "exaggerated faith," Kleinfeld adds, in "the likelihood that deliberative processes will reach true or best substantive conclusions." 60 It is simply that "law and other exercises of governmental power should reflect and respond to the ethical life of the people living under that law and government." ${ }_{1}$

There are consequentialist, if not criminal-justice-related, reasons to value lay participation as well. Participation educates and promotes engagement in civic life. ${ }^{62}$ It may strengthen community and dampen public conflict. ${ }^{63}$ The jury, in particular,

56 Stuntz, Collapse of American Criminal Justice at 2 (cited in note 15).

57 Bibas, Machinery of Criminal Justice at xvii (cited in note 12).

58 See Kleinfeld, $111 \mathrm{Nw}$ U L Rev at 1406 (cited in note 14) ("What the empirics essentially show is that controlling the crime rate is impossible without normative buy-in from the community.").

59 Id at 1385, quoting Jürgen Habermas, Between Facts and Norms 300 (MIT 1996) (citation omitted) (emphasis added) (William Rehg, trans).

60 Kleinfeld, $111 \mathrm{Nw}$ U L Rev at 1386-87 (cited in note 14).

61 Joshua Kleinfeld, Three Principles of Democratic Criminal Justice, $111 \mathrm{Nw}$ U L Rev 1455, 1466 (2017).

62 See Benjamin R. Barber, Strong Democracy: Participatory Politics for a New Age 235-36 (California 1984); John Dewey, The Public and Its Problems 148-49 (Henry Holt 1927); Carole Pateman, Participation and Democratic Theory 45 (Cambridge 1970).

63 See Barber, Strong Democracy at 152-53 (cited in note 62); David Mathews, Politics for People: Finding a Responsible Public Voice 40-41 (Illinois 1994). 
Alexis de Tocqueville famously wrote, is "one of the most efficacious means for the education of the people which society can employ." 64 Contemporary social science research suggests de Tocqueville may have been onto something: people who deliberate on juries subsequently may be more likely to vote, follow politics, and get involved in political groups. ${ }^{65}$

\section{Proposals}

Over the years, the democratizers have generated scores of specific reform proposals. Conveniently for my purposes, a group of nineteen scholars recently issued a White Paper of Democratic Criminal Justice enumerating thirty concrete ideas. ${ }^{66}$ I quote generously from this white paper here, though I impose my own organization and cite additional sources consonant with the democratizers' ideas.

The proposals can be usefully sorted into four groups. The first contains suggestions for substantive law reform, including the law of punishment. Some examples: laws and practices "that violate community views of justice . . should be eliminated";67 "[n]oncriminal approaches to social problems should be favored";68 "[t]he use of the legal category of 'felony' should be greatly reduced"; 69 "[p]enal codes should be recodified to eliminate overlap among offenses"; "the minimum and maximum limits of punishment should be based on ... community standards"; "r1 "reliance on probation and surveillance should be reduced"; 72 "[c]onditions in prisons and other correctional facilities should

64 Alexis de Tocqueville, 1 Democracy in America 306 (D. Appleton \& Co 1904) (Henry Reeve, trans) (originally published 1835). See also Akhil Reed Amar, The Bill of Rights: Creation and Reconstruction 113 (Yale 1998); Heather K. Gerken, Second-Order Diversity, 118 Harv L Rev 1099, 1144-45 (2005); John Stuart Mill, Considerations on Representative Government, in John M. Robson, ed, 19 The Collected Works of John Stuart Mill 371, 41112 (Toronto 1977).

65 See generally John Gastil, et al, The Jury and Democracy: How Jury Deliberation Promotes Civic Engagement and Political Participation (Oxford 2010).

66 See generally Kleinfeld, et al, $111 \mathrm{Nw}$ U L Rev 1693 (cited in note 29).

67 Id at 1697. See also generally Paul H. Robinson and John M. Darley, Justice, Liability, and Blame: Community Views and the Criminal Law (Westview 1995); Joshua Kleinfeld, Reconstructivism: The Place of Criminal Law in Ethical Life, 129 Harv L Rev 1485 (2016).

68 Kleinfeld, et al, $111 \mathrm{Nw}$ U L Rev at 1698 (cited in note 29).

69 Id.

70 Id at 1699 .

71 Id at 1703. See also Bibas, Machinery of Criminal Justice at 132 (cited in note 12).

72 Kleinfeld, et al, $111 \mathrm{Nw}$ U L Rev at 1703 (cited in note 29). 
be . . non-criminogenic"; 73 "all collateral consequences that impair . . . people from rejoining society . . should be abolished"; ${ }^{74}$ and "[j]udges should broadly . . . uphold and enforce the principle of equal citizenship throughout criminal justice." ${ }^{75}$

Proposals in the second group would modify criminal justice institutions to create incentives for better policing and prosecution. "Police practices and a police culture consistent with norms of procedural justice ... should be fostered," such as by "recruiting officers with ... links to the communities they police" and "evaluating officers and departments based on metrics that reflect community trust." ${ }^{76}$ "Public defenders and prosecutors should enjoy commensurate resources"; ${ }^{77}$ "[p]rosecutors [should] shadow public defenders" and vice versa;78 "jurisdictional boundaries of prosecutorial offices should be redrawn to make prosecutors . . responsive to smaller and more cohesive communities"; 79 and "[t]he county or other political unit with the authority to decide ... to prosecute or sentence an individual should also bear the financial costs of prosecuting or carrying out the sentence." 80

The third set of proposals entails the creation of citizen advisory and oversight committees: "[a]dvisory committees to aid legislatures in the process of crafting substantive and procedural criminal law should be established" and "should include a diverse mixture of lay citizens, community leaders, judges, prosecutors, public defenders, private criminal justice attorneys, police officers, criminal justice scholars, and other stakeholders and experts in criminal justice"; 81 "[c]ivilian review boards . . should be established," permitting a diverse group of locals to advise police departments on "priorities, policies, and informal practices, as

73 Id.

74 Id at 1704 .

75 Id at 1698. See also Stuntz, The Collapse of American Criminal Justice at 291 (cited in note 15).

76 Kleinfeld, et al, $111 \mathrm{Nw}$ U L Rev at 1699 (cited in note 29).

77 Id at 1700.

78 Id. See also Jed S. Rakoff, Why Prosecutors Rule the Criminal Justice Systemand What Can Be Done About It, 111 Nw U L Rev 1429, 1435-36 (2017) (proposing that prosecutors occasionally serve as defense counsel).

79 Kleinfeld, et al, $111 \mathrm{Nw}$ U L Rev at 1702 (cited in note 29). See also Ronald F. Wright, Elected Prosecutors and Police Accountability, in Davis, ed, Policing the Black Man 234, 234-41 (cited in note 47).

80 Kleinfeld, et al, $111 \mathrm{Nw}$ U L Rev at 1705 (cited in note 29). See also Stuntz, Collapse of American Criminal Justice at 289 (cited in note 15).

81 Kleinfeld, et al, $111 \mathrm{Nw}$ U L Rev at 1699 (cited in note 29). 
well as disciplinary decisions involving individual officers"; 82 collaboration between prosecutors and communities should be encouraged; 83 "[r]estorative justice institutions and proceedings should be established"; 84 and "the local community should be involved in ... citizen oversight boards for matters of policy and conditions in jails, prisons, and other correctional facilities." ${ }^{5}$

Finally, the democratizers want juries-more juries, with more information and authority, in more spaces, and more representative of the local communities from which they are drawn. ${ }^{86}$ Specifically, "[g]rand juries should . . . engage in genuine and substantial supervision of prosecutors' charging decisions"; 87 "bail juries" should be established; 88 "[p]ractices of plea bargaining should be modified to give juries meaningful supervisory authority"; 89 "[t]he trial jury . . . should be informed of its right to make judgments of both fact and law and to acquit based on an overall

82 Id at 1700 . This essentially describes community policing, which has spawned a literature too vast even to sample and much of which is growing dated. For one recent intervention, see generally John M. Ray, Rethinking Community Policing (LFB Scholarly 2014). On disciplinary civilian review boards, in particular, see generally Debra Livingston, The Unfulfilled Promise of Citizen Review, 1 Ohio St J Crim L 653 (2004).

83 On community prosecution, see generally Anthony V. Alfieri, Community Prosecutors, 90 Cal L Rev 1465 (2002); Bruce A. Green and Alafair S. Burke, The Community Prosecutor: Questions of Professional Discretion, 47 Wake Forest L Rev 285 (2012).

84 Kleinfeld, et al, $111 \mathrm{Nw}$ U L Rev at 1703 (cited in note 29). See also generally John Braithwaite, Criminal Justice That Revives Republican Democracy, $111 \mathrm{Nw}$ U L Rev 1507 (2017).

85 Kleinfeld, et al, $111 \mathrm{Nw}$ U L Rev at 1705 (cited in note 29).

86 See, for example, Stuntz, Collapse of American Criminal Justice at 302-04 (cited in note 15). See generally Laura I. Appleman, Defending the Jury: Crime, Community, and the Constitution (Cambridge 2015); Suja A. Thomas, The Missing American Jury: Restoring the Fundamental Constitutional Role of the Criminal, Civil, and Grand Juries (Cambridge 2016). But see Meares, 111 Nw U L Rev at 1526 n 2 (cited in note 32) ("I do not favor incorporating citizen decisionmaking into all aspects of criminal adjudication, such as bail hearings, guilty pleas, and sentencing decisions.").

87 Kleinfeld, et al, $111 \mathrm{Nw}$ U L Rev at 1700 (cited in note 29). See also generally Josh Bowers, The Normative Case for Normative Grand Juries, 47 Wake Forest L Rev 319 (2012). See also Adriaan Lanni, The Future of Community Justice, 40 Harv CR-CL L Rev 359, 396-99 (2005).

88 Kleinfeld, et al, $111 \mathrm{Nw}$ U L Rev at 1705 (cited in note 29). See also Laura I. Appleman, Justice in the Shadowlands: Pretrial Detention, Punishment, and the Sixth Amendment, 69 Wash \& Lee L Rev 1297, 1363-69 (2012).

89 Kleinfeld, et al, $111 \mathrm{Nw}$ U L Rev at 1697 (cited in note 29). See also generally Laura I. Appleman, The Plea Jury, 85 Ind L J 731 (2010). See also Stephanos Bibas and Richard A. Bierschbach, Integrating Remorse and Apology into Criminal Procedure, 114 Yale L J 85, 141, 144 (2004); Jason Mazzone, The Waiver Paradox, 97 Nw U L Rev 801, 872-78 (2003). 
equitable judgment"90 and "of the sentencing implications and related consequences of a finding of guilt"; 91 and "[s]entencing juries should be generally established and empowered to decide ultimate sentences or other dispositions of a case." 92 For all juries, "[p]ractices of excluding citizens ... based on their attitudes toward or histories with the criminal justice system ... should be reduced in favor of a presumption of random selection and inclusion." 93

\section{Premises}

For the democratization project to hold together, its adherents must believe the reforms they propose will serve the purposes that motivate their scholarly efforts. This Section probes the democratizers' beliefs by extracting five supporting premises from the democratization literature and summarizing the evidence for each. These five premises, rather than the democratizers' abstract principles or proposals, are the focus of Part II's critical attention.

\section{Community.}

The concept of "community" is central to the democratization agenda. Indeed, the whole point of democratization, on one telling, is to "make criminal justice more community focused." ${ }_{94}$ In service of this aim, laws and practices inconsistent with "community views of justice" are to be jettisoned. ${ }^{95}$ Legislative advisory committees should feature "community leaders." 96 Peace officers

90 Kleinfeld, et al, $111 \mathrm{Nw}$ U L Rev at 1701 (cited in note 29). See also, for example, Stuntz, Collapse of American Criminal Justice at 303-04 (cited in note 15). See also generally, for example, Paul Butler, Racially Based Jury Nullification: Black Power in the Criminal Justice System, 105 Yale L J 677 (1995).

91 Kleinfeld, et al, $111 \mathrm{Nw}$ U L Rev at 1704 (cited in note 29).

92 Id at 1705. See also, for example, Rachel E. Barkow, Recharging the Jury: The Criminal Jury's Constitutional Role in an Era of Mandatory Sentencing, 152 U Pa L Rev 33, 102-16 (2003); Bibas, Machinery of Criminal Justice at 156-64 (cited in note 12) (advocating for "restorative sentencing juries"). On jury sentencing, see generally Morris B. Hoffman, The Case for Jury Sentencing, 52 Duke L J 951 (2003); Jenia Iontcheva, Jury Sentencing as Democratic Practice, 89 Va L Rev 311 (2003); Adriaan Lanni, Note, Jury Sentencing in Noncapital Cases: An Idea Whose Time Has Come (Again)?, 108 Yale L J 1775 (1999). But see Paul H. Robinson, Democratizing Criminal Law: Feasibility, Utility, and the Challenge of Social Change, $111 \mathrm{Nw}$ U L Rev 1565, 1594 (2017) ("[T] he proper place of community views is in the creation of legal rules, not in the adjudication of individual cases.").

93 Kleinfeld, et al, $111 \mathrm{Nw}$ U L Rev at 1697 (cited in note 29).

94 Kleinfeld, $111 \mathrm{Nw}$ U L Rev at 1376 (cited in note 14).

95 Kleinfeld, et al, $111 \mathrm{Nw}$ U L Rev at 1697 (cited in note 29).

96 Id at 1699. 
should be recruited from the "communities they police." 97 Community policing and prosecution should be encouraged. "[P]unishment that ... undermine[s] the community's values" should be rejected. ${ }^{98}$ And imprisonment should be used "only to the extent the crime in view was a serious one according to community views of justice."99

Fashioning community "views" and "values" as policy benchmarks presumes the existence of these collective sentiments. 100 The democratizers recognize that today's communities are more heterogeneous and loosely stitched than those of the past. ${ }^{101}$ Still, empirical research by Professor Paul Robinson and others finds that, despite "pockets of disagreement," today's "[o]rdinary citizens share a robust consensus about the substantive wrongfulness of various crimes" - that is, "which acts are wrongful and how wrongful they are relative to other crimes." 102 "Much of the apparent disagreement on crime and punishment," this research suggests, "is an artifact of our abstract, politicized process," which allows listeners to fill in vastly varying specifics. ${ }^{103}$ "People show remarkable agreement on most crimes," in contrast, "when given detailed, concrete factual scenarios." 104 People also widely agree on procedural matters-specifically, on what makes procedures fair. ${ }^{105}$

The democratizers tend to reject, moreover-as "too pessimistic"-the view that "many places in America no longer have any meaningful sense of community on which criminal justice can

97 Id.

98 Id at 1702.

99 Kleinfeld, et al, 111 Nw U L Rev at 1703 (cited in note 29).

100 As Sklansky observes in the context of community policing, the notion here is that there is, "in any particular polity, an identifiable 'public' or 'community' position on controversial policy questions, embraced by ordinary citizens as well as political leaders, and rising above the narrow interests of particular groups." Sklansky, Democracy and the Police at 87 (cited in note 13). These assumptions resemble those regularly made in communitarian theories of democracy. See, for example, Alan F. Kay, Locating Consensus for Democracy: A Ten-Year U.S. Experiment 9 (Americans Talk Issues 1998).

101 See, for example, Bibas, Machinery of Criminal Justice at 117 (cited in note 12).

102 Id at 119, discussing Paul H. Robinson and Robert Kurzban, Concordance and Conflict in Intuitions of Justice, 91 Minn L Rev 1829, 1867-73, 1883-87 (2007). See also Peter H. Rossi and Richard A. Berk, A National Sample Survey: Public Opinion on Sentencing Federal Crimes *11-12 (US Sentencing Commission, 1995), archived at https://perma.cc/7PHH-MAN4.

103 Bibas, Machinery of Criminal Justice at 120 (cited in note 12).

104 Id.

105 See Tom R. Tyler, Why People Obey the Law 125-30, 135-40, 163-65 (Yale 1990). 
draw." 106 "[W]hile only a fraction of Americans live in small towns," Judge Bibas points out, "suburbs and cities comprise their own neighborhood communities" where residents repeatedly interact, creating "shared culture and experiences." 107 Any dissensus thus can be minimized by devolving decisions from the county or city down to the neighborhood level, which the democratizers urge for both prosecutors and the police. ${ }^{108}$

It is undeniable, after all, that cognizable minority communities dot the American landscape. Having created these enclaves, ${ }^{109}$ the least we can do is try to empower them. Indeed, one downside of our society's court-centered attachment to individual rights is "its disempowering effect on inner-city communities." 110 Inner-city residents are reasonable people who, if left alone, will figure things out through collective deliberation. ${ }^{111}$ Even where neighborhood residents disagree, that is, the deliberative process will generate wise decisions. ${ }^{112}$

Local communities, moreover, want a greater role. Reflective of American governance more generally, ${ }^{113}$ the people believe that insiders-lawyers, experts, and officials_-stole" the criminal law from them. "The public is hungry to see and understand criminal justice." 114 Crime victims are a prime example but they are not the only ones. "Wrongdoers, victims, and the public" all want "to

106 Bibas, Machinery of Criminal Justice at 162 (cited in note 12).

107 Id.

108 See id at 146; Kleinfeld, et al, 111 Nw U L Rev at 1702 (cited in note 29).

109 See generally Richard Rothstein, The Color of Law: A Forgotten History of How Our Government Segregated America (Liveright 2017).

110 Tracey L. Meares and Dan M. Kahan, When Rights Are Wrong: Chicago's Paradox of Unwanted Rights, Boston Rev 7 (Apr-May 1999) (emphasis omitted).

111 Tracey L. Meares and Dan M. Kahan, Meares and Kahan Respond, Boston Rev 22 (Apr-May 1999). See Kahan and Meares, When Rights Are Wrong at 7 (cited in note 110).

112 For arguments that deliberation improves decisions rather than merely aggregating individual preferences, see Jeffrey Abramson, We, the Jury: The Jury System and the Ideal of Democracy 205 (Basic Books 1994); James S. Fishkin, The Voice of the People: Public Opinion and Democracy 28 (Yale 1995); Archon Fung, Empowered Participation: Reinventing Urban Democracy 17 (Princeton 2004).

113 See, for example, Mathews, Politics for People at 11 (cited in note 63) (contending that the people have been "forced out of politics by a hostile takeover").

114 Bibas, Machinery of Criminal Justice at 35 (cited in note 12). Again, public desire to participate is understood to exist more broadly. See, for example, Thomas E. Cronin, Direct Democracy: The Politics of Initiative, Referendum, and Recall 5 (Harvard 1989) (claiming that people "would participate if they had a better way to make themselves heard"); Lawrence K. Grossman, The Electronic Republic: Reshaping Democracy in the Information Age 148 (Viking 1995) (referring to the "continu[ed] yearning of the American people to govern themselves"); Quentin Kidd, American Government: Readings from Across Society 5 (Longman 2000) (asserting that "[t]oday . . . the cry from people to be let in-to be able to share in the ruling of themselves-continues to be heard"). 
hear the defendant express remorse and apologize and the victim forgive." 115 They "hunger for a morality play" and "crave" their "day in court." 116 And even those who participate reluctantly-as many jurors concededly do-"report that participating increases their respect for the system and empowers them." 117

\section{Lay leniency.}

The democratizers maintain that laypeople hold relatively lenient attitudes toward criminal punishment. Enhancing lay control over sanctions, therefore, will temper the system's severity. ${ }^{118}$ The democratizers know this claim strikes many readers as counterintuitive. Some of our most draconian laws began as popular referenda. The label "soft on crime" is an albatross for politicians and judicial candidates of any stripe. ${ }^{119}$ If polled directly, the public will say that judges sentence too leniently. ${ }^{120}$ The democratizers concede all of this.

Yet context matters. "[O]rdinary citizens," cautions Judge Bibas, "have very poor information about how the criminal justice system actually works." 121 "Because voters are badly misinformed," he explains, "they clamor for tougher sentences, threestrikes laws, and mandatory minima across the board;" yet in reality, "voters are not as reflexively punitive as one might think." 122 "One cannot assume," in other words, "that current laws are harsh because that is what the public really wants; these laws

115 Bibas, Machinery of Criminal Justice at 72 (cited in note 12).

116 Id at 58, 72.

117 Id at 38 .

118 See, for example, Bowers, $111 \mathrm{Nw}$ U L Rev at 1664 (cited in note 32) (arguing that "[a] healthy dose of localism and populism may serve to moderate otherwise draconian enforcement decisions"); Kleinfeld, $111 \mathrm{Nw}$ U L Rev at 1407 (cited in note 14) ("Americans favor much less draconian levels of punishment than American law currently prescribes."); Robinson, $111 \mathrm{Nw}$ U L Rev at 1595 (cited in note 92) ("[S]hared judgments of justice are not brutish and draconian, but rather stand in stark contrast to the brutish and draconian measures created by ... general deterrence and incapacitation of the dangerous, which disconnect criminal law from the constraints of justice."); Simonson, $111 \mathrm{Nw}$ U L Rev at 1623 (cited in note 32) ("There is reason to think that if those most likely to be arrested and incarcerated were given truly equal influence over policy, and if policymaking happened more locally, then the criminal justice system would be less rather than more punitive.").

119 See, for example, Lord Windlesham, Politics, Punishment, and Populism 25 (Oxford 1998); Beale, 1 Buff Crim L Rev at 29 (cited in note 3).

120 Bibas, Machinery of Criminal Justice at 36 (cited in note 12). See also Lanni, Note, 108 Yale L J at 1780-81 (cited in note 92).

121 Bibas, Machinery of Criminal Justice at 36 (cited in note 12).

122 Id at 38. 
often result from a warped, dysfunctional political process." 123 "The average voter, if fully informed," Judge Bibas concludes, "would likely think the sentences on the books are tough enough in particular cases." 124

Worse yet, "[t]hough politicians frequently claim that their enactments are driven by public demand, it is often the case that they are in fact the motivation behind the public opinion itself." 125 The democratizers point here to sociologist Katherine Beckett's well-known work. ${ }^{126}$ The public's support for punitive legal reforms, Beckett finds, is generated largely by "political elites" who "shape[] ... public perceptions and sentiment" on criminal justice issues. ${ }^{127}$ Politicians provoke public concern by emphasizing crime in public speeches, statements, and policy proposals. ${ }^{128}$ Beckett presents regression analyses showing that (1) political and media attention to crime, rather than increasing crime rates, drives public concern about crime, and (2) public concern about crime responds to political attention to crime, rather than the other way around.129 The critical implication is that public support for punitive policies does not reflect a "universal and preexisting public desire" for harsh punishment. ${ }^{130}$

Apparently punitive attitudes also stem from ex ante consideration of crime and punishment- "wholesale" punishment choices rather than "retail" ones. ${ }^{131}$ Asked in the abstract about the appropriate punishment for an offense, for example, people "mentally fill in the blanks and base their sentencing recommendations on stereotypes or on memorable or recent examples" of that offense drawn from media accounts. ${ }^{132}$ "When people consider the actual details as jurors ex post," in contrast, "their perspectives change dramatically." 133 "When they are given concrete

123 Id at $\mathrm{xx}$

$124 \mathrm{Id}$ at 38

125 Paul H. Robinson, Geoffrey P. Goodwin, and Michael D. Reisig, The Disutility of Injustice, 85 NYU L Rev 1940, 1979 n 133 (2010).

126 See id at 1984-86, discussing Katherine Beckett, Making Crime Pay: Law and Order in Contemporary American Politics (Oxford 1997).

127 Beckett, Making Crime Pay at 107 (cited in note 126).

128 See id at 23.

129 See id at $21-25$

130 Id at 107.

131 See Bibas, Machinery of Criminal Justice at 38 (cited in note 12).

132 Id at 36

133 Id. Judge Bibas gives an example: "[E]ven though 88\% of survey respondents favored a mandatory three-strikes statute in the abstract, most favored one or more exceptions when presented with specific cases.” Id, citing Brandon K. Applegate, et al, Assessing 
cases," in fact, "average citizens favor sentences as low as or even markedly lower than those required by a variety of criminal laws." ${ }_{134}$ The democratizers cite empirical work by Professors Paul Robinson, Shari Diamond, and others. These studies find that, when presented with case vignettes, laypeople choose sentences below statutory minimums and in line with sentencing guidelines. ${ }^{135}$

\section{Bureaucratic severity.}

Hand in glove with the premise of lay leniency is a deep distrust of the governmental bureaucracy and the officials and experts who populate and participate in it. This "machinery of criminal justice," to borrow Judge Bibas's titular term, dispenses unfeeling, assembly-line justice without regard to person or circumstance. Efficiency reigns as "mass-produced [plea] bargains short-circuit elaborate constitutional procedures such as discovery, cross-examination, and jury instructions and deliberation."136 The role of lawyers is reduced to moving "the plea-bargaining machinery as quickly and cheaply as possible, which maximizes the number of people the system can deter and incapacitate." 137 And all this happens largely hidden from public view. ${ }^{138}$ In fact, reasons one recent account, "it may be [this] dedemocratization, the retrenchment of American democracy, that partially accounts for high rates of imprisonment in the United States." 139

Public Support for Three-Strikes-and-You're-Out Laws: Global Versus Specific Attitudes, 42 Crime \& Delinq 517, 522 tbl 2, 528-30 \& tbl 4 (1996).

134 Bibas, Machinery of Criminal Justice at xx-xxi.

135 Id at 36-37 (cited in note 12), citing Peter H. Rossi and Richard A. Berk, Just Punishments: Federal Guidelines and Public Views Compared 149 (Aldine de Gruyter 1997); Robinson, Goodwin, and Reisig, 85 NYU L Rev at 1949-78 (cited in note 125); Loretta J. Stalans and Shari Seidman Diamond, Formation and Change in Lay Evaluations of Criminal Sentencing: Misperception and Discontent, 14 L \& Hum Behav 199, 202 \& n 1, 205-07 \& tbls 2, 3 (1990).

136 Bibas, Machinery of Criminal Justice at xvi (cited in note 12).

137 Id.

138 See generally Jocelyn Simonson, The Criminal Court Audience in a Post-Trial World, 127 Harv L Rev 2173 (2014).

139 Vanessa Barker, The Politics of Imprisonment: How the Democratic Process Shapes the Way America Punishes Offenders 184 (Oxford 2009). See also Lisa L. Miller, The Perils of Federalism: Race, Poverty, and the Politics of Crime Control 181 (Oxford 2008) (arguing that "the problem is not that in the United States bureaucratic agencies of the criminal justice system are not sufficiently insulated from public pressure," but rather "that they are too insulated from the people who are most exposed to crime and violence on a regular basis"). 
Judges and other officials who work in this system grow numb. Judge Bibas, for instance, contrasts "jaded" professionals, including judges, with "less cynical" laypeople who serve on juries and advisory boards. ${ }^{140}$ He worries that judges may "los[e] a sense of perspective and grow[] to accept harsh drug sentences as the norm," for example. ${ }^{141}$ Consistent with this narrative, the democratizers cite studies in which laypeople presented with crime vignettes recommend lower sentences than judges or other officials do. In one frequently cited study, for example, lay jurors in Cook County selected sentences equal to or less severe than those selected by Illinois judges in a series of four vignettes. ${ }^{142}$

The "rationalism" and "centralization" that "have come to dominate criminal justice" through the bureaucracy also hamper mercy. ${ }^{143}$ To "Enlightenment minds and scientists," Judge Bibas claims, "mercy was arbitrary. Rational criminal justice, they thought, demanded equal, predictable deterrence, and mercy undercut deterrence." ${ }^{144}$ Put another way, "[t]he administrative ideal of equality across cases seemed to conflict with individualized justice and with compassionate mercy"; as a result, "both executive clemency and jury nullification dwindled." ${ }_{145}$ Parole, too, was standardized to increase sentencing predictability-necessary for effective plea bargaining-before it was later restricted or abolished. ${ }^{146}$ And sentencing guidelines sought to reduce disparity in part by cabining mercy, limiting the extent of and acceptable justifications for sentencing reductions. ${ }^{147}$

140 Bibas, Machinery of Criminal Justice at 32, 183 n 4 (cited in note 12), citing Harry Kalven Jr and Hans Zeisel, The American Jury 66-75, 115-16, 164-89 (Little, Brown 1966).

141 Bibas, Machinery of Criminal Justice at 32 (cited in note 12). Professor Jenia Iontcheva expresses a similar concern: "As judges themselves have admitted," she reports, "their daily exposure to sentencing and their political ambitions might sometimes harden their outlooks on punishment." Iontcheva, $89 \mathrm{Va}$ L Rev at 361 (cited in note 92).

142 See Shari Seidman Diamond and Loretta J. Stalans, The Myth of Judicial Leniency in Sentencing, 7 Behav Sci \& L 73, 74-75, 80 (1989), cited in Bibas, Machinery of Criminal Justice at 187 n 15 (cited in note 12); Lanni, Note, 108 Yale L J at 1796 n 97 (cited in note 92).

143 Bibas, Machinery of Criminal Justice at xxx (cited in note 12).

144 Id at 23.

145 Id at 24. See generally Rachel E. Barkow, The Ascent of the Administrative State and the Demise of Mercy, 121 Harv L Rev 1332 (2008).

146 Bibas, Machinery of Criminal Justice at 25 (cited in note 12). See also George Fisher, Plea Bargaining's Triumph: A History of Plea Bargaining in America 186-94 (Stanford 2003).

147 Bibas, Machinery of Criminal Justice at 25 (cited in note 12). 


\section{Equality.}

The democratizers' ideas of lay leniency and egalitarianism are tightly intertwined. "[M]oderation and equality," as Stuntz puts it, "travel together, reinforce one another." 148 This is partly a mechanical relationship: young black men have disproportionate contact with the justice system and thus bear the brunt of the system's severity. Any temperance, therefore, will disproportionately benefit this same population. There is, however, another aspect to the democratizers' antidiscrimination agenda, which registers not in disparate impact but discriminatory treatment. The democratizers argue that laypeople are basically egalitarian, at least toward members of their own racial or ethnic cohorts, and so shifting power to the local laity will reduce the effect of any discriminatory "outgroup" bias that elites and bureaucrats harbor. ${ }^{149}$

Stuntz gives the most compelling account.150 "In the late nineteenth and early twentieth centuries," Stuntz recounts, "when local politics governed the amount and distribution of criminal punishment, the justice system was stable, reasonably lenient, and surprisingly egalitarian." ${ }^{151}$ But "[i]n the twentieth century's second half," he continues, "[s]uburban populations mushroomed, diluting poor city neighborhoods' electoral power." ${ }^{152}$ During the 1950 s and $1960 \mathrm{~s}$, as violent crime rates rose in the increasingly black urban North, white suburban voters were indifferent, and imprisonment rates actually fell. ${ }^{153}$ "After the early 1970s," however, with crime still rising, "indifference gave way to anger." 154 Suburban voters- "for whom crime was at once frightening and distant"-demanded action, and county-elected prosecutors responded, prompting "the generation-long punitive turn that drove

148 William J. Stuntz, Unequal Justice, 121 Harv L Rev 1969, 2031 (2008).

149 See, for example, Stuntz, Collapse of American Criminal Justice at 312 (cited in note 15$)$ :

One reason black criminals from poor city neighborhoods have been treated with so much more severity than criminals from white immigrant communities in America's past is that the former are more easily categorized as The Other, as a people whose lives are separate from the lives of those who judge them.

150 For a consonant narrative, see Bibas, Machinery of Criminal Justice at 164 (cited in note 12 ).

151 Stuntz, 121 Harv L Rev at 1973 (cited in note 148).

152 Id.

153 See id.

154 Id at 2014. 
American prison populations into the stratosphere." ${ }^{155}$ Young black men shouldered most of the load.156

Stuntz's key insight was to see the problem as one of agency costs. For suburban voters - and for appellate judges "whose decisions shape policing and punishment on city streets"-_criminal justice policies are mostly political symbols or legal abstractions, not questions the answers to which define neighborhood life"; and "[d]ecisionmakers who neither reap the benefit of good decisions nor bear the cost of bad ones tend to make bad ones." 157 The way forward, then, is to "[p]lace more power in the hands of residents of those neighborhoods where the most criminals and crime victims live." 158 "Because residents of those neighborhoods suffer so much from crime, they are unlikely to support abandonment of the sort that Northern cities experienced in the 1950s, 1960s, and early 1970s," Stuntz assures; and "[b]ecause those same residents suffer so much from mass incarceration," he adds, "they are also unlikely to support the mindless severity" of the subsequent punitive turn. ${ }^{159}$ Unlike suburban voters and distant bureaucrats, black urban voters "are loath to incarcerate their sons and brothers, neighbors and friends." 160

\section{Compliance.}

Finally, the democratizers worry about flagging public esteem for criminal justice institutions, which, in turn, may weaken voluntary compliance with the law and cooperation and engagement with legal authorities. Their program aims to rehabilitate the justice system's image. The underlying premise is that repairing trust in the system will improve compliance with the law, which may then enable greater leniency. Two large literatures support this idea, both of which find that public willingness to defer to the law stems from a belief that the law is worthy of respect.

155 Stuntz, 121 Harv L Rev at 2010 (cited in note 148).

156 Id at 1971 (noting that black men are incarcerated at seven times the rate of their white counterparts).

157 Id at 1974.

158 Id at 2031-32.

159 Stuntz, 121 Harv L Rev at 2032 (cited in note 148).

160 Id at 1981. See also Miller, The Perils of Federalism at 156-57 (cited in note 139) (observing that "[o]ne major perspective that is conspicuous in its absence from citizen group advocacy at the local level is the punitiveness exhibited in state and national crime politics," where focus is not on "the people who have to live with both the realities of dayto-day threats of victimization as well as the contentious and often unproductive encounters with the justice system"). 
The first, associated most closely with Professor Tom Tyler, elaborates a theory of "procedural justice." 161 Procedural justice emphasizes the importance of fair procedures in shaping public perceptions that legal authorities are legitimate. Fairness, in this context, entails, among other things, impartiality, transparency, and-most relevant to the democratization agenda-voice: essentially, the chance to have one's views considered. ${ }^{162}$ This motivates the many civilian boards the democratizers propose to establish, as well as their specific recommendation that "[p]olice practices and a police culture consistent with norms of procedural justice, fairness, and legitimacy should be fostered."163 Juries, too, are thought to legitimate judicial verdicts, both for litigants and for broader society. ${ }^{164}$

It is not obvious, I should note, that procedural justice in its paradigmatic form - the police-civilian encounter-fits comfortably in the democratization agenda. The laity's involvement is neither necessary nor sufficient to implement a procedural justice approach to policing. That is to say, even an autocracy can instruct its agents to treat civilians in a procedurally just manner; meanwhile, procedural justice requires bureaucratic expertise for its execution. Still, a broader view of procedural justice encompasses not only this "retail" varietal-in the street meeting between officer and civilian-but also a "wholesale" one-in policylevel interactions between state institutions and the communities they serve. ${ }^{165}$ The latter is a more obvious exemplar of the democratization philosophy. Yet, to the extent that procedural fairness in retail interactions motivates cooperation with the authorities, it works to support the overall democratization agenda by fostering lay engagement. ${ }^{166}$

161 The canonical work, at least in criminal justice circles, is Tyler, Why People Obey the Law (cited in note 105).

162 See, for example, id at 163; Tom R. Tyler, Kenneth A. Rasinski, and Kathleen M. McGraw, The Influence of Perceived Injustice on the Endorsement of Political Leaders, 15 J Applied Soc Psych 700, 715-21 (1985).

163 Kleinfeld, et al, $111 \mathrm{Nw}$ U L Rev at 1699 (cited in note 29). See also Final Report of the President's Task Force at *1-2 (cited in note 11).

164 See Akhil Reed Amar, Sixth Amendment First Principles, 84 Georgetown L J 641, 681 (1996) ("[P]ublic participation in the criminal justice system was designed to enhance public legitimacy of the criminal justice system.").

165 See Meares, $111 \mathrm{Nw}$ U L Rev at 1531 (cited in note 32).

166 See id at 1532-35; Tom R. Tyler, From Harm Reduction to Community Engagement: Redefining the Goals of American Policing in the Twenty-First Century, $111 \mathrm{Nw}$ U L Rev 1537, 1552-54 (2017). 
The second compliance-related literature, associated with Paul Robinson and others, concerns "empirical desert." 167 Essentially, the criminal law's "moral credibility" increases the more the law comports-in what and how harshly it punishes-with lay views of desert. This notion is reflected in the democratizers' proposals for abolition of laws and practices "that violate community views of justice"; decriminalization "where the prohibited conduct is not wrong in itself given community views of justice"; grading of offenses that "reflect[s] community views of justice"; punishment based on blameworthiness as "determined by community standards of justice and actual social practice within the community in which the crime took place"; and sentencing juries. ${ }^{168}$

\section{Challenging the Premises}

This Part scrutinizes the democratizers' five central premises. A careful review of the evidence, I argue, shows that the democratizers have not made the case for the sweeping reforms they propose, some of which, in fact, may work against the movement's own stated purposes. Parts II.A-E take on the premises identified in Part I. Part II.F contends that, when the democratizers' proposals falter, the movement will splinter.

\section{A. Community}

The democratizers' first premise is that Americans reside in reasonably cohesive communities that are capable of forming and expressing-indeed, long to express_-community values" and "community views" of justice. This Section argues that (1) American neighborhoods have always been, and certainly are today, far more heterogeneous than the democratizers allow; (2) most laypeople do not wish to be more involved in governing the criminal justice system; and (3) a "community-based" system of criminal justice overlooks the extent to which neighborhoods are interconnected.

1. Heterogeneity.

Most accounts of democratization are nostalgic, even romantic. They gaze backwards, to eras before today's carceral state, to understand why criminal justice used to work and where it went

167 See Robinson, Goodwin, and Reisig, 85 NYU L Rev at 1943 (cited in note 125).

168 Kleinfeld, et al, $111 \mathrm{Nw}$ U L Rev at 1697-1703 (cited in note 29). 
astray. Judge Bibas, for example, praises the "village ideal" of colonial America and its criminal justice "morality plays." 169 For Stuntz, the Gilded Age was golden. ${ }^{170}$ Community policing advocates envision folksy, small-town Mayberry. ${ }^{171}$ In these earlier days, all agree, Americans clustered in tight-knit, self-governing communities. ${ }^{172}$ Criminal justice was naturally lenient and egalitarian because the same people who doled out punishment bore its costs. Its substance, moreover, reflected the shared values of those homogeneous groups. ${ }^{173}$

If this sounds too sanguine, it is. "We the people" have always been an exclusive bunch. ${ }^{174}$ We can imagine idyllic, homogeneous colonial villages only by blinking the women, blacks, and other marginalized groups who did not share in old-world selfgovernance. For these groups, the criminal justice system was not a site of democratic participation but rather an instrument for maintaining an oppressive social hierarchy and expelling nonconformists. ${ }^{175}$ Neighbors were not only friends but also spies-the prying eyes of the church on "brotherly watch." 176 Punishment in

169 Bibas, Machinery of Criminal Justice at 116-17 (cited in note 12).

170 Stuntz, Collapse of American Criminal Justice at 129-57 (cited in note 15). At one point, Stuntz describes the Gilded Age as "the half-century between Reconstruction's end and the Great Depression's beginning." Id at 8. Stuntz's Gilded Age therefore includes what others might call the Progressive Era and Roaring Twenties. It's also possible to read Stuntz's period of interest as running all the way through the 1950s. See Stephen J. Schulhofer, Book Review, Criminal Justice, Local Democracy, and Constitutional Rights, 111 Mich L Rev 1045, 1047 (2013).

171 Mayberry was the fictional setting for The Andy Griffith Show, which gave 1960s Americans "a glimpse (albeit mythical) of the ways in which policing was thought to be accomplished in much of rural and small-town America." John Liederbach and James Frank, Policing Mayberry: The Work Routines of Small-Town and Rural Officers, 28 Am J Crim Just 53, 53 (2003).

172 See Bibas, Machinery of Criminal Justice at 2 (cited in note 12) (describing "closeknit" and "fairly homogeneous" early American communities in which "people knew and agreed on what acts were right and wrong," especially in religious colonies); Samuel Walker, Popular Justice: A History of American Criminal Justice 15 (Oxford 2d ed 1998) ("New England villages were almost entirely white, English, and Protestant. . . . Southern colonies were different only in terms of the presence of the slave population.").

173 See Walker, Popular Justice at 15 (cited in note 172) ("In [the colonial village] context, there was a high degree of consensus over proper behavior.”).

174 See, for example, Lawrence M. Friedman, Crime and Punishment in American History 12 (Basic Books 1993) ("Nobody could honestly call the colonial systems 'democratic.' They were little theocracies."). See generally Aziz Rana, The Two Faces of American Freedom (Harvard 2010) (describing the entanglement of American principles of internal self-governance and the subordination of marginalized groups such as slaves, Native Americans, and women).

175 See Walker, Popular Justice at 20, 23 (cited in note 172).

176 Id at 18-19. Real colonial justice, explains Professor Nicola Lacey, tolerated "a pervasive executive and judicial discretion that led in general to wildly unequal justice 
these tight-knit communities could be brutal and deeply stigmatizing: the stocks, flogging, and widely attended hangings were common. ${ }^{177}$ These were the days when " $[\mathrm{m}] \mathrm{en}$ feared witches and burnt women." 178 Shared fates did not temper justice.

Stuntz's Gilded Age was hardly more inclusive. Women still couldn't vote in most states. Race riots racked the nation in 1919. ${ }^{179}$ Peonage and Jim Crow ruled the South; lynch mobs had little fear of sanction. ${ }^{180}$ Blacks fared only slightly better in the North. Indeed, it was white social scientists, journalists, and public figures in the urban North who, around the nineteenth century's end, formulated modern ideas about black criminality. ${ }^{181}$ In response, black researchers exposed the pervasive role of white racism in turn-of-the-century northern criminal justice. ${ }^{182}$ Even in largely white locales, ethnic conflicts corrupted police administration. ${ }^{183}$

The democratizers do see these concerns. None of them wants to revisit the colonies' brutal punishments or resurrect Jim Crow. "There is much in our history to deplore," Judge Bibas concedes. ${ }^{184}$

and in particular to the disproportionate, and sometimes bloodthirsty, criminalization of those regarded as being of bad character or as being otherwise marginal or dangerous." Nicola Lacey, Book Review, Humanizing the Criminal Justice Machine: Re-Animated Justice or Frankenstein's Monster?, 126 Harv L Rev 1299, 1312 (2013).

177 Walker, Popular Justice at 14 (cited in note 172). See id at 16 (describing the authorization of death sentences for a child's cursing or striking a parent); id at 32-35 (describing public whipping, branding, and mutilation of offenders).

178 Whitney v California, 274 US 357, 376 (1927) (Brandeis concurring). See also Michael Stephen Hindus, Prison and Plantation: Crime, Justice, and Authority in Massachusetts and South Carolina, 1767-1878 49 (UNC 1980) (describing the prosecution of pregnant brides for fornication in Massachusetts).

179 See Walker, Popular Justice at 148-49 (cited in note 172). See also Friedman, Crime and Punishment in American History at 13 (cited in note 174).

180 See Walker, Popular Justice at 76 (cited in note 172); David Garland, Penal Excess and Surplus Meaning: Public Torture Lynchings in Twentieth-Century America, 39 L \& Socy Rev 793, 795 (2005) (arguing that "lynchings were, first and foremost, collective criminal punishments").

181 See Khalil Gibran Muhammad, The Condemnation of Blackness: Race, Crime, and the Making of Modern Urban America 3-9 (Harvard 2010).

182 See id at $10-12$.

183 Walker, Popular Justice at 56 (cited in note 172). "[T] his was not a period when ethnic communities were policed by "their own"; "people often mistrusted cops on the beat because the officers were unfamiliar with the language and customs of recent immigrant communities.” Schulhofer, Book Review, 111 Mich L Rev at 1055 (cited in note 170).

184 Bibas, Machinery of Criminal Justice at 13 (cited in note 12). 
They urge us instead to focus on how old-fashioned criminal justice worked "within the circle of moral equality." 185 Borrow the good parts, the theory goes, and leave behind the bad. And the "circle of moral equality" is larger now, so we can import older models of criminal justice without adopting their pathologies as well. ${ }^{186}$

But can we? Suppose I am overly cynical about old-world "community." Suppose, that is, that genuine "community" did exist in the colonies or the Gilded Age, at least within the "circle of moral equality." Times have changed. Criminologist Samuel Walker puts it well: "The informality and [ ] apparent effectiveness of the colonial approach to crime and justice were rooted in a world that is long gone and cannot be recreated." 187 Contemporary America is incredibly diverse. As early as 1922, a prominent study recognized that Cleveland had become "a city of strangers" 188 and that informality and local control were "out of place in the city of today." 189 Policing's "old basis in personal relationships and local rapport had disappeared forever," writes Professor Stephen Schulhofer, and "the beguiling vision of cohesive communities had passed out of reach."190

To be sure, the democratizers concede this as well. ${ }^{191}$ Yet they don't seem to acknowledge its implications. In rejecting the democratizers' appeals to nostalgia, the point is not simply to insist, dogmatically, that they must take the bad with the good. The point is that their historical examples fail to show "community justice" actually succeeding in a complex, heterogeneous society

185 Kleinfeld, $111 \mathrm{Nw}$ U L Rev at 1369 (cited in note 14). See also Stuntz, Collapse of American Criminal Justice at 68 (cited in note 15) ("For most of the nation's history, those ... institutions functioned reasonably well (outside the South—an important qualification).").

186 See also Tracey L. Meares and Dan M. Kahan, The Wages of Antiquated Procedural Thinking: A Critique of Chicago v. Morales, 1998 U Chi Legal F 197, 207-08 (arguing that, now that blacks are "no longer excluded from the nation's democratic political life," courts should defer to local democratic choices about policing policies).

187 Walker, Popular Justice at 3 (cited in note 172).

188 Raymond B. Fosdick, Police Administration, in Roscoe Pound and Felix Frankfurter, eds, Criminal Justice in Cleveland: Reports of the Cleveland Foundation Survey of the Administration of Criminal Justice in Cleveland, Ohio 6-7 (Cleveland Foundation 1922) (Cleveland Report).

189 Roscoe Pound, Criminal Justice and the American City-A Summary, in Pound and Frankfurter, eds, Cleveland Report 557, 615 (cited in note 188).

190 Schulhofer, Book Review, 111 Mich L Rev at 1052 (cited in note 170). See also Nicole P. Marwell, Bargaining for Brooklyn: Community Organizations in the Entrepreneurial City 14 (Chicago 2007); Paul E. Peterson, City Limits 116 (Chicago 1981); Albert J. Reiss Jr, The Police and the Public 209 (Yale 1971).

191 See Bibas, Machinery of Criminal Justice at 14 (cited in note 12). 
like today's. 192 Whatever success old-world justice can claim, that success occurred under circumstances we long ago left behind. To put the point differently, even on the democratizers' sunnier historical account, the criminal justice system of colonial America, to pick an example, simply did something different from what we need our law to do today. Colonial justice enforced the dominant norms of white Christian men and excluded those who would not conform. It did not attempt to reconcile conflicting views of a heterogeneous populace. ${ }^{193}$

True, the democratizers might respond, America today is more diverse than ever before. Yet heterogeneous peoples do not necessarily hold heterogeneous views on criminal justice. Quite to the contrary, work by Professor Paul Robinson and others work has found surprising concordance in lay judgments of desert. Researchers in these studies ask participants to order a set of crime descriptions by severity. They find "a high degree of agreement about judgments of justice across all demographics, at least for what one might call the core of wrongdoing." 194 Community views of justice, in other words, may cohere even as communities themselves grow increasingly diverse.

This research is undoubtedly important. I am skeptical, however, that it can carry the weight of the democratizers' case on this point. Two basic problems stand out. First, there is a credible argument that Robinson-and those who rely on his findingsoverstate the extent of lay consensus. Robinson's concordance studies exclude "victimless" (or "vice") crimes, which are "crimes over which there is tremendous public disagreement" and which

192 See Schulhofer, Book Review, 111 Mich L Rev at 1073 (cited in note 170) (“[A] city's ability, before 1960, to control crime through informal institutions without harsh punishment tells us very little about the capacity of such institutions to succeed under the conditions that took hold so quickly thereafter."). For evidence that growing diversity has contributed to the decline of town hall deliberative democracy, see Jane J. Mansbridge, Beyond Adversary Democracy 68 (Chicago 2d ed 1983).

193 See Walker, Popular Justice at 15 (cited in note 172) (describing colonial justice as "aggressively conformist"); id at 19 ("When there were serious disagreements, especially over . . . theology, the consensus broke down, and the dissenting minority often packed up and moved away to establish a separate community.").

194 Robinson, 111 Nw U L Rev at 1567 (cited in note 92). See, for example, Paul H. Robinson, Intuitions of Justice and the Utility of Desert 18-34 (Oxford 2013). See also Rossi and Berk, A National Sample Survey at *9-12 (cited in note 102). For cross-national or cross-cultural applications, see generally Sandra S. Evans and Joseph E. Scott, The Seriousness of Crime Cross-Culturally: The Impact of Religiosity, 22 Crimin 39 (1984); Sergio Herzog, Public Perceptions of Crime Seriousness: A Comparison of Social Divisions in Israel, 39 Isr L Rev 57 (2006). 
form the majority of all offenses committed. ${ }^{195}$ In addition, the core-periphery distinction on which Robinson relies is unstable across cultural groups. Kuwaitis, to give one example, view adultery as being far more serious than Americans do. ${ }^{196}$ Moreover, even within the core, people often disagree about when offenses have occurred. Everyone opposes murder, rape, and misappropriation, that is-Robinson's core-but they disagree about "what counts as murder, rape, and misappropriation."197

Second, the consensus Robinson does find concerns only relative, not absolute, blameworthiness. People largely agree, that is, on how to rank offenses in order of severity. But Robinson does not find that people agree on how severely to punish any particular offense, and many others have found that they do not. ${ }^{198}$ For a project that envisions aligning criminal punishment with "community views of justice," or expressing "community views" through sentencing juries, this distinction matters. Robinson argues that, once an "endpoint" for maximal punishment is chosen, everything will fall into place according to the consensus ordinal ranking. ${ }^{199}$ Yet the choice of endpoint is crucial and itself contentious. If people disagree about the endpoint, therefore-and they do-they are apt to disagree about the entire sentencing hierarchy that descends from that extreme.200

195 Donald Braman, Dan M. Kahan, and David A. Hoffman, Some Realism About Punishment Naturalism, 77 U Chi L Rev 1531, 1552 (2010). See id at 1552-56. Elsewhere, Robinson himself refers to "core" offenses as "a select few." Paul H. Robinson, Owen D. Jones, and Robert Kurzban, Realism, Punishment, and Reform, 77 U Chi L Rev 1611, 1612 (2010).

196 See Braman, Kahan, and Hoffman, 77 U Chi L Rev at 1557-58 (cited in note 195).

197 Id at 1604 (emphasis omitted).

198 See, for example, Rossi and Berk, A National Sample Survey at *12 (cited in note 102); Peter H. Rossi, Jon E. Simpson, and JoAnn L. Miller, Beyond Crime Seriousness: Fitting the Punishment to the Crime, 1 J Quant Crimin 59, 72-81 (1985); Christopher Slobogin and Lauren Brinkley-Rubinstein, Putting Desert in Its Place, 65 Stan L Rev 77, 94-96 (2013). But see William Samuel and Elizabeth Moulds, The Effect of Crime Severity on Perceptions of Fair Punishment: A California Case Study, 77 J Crim L \& Crimin 931, 945-48 (1986) (finding widespread agreement among California residents on sentencing preferences).

199 See Paul H. Robinson and John M. Darley, Intuitions of Justice: Implications for Criminal Law and Justice Policy, 81 S Cal L Rev 1, 33-35 (2007).

200 See Rossi and Berk, A National Sample Survey at *9 (cited in note 102) ("[I]t is important to note that severity studies are not about sentencing. To derive desired sentences from rated severity it is necessary to know how the two are related, a critical issue on which the severity studies are largely silent."); Joseph E. Jacoby and Francis T. Cullen, The Structure of Punishment Norms: Applying the Rossi-Berk Model, 89 J Crim L \& Crimin 245, 305-07 (1998) (arguing that, because of this disagreement, public opinion cannot be used as a basis for sentencing guidelines); Joseph E. Kennedy, Empirical Desert and the Endpoints of Punishment, in Paul H. Robinson, Stephen P. Garvey, and Kimberly Kessler Ferzan, eds, Criminal Law Conversations 54, 54 (Oxford 2009) (asserting that 
Perhaps because of concern on this very point-that is, the problems of heterogeneity and disagreement-the democratizers tend to focus on the microlocal. ${ }^{201}$ Theirs is a theory of neighborhoods, not cities. And while contemporary society is more heterogeneous than ever before-and may not share uniform views on punishment-residential segregation ensures that neighborhoods retain a more singular flavor. ${ }^{202}$ Indeed, the democratization literature brims with rhetoric about empowering "black" and "minority communities." 203 Residents of these neighborhoods, the democratizers presume, share values that broader society may not.

Two problems plague this argument as well. First, while residential segregation surely remains high compared to what many of us would consider ideal, it's lower than people think, and it's falling quickly. ${ }^{204}$ Most black Americans, for example, do not live in "black communities," nor do they live in big cities. ${ }^{205}$ On top of

Robinson's finding of universality in judgments of empirical desert has "limited utility" because "[m]aximum punishments differ greatly between societies"); Peter H. Rossi and J. Patrick Henry, Seriousness: A Measure for All Purposes?, in Malcolm W. Klein and Katherine S. Teilmann, eds, Handbook of Criminal Justice Evaluation 489, 491 (Sage 1980) ("[A]greement on the relative ordering of criminal acts is compatible with considerable differences in the absolute level of seriousness attributed to any given act.").

201 See, for example, Kleinfeld, 129 Harv L Rev at 1562 (cited in note 67) ("[F]ederalism and other forms of localism . . . can be used to reduce the incidences of value disagreement and the need to work out universal values."). But see Josh Bowers and Paul H. Robinson, Perceptions of Fairness and Justice: The Shared Aims and Occasional Conflicts of Legitimacy and Moral Credibility, 47 Wake Forest L Rev 211, 233 (2012) ("In the . . context of empirical desert, we think it makes sense to define the relevant community as the populace covered by a contemplated liability or punishment rule, because the reach of substantive criminal law typically extends all the way to the state's borders.").

202 See, for example, Appleman, Defending the Jury at 78 (cited in note 86) ("Individual communities in the United States have tended to remain ... segregated according to race, ethnicity, and class - therefore rendering localized communities more homogeneous.").

203 See, for example, Simonson, $111 \mathrm{Nw}$ U L Rev at 1615 n 25 (cited in note 32) ("A democracy-enhancing theory of criminal law ... prioritiz[es] the empowerment of lowincome and minority individuals and communities to participate more fully in the formation and implementation of criminal justice policies."), quoting Janet Moore, Democracy Enhancement in Criminal Law and Procedure, 2014 Utah L Rev 543, 566; Kleinfeld, 111 $\mathrm{Nw}$ U L Rev at 1409 (cited in note 14) (arguing that the "poor, black neighborhoods most affected by crime are also the neighborhoods most affected by excessive punishment and policing," and therefore ought to take the lead in calibrating criminal justice policy).

204 For a good review of the evidence, see Nicholas O. Stephanopoulos, Civil Rights in a Desegregating America, 83 U Chi L Rev 1329, 1343-48 (2016).

205 Paul Jargowsky, Are Minority Neighborhoods a Disaster? (The Century Foundation, Oct 14, 2016), online at https://tcf.org/content/commentary/minority-neighborhoods -disaster (visited Feb 19, 2020) (Perma archive unavailable) (reporting that 42 percent of black Americans live in neighborhoods that are majority black); Alana Semuels, No, Most Black People Don't Live in Poverty —or Inner Cities (The Atlantic, Oct 12, 2016), archived at https://perma.cc/X3FY-RWKV (reporting that 52 percent of black Americans in the top one hundred metropolitan areas live in suburbs). 
that, residential mobility is high, especially in urban areas. ${ }^{206}$ If shared values come from shared experiences, then mobility weakens those values. ${ }^{207}$ For these reasons and more, a large literature critiques the assumption of unitary, easily defined "communities" the democratizers imagine will self-govern in their members' interests. ${ }^{208}$ The democratizers are not oblivious to this critique but they provide no satisfactory response.

Second, even "black neighborhoods," where they do persist, are far from monolithic. ${ }^{209}$ "Property owners, tenants, shopkeepers, senior citizens, teenagers, and the homeless," Schulhofer points out, "have divergent interests. Who speaks for this 'community?"210 Many older blacks, for example, are concerned about

206 See generally Claudia Coulton, Brett Theodos, and Margery A. Turner, Residential Mobility and Neighborhood Change: Real Neighborhoods Under the Microscope, 14 Cityscape: J Pol Dev \& Rsrch 55 (2012).

207 See Mark E. Correia, Citizen Involvement: How Community Factors Affect Progressive Policing 7 (Police Executive Research Forum 2000) (discussing arguments that "attempts to instill (or build) a sense of community have become exceedingly difficult in a society that is highly mobile and individualistic"); Reiss, The Police and the Public at 209 (cited in note 190). Residential mobility creates "temporal spillover effects" as well: "What does local autonomy mean," Professor Rich Schragger asks, "in a mobile society where changes in the make-up of local populations occur over the span of years as opposed to decades or longer?" Richard C. Schragger, The Limits of Localism, 100 Mich L Rev 371, 424 (2001).

208 See, for example, Steve Herbert, Citizens, Cops, and Power: Recognizing the Limits of Community 12 (Chicago 2006) ("[M] any people do not understand community as spatially bounded; urban residents often seek community outside their neighborhood."); Michael E. Buerger, A Tale of Two Targets: Limitations of Community Anticrime Actions, in David R. Karp, ed, Community Justice: An Emerging Field 137, 148-50 (Rowman \& Littlefield 1998) (arguing that community policing often uses "community" rhetoric to refer to "the people living in a given bounded district," who may not actually share common concerns); Carl B. Klockars, The Rhetoric of Community Policing, in Jack R. Greene and Stephen D. Mastrofski, eds, Community Policing: Rhetoric or Reality 239, 247-50 (Praeger 1988) ("Nothing, in fact, is more different from community than those relationships that characterize most of modern urban life.").

209 See, for example, Michael C. Dawson, Black Visions: The Roots of Contemporary African-American Political Ideologies 2 (Chicago 2001); Mary Pattillo, Black on the Block: The Politics of Race and Class in the City 2 (Chicago 2007); Regina Austin, "The Black Community," Its Lawbreakers, and a Politics of Identification, 65 S Cal L Rev 1769 (1992); Justin Driver, Rethinking the Interest-Convergence Thesis, 105 Nw U L Rev 149, 166-71 (2011); Robert Weisberg, Restorative Justice and the Danger of "Community", 2003 Utah L Rev 343, 348. For the more general point, see Schulhofer, Book Review, 111 Mich L Rev at 1082 (cited in note 170) (arguing that, even if we could isolate ethnically and socioeconomically homogeneous enclaves, "we cannot plausibly assume that the people within those boundaries constitute a single 'community' with coherent, unified preferences").

210 Schulhofer, Book Review, 111 Mich L Rev at 1082 (cited in note 170). See also Correia, Citizen Involvement at 7 (cited in note 207) ("A vexing concern for [communityoriented policing] programs has been the inability to establish a sense of community in disadvantaged neighborhoods."). 
the younger generation. ${ }^{211}$ Class cleavages divide black neighbors. ${ }^{212}$ In fact, in a 2007 Pew poll, nearly four in ten black respondents said that, given intrablack diversity, blacks can no longer be thought of as a single race. ${ }^{213}$ Yet "[b]ecause whites by and large don't see black Americans as a complex population of differentiated individuals," writes political scientist Adolph Reed in an acerbic critique, "the organic community imagery seems reasonable and natural to them." 214

Consider the intense debate over whether the "black community" supported the loitering ordinance invalidated in City of Chicago v Morales. ${ }^{215}$ Professors Dan Kahan and Tracey Meares argued that Chicago's law deserved special deference because it "was to be enforced only after consultation with 'local leaders' and 'community organizations'-the representatives of the average citizen." 216 Others saw it quite differently. Professors Albert Alschuler and Stephen Schulhofer observed that white aldermen had drafted the ordinance, which was backed by Mayor Daley's administration; that the Chicago chapter of the NAACP and the editorial page of the city's leading black newspaper denounced the proposal; and that more black alderman voted against the ordinance than for it. ${ }^{217}$ Reviewing the legislative history, Professor Dorothy Roberts similarly finds diverse black opinions on the matter. ${ }^{218}$

The democratizers acknowledge this too, in their more careful moments. They might even say I caricature their position in suggesting it assumes total consensus at the local neighborhood level. But if the democratizers allow for dissent and disagreement within communities, then they need some mechanism for resolv-

211 See Cathy J. Cohen, Democracy Remixed: Black Youth and the Future of American Politics 24 (Oxford 2010).

212 See, for example, Michael C. Dawson, Not in Our Lifetimes: The Future of Black Politics 94-97 (Chicago 2011) (describing an election to fill Barack Obama's former state assembly seat as "about the intersection of race and class in a Chicago neighborhood").

213 Blacks See Growing Values Gap Between Poor and Middle Class (Pew Research Center, Nov 13, 2007), archived at https://perma.cc/YQL6-TRNY.

214 Adolph Reed Jr, Class Notes: Posing as Politics and Other Thoughts on the American Scene 11 (New Press 2000).

215527 US 41 (1999).

216 Dan M. Kahan and Tracey L. Meares, Foreword: The Coming Crisis of Criminal Procedure, 86 Georgetown L J 1153, 1183 (1998) (citation omitted).

217 See Albert W. Alschuler and Stephen J. Schulhofer, Antiquated Procedures or Bedrock Rights? A Response to Professors Meares and Kahan, 1998 U Chi Legal F 215, 217-20.

218 Dorothy E. Roberts, Foreword: Race, Vagueness, and the Social Meaning of OrderMaintenance Policing, 89 J Crim L \& Crimin 775, 822-26 (1999). 
ing that disagreement in the course of generating unified "community views" on policing, punishment, and so on. They seldom specify how this is going to work. Take Kahan and Meares, for example, who urged judicial deference to the judgments of inner-city communities on policing strategies. As Sklansky observes, Kahan and Meares's analysis "give[s] little attention to the structures through which these communities actually make decisions."

The most obvious possibility is voting. When community members disagree on police or prosecutorial priorities, they should take a vote. But once we get to this point, what is left of participatory democracy? It begins to feel more like a parlor trick: take a group of people who disagree, have them vote, and then call the result the "will of the community" when it's really just majoritarianism. "Community" becomes the product of, rather than a justificatory premise of, the democratization agenda. Kleinfeld emphasizes that voting in these settings should occur only after group deliberation. ${ }^{220}$ But this distinction may be more sentimental than real-research from the jury-deliberation setting suggests that deliberation only rarely changes minds. ${ }^{221}$

I suspect many democratizers would not resort to voting so soon. Consensus, they would say, is how communities resolve disagreement. Community meetings, town halls, beat meetingsthese (not the ballot) are the stuff of which democratization is made. Here, however, the democratizers confront another difficulty. The theory on which they ground their vision-deliberation theory-is entirely idealized. It envisions what philosopher Jürgen Habermas calls an "ideal speech situation," 222 with exchange among "free and equal citizens . . . motivated by justice or the common good." ${ }^{223}$ Deliberation theory predicts consensus,

219 Sklansky, Democracy and the Police at 100 (cited in note 13). See also Reed, Class Notes at 10 (cited in note 214) (critiquing the view that "we don't need to ask how the community makes its decisions, how it forms its will, because it reflects an immediate, almost mystical identity of interest and common feeling").

220 See Kleinfeld, $111 \mathrm{Nw}$ U L Rev at 1470 n 44 (cited in note 61).

221 See, for example, Valerie P. Hans and Neil Vidmar, Judging the Jury 112, 119 (Plenum 1986); Kalven and Zeisel, The American Jury at 488 (cited in note 140). See also Dennis J. Devine, Jury Decision Making: The State of the Science 158-61 (NYU 2012) (collecting additional studies). But see Shari Seidman Diamond and Mary R. Rose, The Contemporary American Jury, 14 Ann Rev L \& Soc Sci 239, 250-53 (2018) (arguing that deliberations matter to outcomes and citing studies).

222 Jürgen Habermas, 1 The Theory of Communicative Action: Reason and the Rationalization of Society 25 (Beacon 1984) (Thomas McCarthy, trans).

223 Samuel Freeman, Deliberative Democracy: A Sympathetic Comment, 29 Phil \& Pub Affairs 371, 380 (2000). See also Habermas, 1 The Theory of Communicative Action at 25 (cited in note 222). 
moreover, only if these free and equal citizens deliberate rationally, eschewing irrelevant information, bad logic, and unverifiable assertions. ${ }^{224}$

As deliberation theorists recognize, real deliberation is defective on these measures. ${ }^{225}$ From here, they typically go in one of two directions. First, some theorists endeavor to identify the hypothetical consensus that would have emerged if the preconditions for deliberation had been met. ${ }^{226}$ Kleinfeld rejects this as a viable path for the democratization project, which is understandable given the democratizers' commitment to popular rule. ${ }^{227}$ Second, other theorists-and the democratizers, it seems-simply forge ahead despite the imperfections of real-world deliberation. ${ }^{228}$ This choice is also understandable but "diverts attention," as Sklansky points out, "from the ongoing power dynamics" of deliberating groups. ${ }^{229}$ "[O]ne person's consensus," after all, "is often another's hegemony." 230

Indeed, a mountain of research-much of it from the community policing literature-finds that, in practice, deliberative mechanisms tend to amplify predictably dominant voices while muffling others. In other words, the "community values" that appear to emerge from community meetings and the like disproportionately reflect relatively powerful factions of the community. ${ }^{231}$

224 See, for example, Simone Chambers, Reasonable Democracy: Jürgen Habermas and the Politics of Discourse 98-99 (Cornell 1996); Amy Gutmann and Dennis Thompson, Democracy and Disagreement 52-94 (Belknap 1996); Jürgen Habermas, 2 The Theory of Communicative Action: Lifeworld and System: A Critique of Functionalist Reason 49 (Beacon 1987) (Thomas McCarthy, trans).

225 See, for example, Gutmann and Thompson, Democracy and Disagreement at 3 (cited in note 224).

226 See Habermas, Between Facts and Norms at 107-08 (cited in note 59).

227 See Kleinfeld, $111 \mathrm{Nw}$ U L Rev at 1470 (cited in note 61).

228 See id at 1470-71. See also Gutmann and Thompson, Democracy and Disagreement at 16, 358-59 (cited in note 224); Christopher H. Schroeder, Deliberative Democracy's Attempt to Turn Politics into Law, 65 L \& Contemp Probs 95, 111-13, 116-17 (2002). For commentary on this choice, see Jon Elster, The Market and the Forum: Three Varieties of Political Theory, in James Bohman and William Rehg, eds, Deliberative Democracy: Essays on Reason and Politics 3, 18 (MIT 1997); Frederick Schauer, Talking as a Decision Procedure, in Stephen Macedo, ed, Deliberative Politics: Essays on Democracy and Disagreement 17, 20-26 (Oxford 1999).

229 Sklansky, Democracy and the Police at 104 (cited in note 13).

230 Ian Shapiro, Three Ways to Be a Democrat, 22 Pol Theory 124, 134 (1994).

231 See, for example, Herman Goldstein, Policing a Free Society 146 (Ballinger 1977); Mansbridge, Beyond Adversary Democracy at 276 (cited in note 192); Wesley G. Skogan, Representing the Community in Community Policing, in Wesley G. Skogan, ed, Community Policing: Can It Work? 57, 71-73 (Wadsworth 2004). Some of the democratizers acknowledge this concern. See, for example, Jocelyn Simonson, The Place of 'the People' in Criminal Procedure, 119 Colum L Rev 249, 286 (2019). 
Preeminent policing scholar Herman Goldstein observed firsthand that, "absent vigorous representation of the people affected, persons attracted to membership on such a body are inclined to encourage and support some of the very police practices to which the advocates of decentralized decision-making are most strongly opposed." ${ }^{232}$ In short, participatory democracy will always favor those who have the time and wherewithal to participate, and the human capital to dominate. ${ }^{233}$

The broader point is that it is too facile to assume that "whereas less-than-ideal speech situations will generate fewer benefits than ideal speech situations, any verbal interaction, however imperfect, is better than nothing." ${ }^{334}$ In fact, "deliberation in the real world can be and often is dangerous": it can "fan emotions unproductively, can exacerbate rather than diminish power differentials among those deliberating, ... is ill-suited to many issues, and can lead to worse decisions than would have occurred if no deliberation had taken place.”235

\section{Apathy and alienation.}

Suppose we assume away all of these problems. We imagine that Americans reside in local communities of interest that share, to a large extent, a set of values relevant to criminal justice policy. And where individuals disagree, an acceptable method exists for

232 Goldstein, Policing a Free Society at 146 (cited in note 231). As Goldstein's observation reveals, disempowered voices can be silenced not only because they speak more quietly but also through exclusion from the conversation altogether. See, for example, Wesley G. Skogan, et al, Community Policing in Chicago, Year Ten: An Evaluation of Chicago's Alternative Policing Strategy iii (Illinois Criminal Justice Information Authority 2004); James Forman Jr, Community Policing and Youth as Assets, 95 J Crim L \& Crimin 1, 16-20 (2004). For discussion of how self-selection into voluntary community groups creates a "communitarian fallacy of homogeneity," see Mark Peel, Trusting Disadvantaged Citizens, in Valerie Braithwaite and Margaret Levi, eds, Trust and Governance 315, 339 (Russell Sage Foundation 1998).

233 It is unnecessary to infer any nefarious motives here. Political theorist Arnold Kaufman observes that a small number of individuals may "choose, at great personal sacrifice and out of a genuine sense of civic responsibility, to attend all the meetings. They give up so much that they quite understandably come to think that they are the vanguard of good citizenry of the future." Arnold S. Kaufman, Participatory Democracy: Ten Years Later, in William E. Connolly, ed, The Bias of Pluralism 201, 209 (Atherton 1969).

234 John R. Hibbing and Elizabeth Theiss-Morse, Stealth Democracy: Americans' Beliefs About How Government Should Work 190 (Cambridge 2002).

235 Id at 190-91. See also id at 246-54; Achen and Bartels, Democracy for Realists at 299-303 (cited in note 31); Jason Brennan, Against Democracy 58-73 (Princeton 2016). 
extracting "the community's view." Still, a major question remains: What evidence is there that these communities actually want to participate in the administration of criminal justice?

a) "Stealth democracy." The democratizers describe an eager public clamoring at the gates of power, blocked from entry by insiders who have stolen their disputes to feed the machinery of bureaucratic justice. These are de Tocqueville's Americans, who "feel an immense void" when excluded from consideration of "the interests of the community." 236 Evocative as it is, this account is largely fictional-a story told by the elite. For most ordinary people, the truth is that "participatory democracy simply takes too many evenings." 237

Political scientists John Hibbing and Elizabeth Theiss-Morse set out to examine the conventional wisdom that people want to govern themselves by surveying ordinary people and convening focus groups around the country. ${ }^{238}$ They found, perhaps surprisingly, that " $[t]$ he last thing people want is to be more involved in political decision making: They do not want to make political decisions themselves[] [and] they do not want to provide much input to those who are assigned to make these decisions." 239 They "would much prefer to spend their time in nonpolitical pursuits." 240 Nor are they particularly keen on the idea of their fellow Americans ruling. "People overwhelmingly admit that they and the American people generally are largely uninformed about political matters," Hibbing and Theiss-Morse report. ${ }^{241}$ "They also

236 de Tocqueville, 1 Democracy in America at 267 (cited in note 64).

237 Kaufman, Participatory Democracy at 209 (cited in note 233). Kaufman cites Michael Walzer, A Day in the Life of a Socialist Citizen, Dissent (May-June 1968), who, in turn, references Oscar Wilde.

238 See Hibbing and Theiss-Morse, Stealth Democracy at 246-54 (cited in note 234) (describing their methodology, including a survey of 1,266 nationally representative respondents and 8 focus-group sessions).

239 Id at 1 . These are generalizations, of course. To be sure, "some ordinary Americans love the give and take of politics," but "because politicized citizens make more noise, and because political writers themselves are smitten with politics and care about issues, the number of "politicos' in the general population has been grossly overestimated." Id at 11 . See also Herbert, Citizens, Cops and Power at 13 (cited in note 208) (finding that "[u]rban residents do not typically wish for their neighborhoods to act in a politically robust manner").

240 Hibbing and Theiss-Morse, Stealth Democracy at 2 (cited in note 234). See also Robert A. Dahl, Who Governs? Democracy and Power in an American City 305 (Yale 1961) ("In liberal societies, politics is a sideshow in the great circus of life."); Jerome H. Skolnick, The Berkeley Scheme: Neighborhood Police, 212 The Nation 372, 373 (1971) (criticizing neighborhood policing advocates for assuming "that people, especially poor people, have all kinds of free time and public interest").

241 Hibbing and Theiss-Morse, Stealth Democracy at 126 (cited in note 234). 
have reservations about the trustworthiness of the American people" and are "not at all certain that the "country would be better off if the American people rather than politicians decided important political matters." 242

The governance Americans want, instead, is what Hibbing and Theiss-Morse call "stealth democracy": people want democracy "to exist but not to be visible on a routine basis." 243 That said, the only thing Americans dislike more than "a political system built on sustained public involvement" is "a political system in which decision makers-for no reason other than the fact that they are in a position to make decisions-accrue benefits at the expense of non-decision makers." 244 "They are therefore left with a dilemma": they "want to turn political matters over to somebody else because they do not want to be involved themselves, but they do not want to turn decision making over to someone who is likely to act in a selfish, rather than other-regarding, manner." ${ }^{445}$ The upshot is that "people are surprisingly smitten with the notion of elite experts making choices-provided those experts have nothing to gain from selecting one option over another."246

b) Criminal justice exceptionalism? Of course, even if Hibbing and Theiss-Morse are right in general, it is possible that criminal justice is the exception to the rule. Judge Bibas tells us that, unlike in other areas of government where "rational apathy and faith in expertise leads voters to defer to experts . . . many ordinary citizens do not defer to criminal justice experts but show

242 Id. More sharply: "People themselves believe that people aren't very bright, they don't care, they are lazy, they are selfish, they want to be left alone, and they don't want to be informed." Id at 127 .

243 Id at 2. See also Bernard E. Harcourt, The Invisibility of the Prison in Democratic Theory: A Problem of "Virtual Democracy", 23 Good Socy 6, 11-14 (2014) (elaborating a descriptive theory of "virtual democracy," in which the state operates without the full participation of its citizens and responsibility is projected onto politicians and experts).

244 Hibbing and Theiss-Morse, Stealth Democracy at 2 (cited in note 234). This, Hibbing and Theiss-Morse argue, explains Americans' apparent support for direct democracy: "People indicate greater enthusiasm for more political involvement when popular democracy is presented as the only alternative to dominance by self-serving elites." Id at 130 (emphasis added).

245 Id at $85-86$.

246 Id at 86. See id at 141 ("Contrary to conventional wisdom, people like the concept of objective bureaucrats making their technical decisions."). For evidence that "stealth democracy" retains explanatory power today, roughly fifteen years after Hibbing and TheissMorse first wrote, see John R. Hibbing and Elizabeth Theiss-Morse, A Surprising Number of Americans Dislike How Messy Democracy Is. They Like Trump. (Wash Post, May 2, 2016), online at https://www.washingtonpost.com/news/monkey-cage/wp/2016/05/02/a-surprising -number-of-americans-dislike-how-messy-democracy-is-they-like-trump (visited Feb 19, 2020) (Perma archive unavailable). 
passionate interest in how insiders handle criminal cases." 247 "The public is hungry to see and understand criminal justice," he insists, "as shown by its insatiable appetite for crime dramas, news stories, and even reality-television courtroom coverage." 248 It is certainly true that, especially in recent years, public interest in criminal justice is high. Internet searches and media coverage of police misconduct spiked after the deaths of Michael Brown and Eric Garner, for example. ${ }^{249}$ Black Lives Matter is now a household name.

Yet what Hibbing and Theiss-Morse find as a general matter does appear to hold in the criminal justice setting. Attendance at community-policing and community-prosecution meetings, for example, has consistently disappointed over the long run. ${ }^{250}$ An evaluation of community policing programs in eight cities found that all eight encountered great difficulty in cultivating and maintaining community involvement. ${ }^{251}$ This "low level of citizen participation," in turn, "is detrimental to police departments' programmatic efforts.”252

247 Bibas, Machinery of Criminal Justice at xvii (cited in note 12).

$248 \mathrm{Id}$ at 35.

249 Aurélie Ouss and John Rappaport, Is Police Behavior Getting Worse? Data Selection and the Measurement of Policing Harms, J Legal Stud *1 (forthcoming), archived at https://perma.cc/G3E7-TREN.

250 See Correia, Citizen Involvement at 54-58 (cited in note 207); Goldstein, Policing a Free Society at 146 (cited in note 231); Skogan, et al, Community Policing in Chicago at ii-iii (cited in note 232); William Lyons, Partnerships, Information and Public Safety: Community Policing in a Time of Terror, 25 Policing: Intl J Police Strategies \& Mgmt 530, 534 (2002); Wesley G. Skogan, Why Reforms Fail, 18 Policing \& Socy 23, 31 (2008).

251 See Randolph M. Grinc, "Angels in Marble”: Problems in Stimulating Community Involvement in Community Policing, 40 Crime \& Deling 437, 465 (1994).

252 Correia, Citizen Involvement at 10 (cited in note 207). Take Chicago's community policing program, for example. Around the end of the twentieth century, community policing in Chicago, with its well-attended beat meetings, was thought to exemplify "empowered participation" in local governance. See Fung, Empowering Participation at 2-5 (cited in note 112); Robert E. Worden and Sarah J. McLean, Mirage of Police Reform: Procedural Justice and Police Legitimacy 26 (California 2017) (asserting that community policing was "implemented as a strategic reform . . . in Chicago as much as (and probably more than) it was in any other city"). On a longer view, however, this early success was a flash in the pan. Critically, Chicago had been spending millions to run its meetings and promote attendance. See Wesley G. Skogan, et al, Taking Stock: Community Policing in Chicago *8 (National Institute of Justice, 2002), archived at https://perma.cc/49NJ-RHSV. Experts wondered even then whether that level of funding was sustainable. It wasn't. In the early 2000s, "[m]oney was pulled away . . and never returned." Nissa Rhee, Manny Ramos, and Andrea Salcedo, The Rise and Fall of Community Policing in Chicago, Chi Reader (Sept 22, 2016), archived at https://perma.cc/4YWU-VKCG. Attendance waned. See Skogan, et al, Community Policing in Chicago at ii-iii (cited in note 232) (reporting that, by 2002, beat meetings had gotten shorter, fewer officers were attending, and satisfaction among attendees was declining); Rhee, Ramos, and Salcedo, The Rise and Fall of Community 
To be sure, public preferences to participate are endogenous to the system-perhaps people don't want to participate because, under current conditions, participation is unfulfilling. Improve the system, the argument might go, and preferences will change. Maybe. ${ }^{253}$ But we've been trying community policing-including the sorts of civilian review and advisory boards the democratizers suggest-for over thirty years. Why should we not think this is as good as it gets? Of course, it is possible that what people want is not more meetings but rather a practice of ongoing engagement between the police and civilians on the terms of the latter, not the former. If so, the democratizers should prioritize constructing this new model. Still, Hibbing and Theiss-Morse (and others) give reason for continued skepticism: "people want to distance themselves from government," they report, "not because of a system defect but because many people are simply averse to political conflict and many others believe political conflict is unnecessary and an indication that something is wrong with governmental procedures." 254

c) Mandatory participation. Perhaps people need a nudge to awaken the participatory spirit. Jury service, of course, is mandatory. Adding additional juries-for bail, pleas, sentencing, and so on-would require only expanding the current system. We could likewise require participation on civilian advisory committees or review boards or attendance at neighborhood beat meetings. In reality, however, it's not so simple: the national yield on jury summonses is less than 50 percent 255 and far less in some

Policing in Chicago (cited in note 252) (noting sharply declining attendance after 2000). Community policing was said to have failed the city's Latinos, in particular, due to their insufficient "commitment" to participating in the program. See Wesley G. Skogan and Lynn Steiner, Crime, Disorder and Decay in Chicago's Latino Community, 2 J Ethnicity Crim Just 7, 25 (2004).

253 See generally Michael A. Neblo, Kevin M. Esterling, and David M.J. Lazer, Politics with the People: Building a Directly Representative Democracy (Cambridge 2018).

254 Hibbing and Theiss-Morse, Stealth Democracy at 7 (cited in note 234). See also generally Nina Eliasoph, Avoiding Politics: How Americans Produce Apathy in Everyday Life (Cambridge 1998); Samara Klar, Yanna Krupnikov, and John Barry Ryan, Affective Polarization or Partisan Disdain? Untangling a Dislike for the Opposing Party from a Dislike of Partisanship, 82 Pub Op Q 379 (2018). See also Mansbridge, Beyond Adversary Democracy at 273 (cited in note 192); Diana C. Mutz, Hearing the Other Side: Deliberative Versus Participatory Democracy 3 (Cambridge 2006); Stacy G. Ulbig and Carolyn L. Funk, Conflict Avoidance and Political Participation, 21 Pol Behav 265, 276 (1999).

255 Gregory E. Mize, Paula L. Hannaford-Agor, and Nicole L. Waters, The State-ofthe-States Survey of Jury Improvement Efforts: Executive Summary *5 (Center for Jury Studies 2007), archived at https://perma.cc/UWS7-LL8L. 
large cities. ${ }^{256}$ Younger adults who have childcare responsibilities or are starting careers are especially reluctant to serve; so are individuals of lower socioeconomic status and some communities of color. ${ }^{257}$ But setting that aside, there could be benefits to expanding mandatory service-intrinsic benefits irrespective of criminal justice outcomes. Some research has found that jury service promotes voting and other forms of political engagement.258 Over time, in fact, grudging, mandatory service might naturally morph into widespread volunteerism.

It is worth asking: If the point of democratization is to effectuate the people's will, do we accomplish this by forcing people to participate against their will?259 Put differently, the democratizers focus on effectuating the laity's substantive views on criminal justice policy, but people have preferences for process as wellindeed, much clearer preferences, according to Hibbing and Theiss-Morse 260 - and the two may be at odds. True, a little bit of forced participation now might change public preferences for process in the future. But this smacks of a certain paternalism incongruous with the democratizers' own conception of democratic rule. Given that most people do not want more responsibility for political decision-making, nor to give that responsibility to the rest of public, which approach actually implements what the people

256 See, for example, Susan Carol Losh and Robert G. Boatright, Life-Cycle Factors, Status, and Civic Engagement: Issues of Age and Attitudes Toward Jury Service, 23 Just Sys J 221, 222 (2002) (reporting that, in New York City and Los Angeles, only around 10 percent of summoned jurors reported); Richard Seltzer, The Vanishing Juror: Why Are There Not Enough Available Jurors?, 20 Just Sys J 203, 216 (1999) (finding that 20 percent of DC jurors ignored summonses and 35 percent did not receive them).

257 See, for example, Andrew J. Bloeser, Carl McCurley, and Jeffery J. Mondak, Jury Service as Civic Engagement: Determinants of Jury Summons Compliance, 40 Am Polit Rsrch 179, 189 (2012) (finding that 46 percent of Washington State jurors complied with summonses but only half as many Latinos and Asians did so).

258 See generally John Gastil, et al, Jury Service and Electoral Participation: A Test of the Participation Hypothesis, 70 J Polit 351 (2008); John Gastil and Phillip J. Weiser, Jury Service as an Invitation to Citizenship: Assessing the Civic Value of Institutionalized Deliberation, 34 Pol Stud J 605 (2006).

259 See Russell Hardin, Deliberation: Method, Not Theory, in Macedo, ed, Deliberative Politics 103, 112 (cited in note 228) ("It is hard to avoid the suspicion that deliberative democracy is the 'democracy' of elite intellectuals" that "will work, if at all, only in parlor room discourse or in the small salons of academic conferences."); Daniel A. Bell, Democratic Deliberation: The Problem of Implementation, in Macedo, ed, Deliberative Politics 70, 75 (cited in note 228) (asserting that "ordinary citizens would not recommend solving political problems by means of deliberation"), citing Lynn M. Sanders, Against Deliberation, 25 Pol Theory 347, 348 (1997).

260 See Hibbing and Theiss-Morse, Stealth Democracy at 13 (cited in note 234). 
want-one that forces them to participate nonetheless or one that respects their preference to put the experts in charge?

To say that there are social benefits to jury service and possibly other forms of criminal justice engagement, moreover, is not to say there aren't countervailing costs. Again, group deliberation can reinforce hierarchy and cause discomfort. Some jurors walk away feeling frustrated or disenchanted. Jury service is stressful and some jurors, particularly those who hear violent or disturbing matters, actually experience adverse health effects. ${ }^{261}$ The costs to individuals who are called but not seated are substantial as well. ${ }^{262}$ Overall, the annual total social cost of the jury system is probably in the billions. 263 The point is not that there are no benefits to the jury system; only that, before expanding it, we should consider the costs as well.

Finally, even assuming the intrinsic benefits of "mandatory" public participation do outweigh the costs, one might still ask whether this - the criminal justice process-is the optimal site for engagement. At least some of the democratizers see value in members of the community expressing their collective condemnation of criminal wrongdoers. ${ }^{264}$ I am more skeptical. Participating

261 For a review of the relevant literature, see generally Michelle Lonergan, et al, Prevalence and Severity of Trauma- and Stressor-Related Symptoms Among Jurors: A Review, 47 J Crim Just 51 (2016). See also generally Daniel W. Shuman, et al, The Health Effects of Jury Service, 18 L \& Psych Rev 267 (1994).

262 See, for example, Gastil, et al, The Jury and Democracy at 66 (cited in note 65) (reporting that many non-seated prospective jurors "perceived their time to have been wasted"); Joanna Sobol, Note, Hardship Excuses and Occupational Exemptions: The Impairment of the "Fair Cross-Section of the Community", 69 S Cal L Rev 155, 158-59 (1995). This describes a huge number of potential jurors. See Susan Saulny, Jury Duty? Prepare for Rejection; Though Many Are Called, Few Ever Deliberate (NY Times, Sept 8, 2003), archived at https://perma.cc/ATT3-TVD3 ("In New York State, 82 percent of the people called for jury service never make it past voir dire.").

263 See Donald L. Martin, The Economics of Jury Conscription, 80 J Pol Econ 680, 684 tbl 1, 700-01 appx (1972) (estimating the annual social cost of the jury system at $\$ 232.9$ million in 1962 dollars, which is over $\$ 2$ billion in 2019 dollars, though trial rates and the nature of jury trials have changed).

264 See, for example, Bibas, Machinery of Criminal Justice at 49-50 (cited in note 12) (arguing, among other things, that punishment "reaffirms society's norms"). 
in punishment has real downsides, ${ }^{265}$ and its upsides may be overstated. ${ }^{266}$ Why not mandatory community service instead? The bottom line is that, even if there are net intrinsic benefits to lay participation in criminal justice, criminal justice is not the only game in town, and the net benefits of lay participation in other societal activities may be even greater.

\section{Externalities.}

To this point, I have focused on the ways in which individuals in our society are less interconnected, and less interested in connection, than the democratizers seem to think. In an important respect, however, the opposite is simultaneously true. The democratizers' vision of an America in which neighborhoods make and implement criminal justice policy reflective of shared values and local conditions ignores the critical ways in which neighborhoods themselves are interconnected. What one neighborhood does about crime affects the neighborhoods around it in ways that are not incidental but structural. 267 "The particular behaviors and persons targeted by quality of life or exclusionary zoning ordinances," for example, "will not disappear; they will just go somewhere else, to increasingly marginalized, coerced, and isolated spaces." 268 "Displacement," one commentator poignantly writes, "is thus the central birth act of community." 269

This is not to say that displacement is an inevitable byproduct of all policing strategies, no matter how carefully executed. Indeed, the empirical evidence suggests that "focused deterrence" strategies-which aim "to change offender behavior by understanding underlying crime-producing dynamics and conditions

265 See Martha C. Nussbaum, Anger and Forgiveness: Resentment, Generosity, Justice 5-6 (Oxford 2016) (outlining reasons that "anger is always normatively problematic, whether in the personal or in the public realm"); Tonry, Thinking About Crime at 201 (cited in note 40) (arguing that the desire to punish is an expression of anger). See also Eric Klinenberg, Bowling Alone, Policing Together, 28 Soc Just 75, 80 (2001) ("[T]he elevation of policing into a mode of social integration marks a disturbing trend toward a society where distrust, suspicion, and fear are organizing principles of politics and culture.").

266 See generally, for example, Marilyn Peterson Armour and Mark S. Umbreit, Assessing the Impact of the Ultimate Penal Sanction on Homicide Survivors: A Two State Comparison, 96 Marq L Rev 1 (2012) (finding that capital punishment does not improve survivors' well-being).

267 Schragger, 100 Mich L Rev at 422 (cited in note 207).

268 Id at 427.

269 Id. See also Dennis P. Rosenbaum, The Limits of Hot Spots Policing, in David Weisburd and Anthony A. Braga, eds, Police Innovation: Contrasting Perspectives 245, 252-53 (Cambridge 2006). 
that sustain recurring crime problems and by implementing an appropriately focused blended strategy of law enforcement, community mobilization, and social service actions"-can reduce crime without significant displacement. ${ }^{270}$ The policing programs evaluated in the focused deterrence literature, however, warrant study precisely because they are exceptional. More typical forms of American policing, in contrast, may well displace crime-one review, for example, found "considerable evidence of spatial displacement of calls or crime incidents as a result of police crackdowns, especially during drug enforcement." 271

Displacement of crime, moreover, coupled with jurisdictional competition, may actually create an "arms race between local communities attempting to drive crime to their neighbors," resulting in an upward spiral of enforcement and sanctions. ${ }^{272}$ Affluent communities are most likely to come out on top. ${ }^{273}$ These negative externalities are easy to miss if we think about only our own "community" when formulating policy, as the adversely affected individuals are, by definition, "outsiders" to that community. ${ }^{274}$ Yet they create real tension within the participatory democratic agenda, as these same "outsiders," precisely because of their outsider status, have no voice in the decisions to adopt the policies that affect them. ${ }^{275}$

The democratizers' plan to devolve power to increasingly small neighborhood jurisdictions will only exacerbate this problem. The smaller the geographic unit that controls criminal punishment, the shorter the distances between the interiors of different units, which makes it easier for potential offenders to travel among relevant jurisdictions and therefore to select among jurisdictions in which to commit crime. The smaller the jurisdiction, in other words, the greater the payoff from raising punishment to displace crime.

270 Anthony A. Braga, David Weisburd, and Brandon Turchan, Focused Deterrence Strategies and Crime Control: An Updated Systematic Review and Meta-Analysis of the Empirical Evidence, 17 Crimin \& Pub Pol 205, 206, 237-38 (2018).

271 Rosenbaum, The Limits of Hot Spots Policing at 253 (cited in note 269).

272 See Doron Teichman, The Market for Criminal Justice: Federalism, Crime Control, and Jurisdictional Competition, 103 Mich L Rev 1831, 1834 (2005).

273 See Herbert, Citizens, Cops, and Power at 59, 146 (cited in note 208).

274 See Schragger, 100 Mich L Rev at 422 (cited in note 207).

275 See id at $444-45$. 


\section{B. Lay Leniency}

The democratizers insist that, properly understood, people are basically lenient, or at least no less so than criminal justice professionals. This premise motivates their prescription of democratization as a palliative for mass incarceration. To be sure, the democratizers readily concede that, when surveyed on "wholesale" policy issues in general public opinion polls, laypeople have long expressed punitive sentiments, including that sentences are too lenient. They urge us, however, not to infer too much from these results. Moreover, sentiments tend to soften at the "retail" level, in particular cases. This Section responds to these points in detail.

1. Wholesale leniency.

General opinion polls, the democratizers insist, capture only "top of the head" opinions rather than informed, reflective judgments. These opinions, too, are cultivated by political elites; they do not preexist in the polity. The same thing explains punitive public referenda. What is more, the image of a punitive public is increasingly outdated. In fact, public attitudes have been softening since the mid-1990s.

a) Reflexive opinions. All agree that, from the 1970s through at least the mid-1990s, Americans expressed generally punitive penal policy opinions. ${ }^{276}$ The public firmly supported the death penalty, ${ }^{277}$ three-strikes laws, ${ }^{278}$ and mandatory minimum

276 See, for example, Peter K. Enns, Incarceration Nation: How the United States Became the Most Punitive Democracy in the World 38 (Cambridge 2016); Julian V. Roberts and Loretta J. Stalans, Public Opinion, Crime, and Criminal Justice 207 (Westview 1997). See also Francis T. Cullen, Bonnie S. Fisher, and Brandon K. Applegate, Public Opinion About Punishment and Corrections, 27 Crime \& Just 1, 26-27, 38 (2000); Douglas R. Thomson and Anthony J. Ragona, Popular Moderation Versus Governmental Authoritarianism: An Interactionist View of Public Sentiments Toward Criminal Sanctions, 33 Crime \& Delinq 337, 338 (1987); Michael G. Turner, et al, Public Tolerance for Community-Based Sanctions, 77 Prison J 6, 7 (1997); Vesla M. Weaver, Frontlash: Race and the Development of Punitive Crime Policy, 21 Stud Am Pol Dev 230, 264 fig 9 (2007).

277 See, for example, Beckett, Making Crime Pay at $80 \&$ n 5 (cited in note 126); Enns, Incarceration Nation at 25-26, 35 (cited in note 276).

278 Voters in Washington State's 1993 referendum on a "three-strikes" statute approved the measure by a three-to-one margin. Cullen, Fisher, and Applegate, 27 Crime \& Just at 38 (cited in note 276). In a 1994 referendum, 72 percent of voters supported California's "three-strikes" law. Id. 
sentences. ${ }^{279}$ They consistently regarded judicial sentences as unduly lenient.280 All agree as well that the public is deeply uninformed about the criminal justice system. ${ }^{281}$ One particularly telling misapprehension is that people believe crime is rising even when it's been declining for years. ${ }^{282}$ Confronted with widespread lay ignorance, some scholars conclude that public opinions on wholesale criminal justice policies are simply meaningless. ${ }^{283}$

Others, however, call for public education. ${ }^{284}$ Studies using focus groups and surveys have found that participants become less punitive when they are educated about alternatives to, ${ }^{285}$ or the costs of, 286 incarceration. Some scholars contend, based on these findings, that the public's "true" judgments can be revealed only by sampling informed participants. ${ }^{287}$ In this vein, democratizers committed to reducing incarceration might figure that educating

279 See, for example, id at 38; Stalans and Diamond, 14 L \& Hum Behav at 200 (cited in note 135)

280 From the first administration of the nationwide General Social Survey in 1972 through 1994, the percentage of respondents reporting that local courts are too lenient rose from 65 percent to 85 percent, fluctuating between 80 percent and 87 percent from 1976 through 1994. GSS Data Explorer, online at https://gssdataexplorer.norc.org/trends/ Civil\%20Liberties?measure=courts (visited Feb 19, 2020) (Perma archive unavailable). An almost identical question asked on the Gallup poll yielded similarly punitive results beginning in the 1970s, see Enns, Incarceration Nation at 35 (cited in note 276), and lasting through 1992, see Justin McCarthy, Americans' Views Shift on Toughness of Justice System (Gallup, Oct 20, 2016), archived at https://perma.cc/BW7X-BAKH.

281 For a catalog of the public's misperceptions, see Julian V. Roberts, Public Opinion, Crime, and Criminal Justice, 16 Crime \& Just 99, 109-16 (1992).

282 See, for example, Michael T. Costelloe, Ted Chiricos, and Marc Gertz, Punitive Attitudes Toward Criminals: Exploring the Relevance of Crime Salience and Economic Insecurity, 11 Punishment \& Soc 25, 27 (2009); Justin McCarthy, Most Americans Still See Crime Up over Last Year (Gallup, Nov 21, 2014), archived at https://perma.cc/8WZM-99M3.

283 See Stalans and Diamond, 14 L \& Hum Behav at 200 (cited in note 135). See also Judith Greene and John Doble, Attitudes Towards Crime and Punishment in Vermont: Public Opinion About an Experiment with Restorative Justice 4-5, 9-10 (National Institute of Justice, 2000), archived at https://perma.cc/2HLR-33J5.

284 See Julian V. Roberts, American Attitudes About Punishment: Myth and Reality, in Michael Tonry and Kathleen Hatlestad, eds, Sentencing Reform in Overcrowded Times: A Comparative Perspective 250, 254-55 (Oxford 1997).

285 See John Doble and Josh Klein, Punishing Criminals, The Public's View: An Alabama Survey 38 (Edna McConnell Clark Foundation 1989); Michael Hough and Julian Roberts, Attitudes to Punishment: Findings from the British Crime Survey 29 (Home Office Research \& Statistics Directorate, 1998), archived at https://perma.cc/4V67-XX3G.

286 See Thomson and Ragona, 33 Crime \& Delinq at 350 (cited in note 276).

287 See, for example, Jan W. de Keijser, Penal Theory and Popular Opinion: The Deficiencies of Direct Engagement, in Jesper Ryberg and Julian V. Roberts, eds, Popular Punishment: On the Normative Significance of Public Opinion 101, 107 (Oxford 2014); David A. Green, Public Opinion Versus Public Judgment About Crime: Correcting the "Comedy of Errors”, 46 Brit J Crimin 131, 150 (2006). 
the public will minimize the risk that lay participation will effectuate punitive views.

There is more than an ounce of hypocrisy in this position. Consider how the democratizers know that the public view is uninformed: because the democratizers themselves are elites whose study of the criminal justice system gives them specialized knowledge. The democratizers favor the preferences of the public, that is, only so long as the public is, in their own expert assessment, "informed." And who decides what information to give the public before eliciting their views? Some "elite" with expertise on the topic. Which elite, then, may go far toward determining the content of public judgment-learning does not inevitably cut toward leniency. If people are informed that many death row inmates committed murders while on probation, for instance, they may become more punitive, not less. ${ }^{288}$

There are additional reasons to be pessimistic about basing criminal justice policy on "informed" public views. First, other research indicates that public opinion on criminal justice affairs may be "much more fixed and inflexible" than just portrayed, as it is "largely rooted in certain fairly stable underlying social psychological predispositions," such as "sociopolitical ideology and racial prejudice." 289 "Given the sources of these attitudes, and the fact that political and social values are developed early in life and are rather stable," this research suggests, "it is likely that views on the criminal justice system are rather rigid and resistant to change." 290 The truth may be somewhere in the middle: public opinion may be fixed with respect to some issues but not others, and different factions of the public may differ in this regard. ${ }^{291}$

Second, the sort of mass public education campaign that would be necessary to alter widely held public attitudes simply isn't feasible. Written materials and presentations are likely inadequate; proponents advocate admittedly "utopian" mechanisms like deliberative polls, consensus conferences, study circles, and planning cells. ${ }^{292}$ There is also some evidence that, even when successfully altered, lay attitudes revert back to their "pre-informed"

288 See Cullen, Fisher, and Applegate, 27 Crime \& Just at 44-45 (cited in note 276); Turner, et al, 77 Prison $J$ at 8 (cited in note 276).

289 Lawrence D. Bobo and Devon Johnson, A Taste for Punishment: Black and White Americans' Views on the Death Penalty and the War on Drugs, 1 Du Bois Rev 151, 155 (2004). 290 Id.

291 See id at $170-71$.

292 See Green, 46 Brit J Crimin at 147, 150 (cited in note 287). 
state. ${ }^{293}$ Penal policies based on the preferences of a curated and ephemeral "informed" public therefore will not reflect the preferences of the public at large. ${ }^{294}$ In short, it is likely unwise to "dismiss global attitudes as somehow 'wrong' or based on misperceptions," as even "general polling questions are measuring something," 295 if nothing more than a "general propensity that underlies many people's thinking." ${ }^{296}$

b) Elite influence. Nor should the notion that political elites manipulate public opinion provide much comfort about the content of "true" public attitudes toward punishment. Professor Katherine Beckett, the principal authority cited for this proposition, finds that when politicians focus more attention on crime, public concern about crime increases. ${ }^{297}$ Beckett's research design, however, has serious limitations. First, as Beckett herself notes, concern about crime does not necessarily generate punitive attitudes. ${ }^{298}$ Second, Beckett's measure of public concern is coarse, using the percentage of respondents who rank crime as the "most important problem facing the nation." ${ }_{299}$ Her principal finding, therefore, may mean only that political attention promotes crime from, say, the public's second-most-important issue to its firstmost-important concern. And a lot depends on the status of other issues, such as the economy. During a recession, for example, worries about the economy may eclipse fears about crime; when the recession ends, economic concerns may recede, creating the appearance of rising (relative) concern about crime even if underlying attitudes toward crime are unchanged. 300

More recent scholarship rejects the theory that politicians create rather than follow the public's punitive views. Political scientist Peter Enns reviews archival and public opinion data from the 1960s and concludes that "the evidence overwhelmingly suggests that political elites" in that signal era "responded to the

293 See de Keijser, Penal Theory and Popular Opinion at 106-07 (cited in note 287).

294 See id at 107-09.

295 Applegate, et al, 42 Crime \& Delinq at 530 (cited in note 133) (emphasis added).

296 Cullen, Fisher, and Applegate, 27 Crime \& Just at 58 (cited in note 276).

297 See, for example, Beckett, Making Crime Pay at 15 (cited in note 126) ("[L]evels of public concern are largely unrelated to the reported incidence of crime and drug use but are strongly associated with the extent to which elites highlight these issues in political discourse."). For consonant accounts, see Mark D. Ramirez, Punitive Sentiment, 51 Crimin 329, 333-34 (2013); Weaver, 21 Stud Am Pol Dev at 232 (cited in note 276).

298 See Beckett, Making Crime Pay at 25-26 (cited in note 126).

299 Id at 16 \& n 11.

300 See Enns, Incarceration Nation at 21 (cited in note 276). 
public's shifting support for being tough on crime." ${ }^{01}$ In a series of regressions, Enns then explores the relationship among public opinion data, crime reports in the media, political attention to crime, and changes in the incarceration rate. Refining Beckett's "most important problem" proxy for public attitudes about punishment, Enns constructs a composite measure of public punitiveness from twenty-six survey questions assessing "attitudes toward the treatment of criminals, the death penalty, spending to prevent crime, and lack of confidence in the police and the criminal justice system." ${ }^{302}$ He finds that "[c]rime rates appear to influence news coverage, which influences the public's punitiveness, which influences government action"-and that public punitiveness predicts the incarceration rate. ${ }^{303}$ Other recent work similarly concludes that public views are more influential than political ones in retaining the death penalty ${ }^{304}$ and that federal criminal justice policy responds to public punitiveness but not to "elite attention to crime." ${ }^{05}$ All of this evidence tends to validate those who have attributed harsh penal policies like three-strikes laws to the forces of penal populism. 306

$301 \mathrm{Id}$ at 68 .

302 Id at 33-37.

303 Id at 95, 114-18. See also John F. Pfaff, Locked In: The True Causes of Mass Incarceration and How to Achieve Real Reform 176 (Basic Books 2017) (concluding that, due to methodological improvements, Enns's findings are more persuasive than Beckett's); John Clegg and Adaner Usmani, The Racial Politics of the Punitive Turn *7 n 3 (unpublished manuscript, Aug 2018) (on file with author) (similar). Not everyone agrees that crime rates drive public concern with crime or public punitiveness. This skeptical view usually traces back to Beckett, though there is some more recent research to this effect as well. See, for example, Gary Kleck and Dylan Baker Jackson, Does Crime Cause Punitiveness?, 63 Crime \& Delinq 1572, 1584 (2017).

304 See David Jacobs and Jason T. Carmichael, The Political Sociology of the Death Penalty: A Pooled Time-Series Analysis, 67 Am Sociological Rev 109, 126-27 (2002).

305 Sean Nicholson-Crotty, David A.M. Peterson, and Mark D. Ramirez, Dynamic Representation(s): Federal Criminal Justice Policy and an Alternative Dimension of Public Mood, 31 Pol Behav 629, 650 (2009). Professor Mark Ramirez finds that presidential framing of crime influences punitive public sentiment, though the effect is smaller than, say, that of "public perceptions that racial integration is increasing." Ramirez, 51 Crimin at 348-49 (cited in note 297). Using Ramirez's data, Enns finds some evidence consistent with Ramirez but also finds that the opposite relation-that public sentiment influences presidential framing - is more likely. See Enns, Incarceration Nation at 95-96 (cited in note 276). Enns also argues that, even if political elites sometimes influence public attitudes, they "face strong incentives to follow the public and are unlikely to be able to lead the public for extended periods of time." Id at 51.

306 See note 40. See also Barkow, Prisoners of Politics at 105 (cited in note 41) ("[T]he shift to mass incarceration is directly linked to the shift from leaving judgments to professionals to allowing the masses to set policies directly."). 
c) Outdated perspectives. It is sometimes said that we are in the midst of a criminal justice "moment," when public attitudes have softened and the possibilities for reform have opened up. ${ }^{307}$ Indeed, the data suggest we've been on this path for some time. Beginning in the mid-1990s, the public's punitiveness, as measured by general policy questions, began-along with crime rates, notably - to decline. ${ }^{308}$ National polls, surveys, and referenda document the public's declining support for the death penalty, ${ }^{309}$ increasing belief that courts are too harsh, ${ }^{310}$ and rising rejection of mandatory minimums. ${ }^{311}$ In addition, some progressive criminal justice policies — such as reducing penalties for nonviolent crimes and drug offenses, ${ }^{312}$ providing rehabilitative services for convicted offenders, ${ }^{313}$ and favoring "root cause" over "get tough" approaches to crime ${ }^{314}$ — currently enjoy high levels of public support. Perhaps because they seek to discount the importance of public attitudes when those attitudes are punitive, the democratizers don't give this point a lot of ink. Still, it's hard to shake the sense that optimism flowing from recent attitudinal shifts permeates the democratization agenda.

Yet several points of caution are in order. First, while public opinion is certainly less punitive today than it was three decades

307 See, for example, Ghandnoosh, Race and Punishment at *5 (cited in note 6); Beth Schwartzapfel, The States Where Voters Decided to Give Criminal Justice Reform a Try (Marshall Project, Nov 9, 2016), archived at https://perma.cc/X74Q-R98Z.

308 See Enns, Incarceration Nation at 38, 162 (cited in note 276).

309 See Jeffrey M. Jones, U.S. Death Penalty Support Lowest Since 1972 (Gallup, Oct 26, 2017), archived at https://perma.cc/CVG4-6FW3. See also Jill Mizell, An Overview of Public Opinion and Discourse on Criminal Justice Issues *35-36 (Opportunity Agenda, 2014), archived at https://perma.cc/K5W8-7JP6.

310 Belief that the courts are too harsh has increased or remained constant almost every year since 1994. See GSS Data Explorer (cited in note 280).

311 See Mizell, An Overview of Public Opinion at 35 (cited in note 309); Peter D. Hart Research Associates, Inc, Changing Public Attitudes Toward the Criminal Justice System *5 (Open Society Institute, Feb 2002), archived at https://perma.cc/K4Z4-8S7E; Cheryl A. Roberts, et al, Rethinking Justice in Massachusetts: Public Attitudes Toward Crime and Punishment *14 (Crime \& Justice Institute and Doble Research Associates, Nov 3, 2005), archived at https://perma.cc/F2R5-ETHE.

312 See Mizell, An Overview of Public Opinion at *33-34 (cited in note 309); Peter D. Hart Research Associates, Changing Public Attitudes at*10-12 (cited in note 311).

313 See Francis T. Cullen, et al, Public Support for Correctional Rehabilitation in America: Change or Consistency?, in Julian V. Roberts and Mike Hough, eds, Changing Attitudes to Punishment: Public Opinion, Crime and Justice 128, 137 (Routledge 2002). See also Mizell, An Overview of Public Opinion at 21 (cited in note 309); Peter D. Hart Research Associates, Changing Public Attitudes at *4, 13-14 (cited in note 311).

314 See Mizell, An Overview of Public Opinion at *24 (cited in note 309); Peter D. Hart Research Associates, Changing Public Attitudes at *3 (cited in note 311); Roberts, et al, Penal Populism and Popular Opinion at 13 (cited in note 40). 
ago, at the tail end of a massive crime wave, it remains quite harsh. A majority of the country continues to support the death penalty and still believes that courts are too lenient. ${ }^{315}$ Well under 20 percent of Americans think that prison conditions are too harsh. ${ }^{316}$ And the emergence of seemingly lenient attitudes has not crowded out punitive beliefs. In fact, numerous studies show that the same individuals who support the death penalty and view the courts as too lenient also support rehabilitation and alternative sentences to incarceration. ${ }^{317}$

Second, public support for more lenient policies, such as alternatives to incarceration, is strictly limited to nonviolent offenders. Most would agree that the public still desires long terms of imprisonment for violent offenders. ${ }^{318}$ As more than half of state prisoners are incarcerated for violent offenses, the public's punitive views with respect to violent offenders may swamp their somewhat more lenient views regarding nonviolent offenders. ${ }^{319}$ There is some suggestion, too, that the public may hold a broad view of which offenses are "violent"-respondents in one recent study counted the purchase of a controlled substance as violent "because of aggressive tendencies" they believe accompany the activity. ${ }^{320}$

Last, and most important, even if the public endorses more lenient policies today, that in no way precludes public opinion from veering punitive in the future. Indeed, current trends may simply reflect reversion to the mean. This is a simple but critical point. If Enns is right, it is unsurprising that public punitiveness has declined since the mid-1990s because crime rates have been

315 On the death penalty, see Jones, U.S. Death Penalty Support Lowest Since 1972 (cited in note 309). On judicial leniency, see GSS Data Explorer (cited in note 280). A 2014 study found that 54 percent of Americans believe that "society is better served by harsher punishment for people convicted of crimes" than by efforts to rehabilitate offenders. Mizell, An Overview of Public Opinion at *20 (cited in note 309).

316 See Kevin H. Wozniak, American Public Opinion About Prisons, 39 Crim Just Rev 305,314 (2014).

317 See Cullen, Fisher, and Applegate, 27 Crime \& Just at 133-34 (cited in note 276); John Doble, Attitudes to Punishment in the US: Punitive and Liberal Opinions, in Roberts and Hough, eds, Changing Attitudes to Punishment at 148, 152 (cited in note 313); Turner, et al, 77 Prison J at 7 (cited in note 276).

318 See, for example, James Forman Jr, Locking Up Our Own: Crime and Punishment in Black America 221, 228, 231 (Farrar, Straus and Giroux 2017); Greene and Doble, Attitudes Towards Crime and Punishment in Vermont at 9 (cited in note 283); Mizell, An Overview of Public Opinion at *34 (cited in note 309); Cullen, Fisher, and Applegate, 27 Crime \& Just at 41 (cited in note 276).

319 See Forman, Locking Up Our Own at 230 (cited in note 318); Pfaff, Locked In at 185-202 (cited in note 303).

320 See Mizell, An Overview of Public Opinion at *34 (cited in note 309). 
falling as well. Even those who view the public as generally harsh concede that public punitiveness sometimes recedes. But what happens when crime begins to climb or a sensational offense captures the nation's attention, setting off a moral panic? Circumstances like these have birthed countless punitive laws and nothing has been done to change the political defects that enabled them. ${ }^{321}$ The democratizers propose fundamental-and presumably enduring - changes in system design, not temporary adjustments designed to exploit a possibly fleeting "moment" of public restraint. Their burden is to show that their reimagined system is best for the long run, including the bad times and not just the good.

The public's punitive wholesale attitudes pose problems for various aspects of the democratization agenda. The democratizers want laypeople to "aid legislatures in the process of crafting substantive and procedural criminal law," to advise police departments on "priorities, policies, and informal practices," to collaborate with prosecutors, and to oversee "matters of policy and conditions in jails [and] prisons." ${ }_{22}$ The evidence just reviewed should make us nervous about what policies, exactly, the laity will demand.

\section{Retail leniency.}

Perhaps because of these concerns about public views on wholesale criminal justice issues, a major part of the democratization agenda aims to channel lay participation toward "retail" outlets: adjudication, such as sentencing juries, rather than policymaking. The democratizers rely heavily on research by Professors Robinson, Diamond, and others finding that, when presented with individual case vignettes, laypeople choose sentences more lenient than their wholesale perspectives might suggest. ${ }^{323}$ Even granting some credence to the basic point, I continue to believe that lay severity remains a problem. In fact, on my reading, the

321 See Pfaff, Locked In at 162-63 (cited in note 303). See also Tonry, Thinking About Crime at 85-86 (cited in note 40) (describing the influence of "moral panics" on crime policy); Philip Pettit, Is Criminal Justice Politically Feasible?, 5 Buff Crim L Rev 427, 43637 (2002) (similar). See generally Stanley Cohen, Folk Devils and Moral Panics: The Creation of the Mods and Rockers (Routledge 3d ed 2002).

322 Kleinfeld, et al, $111 \mathrm{Nw}$ U L Rev at 1699 (cited in note 29).

323 Ironically, Robinson himself advocates consideration of lay views of justice for wholesale rather than retail purposes. See Robinson, 111 Nw U L Rev at 1594 (cited in note 92). 
weight of the evidence suggests that the laity is at least as punitive as the courts and bureaucratic professionals, and probably more so.

a) National studies. Since 1980, only three vignette studies, to my knowledge, draw on national samples of the US population. ${ }^{324}$ This is not to suggest that state or local studies are useless, and national studies can mask spatial variation. Still, just as the democratizers propose systemic changes that must function well across time, their program must flourish across space as well. As it turns out, all three of the national studies suggest the public is at least slightly more punitive than the courts.

First, and most recently, a widely cited 2010 article by Robinson and others finds that lay respondents are significantly more punitive than judges. The authors presented respondents with crime vignettes-so-called milestone scenarios-describing offenders committing common offenses that varied widely in severity. ${ }^{325}$ Respondents' sentences were "considerably more punitive than the criminal courts typically are." ${ }^{226}$ In fact, respondents' mean sentences were often double or triple the average time served by real offenders. ${ }^{327}$ The democratizers cite this Robinson study for a different point, discussed below, and ignore this critical finding.

Second, a 1994 study by Professors Peter Rossi, Richard Berk, and Alec Campbell commissioned by the US Sentencing Commission, finds that lay respondents assigned sentences that were, on average, slightly longer than those prescribed by the 1987 Sentencing Guidelines. ${ }^{328}$ Rossi, Berk, and Campbell also note that respondents favored harsher sentences than the Guidelines for less serious offenses and more lenient sentences for graver crimes. 329 They characterize the public as "saying that prison is a proper punishment for the vast majority of federal

324 See Jacoby and Cullen, The Structure of Punishment Norms at 251-52 (cited in note 200) (noting that "virtually all" studies of public punishment preferences use "student, community, or at most, state-wide samples").

325 See Robinson, Goodwin, and Reisig, 85 NYU L Rev at 1962-63 (cited in note 125); Robinson and Kurzban, 91 Minn L Rev at 1867 (cited in note 102).

326 Robinson, Goodwin, and Reisig, 85 NYU L Rev at 1974 (cited in note 125).

327 Id.

328 See Peter H. Rossi, Richard A. Berk, and Alec Campbell, Just Punishments: Guideline Sentences and Normative Consensus, 13 J Quant Crimin 3, 267, 278 (1997).

329 Id at 286. 
crimes, but [that the] very longest sentences prescribed by the guidelines are excessive." 330

Finally, a 1987 study by Joseph Jacoby and Christopher Dunn reports highly punitive sentences by lay respondents. The authors characterize respondents' sentences as "tending to be much longer than sentences actually served currently" across a number of states. ${ }^{331}$ Various researchers have revisited Jacoby and Dunn's data, reaching similar conclusions. One study, for example, compares respondents' preferred sentences to the average time served by offenders in New York. ${ }^{332}$ The authors find that respondents were almost three times more likely than the courts to "impose" prison sentences and "sentenced" offenders to an average of three-and-a-half more years of prison than New York offenders actually served. ${ }^{333}$

b) "Crime control" studies. Where, then, do the democratizers get the idea that laypeople are lenient? Three of the studies most commonly cited for this point actually show, upon closer inspection, only that the public is less punitive than notoriously harsh mandatory sentencing laws. These studies do not show that laypeople are less punitive than the courts would be in the absence of these laws, which many judges also regard as overly punitive. ${ }^{334}$ The first is the 2010 Robinson study discussed above. In addition to the "milestone" vignettes already mentioned, the authors presented respondents with a series of "crime-control" scenarios, in which offenders committed offenses that trigger severe punishment policies such as three strikes, mandatory minimums,

330 Id at 287. Some scholars, moreover, have argued that Rossi, Berk, and Campbell's vignettes, which are based on federal crimes and thus include relatively more white-collar and drug offenses and fewer street crimes, artificially deflate respondents' sentencing severity. See Cullen, Fisher, and Applegate, 27 Crime \& Just 29-31 (cited in note 276).

331 Joseph E. Jacoby and Christopher S. Dunn, National Survey on Punishment for Criminal Offenses: Executive Summary *2 (Bureau of Justice Statistics, 1987), archived at https://perma.cc/P7Z9-WV26.

332 See Sherwood E. Zimmerman, David J. Van Alstyne, and Christopher S. Dunn, The National Punishment Survey and Public Policy Consequences, $25 \mathrm{~J}$ Rsrch Crime \& Delinq 120, 126-29 (1988).

333 See id at 129-31. See also Cullen, Fisher, and Applegate, 27 Crime \& Just at 30 (cited in note 276) (noting respondents' mean (two years) and median (one year) sentences for a $\$ 10$ theft as illustrating preferences for "harsh penalties" for even minor crimes).

334 See, for example, Kate Stith and José A. Cabranes, Fear of Judging: Sentencing Guidelines in the Federal Courts 59-77 (Chicago 1998); Frank O. Bowman III and Michael Heise, Quiet Rebellion? Explaining Nearly a Decade of Declining Federal Drug Sentences, 86 Iowa L Rev 1043, 1134 (2001); Andrew D. Leipold, Why Are Federal Judges So Acquittal Prone?, 83 Wash U L Q 151, 200-18 (2005). 
and felony murder rules. ${ }^{335}$ They find that respondents chose sentences below those dictated by these "crime-control" laws. ${ }^{336}$ Similarly, a 1995 study of Ohio residents found that, although respondents overwhelmingly supported three-strikes legislation in the abstract (88 percent), only a small fraction (17 percent) assigned sentences that were consistent with a three-strikes scheme when given individual vignettes. ${ }^{337}$ Finally, a 1983 study found that only 7 percent of Illinois respondents chose sentences for a residential burglary vignette as long as or longer than the state's statutory minimum sentence. ${ }^{338}$

c) Methodological shortfalls. The democratizers cite additional vignette studies, all of which suffer from serious methodological flaws. Several of the studies, for example, aggregate responses or respondents in ways that preclude any reliable inferences about lay and bureaucratic punitiveness. Judge Bibas describes one widely cited study from California in which, he says, representative respondents given six scenarios "preferred sentences as low as or lower than the typical punishments prescribed by statute." 339 The study's data, however, do not permit this conclusion. Respondents did not select precise sentences; they chose sentencing ranges, and it is impossible to tell what sentence within a particular range various respondents had in mind. When the statutory middle term fell within the range respondents preferred, it is possible the respondents wanted a sentence below the middle term, but—as the study's authors admit in a cautious moment-it is "difficult to be sure." 340 Nor do we know a separate

335 See Robinson, Goodwin, and Reisig, 85 NYU L Rev at 1962-67 (cited in note 125). See also Applegate, et al, 42 Crime \& Delinq at 517, 522 tbl 2, 528-30 \& tbl 4 (cited in note 133).

336 See Robinson, Goodwin, and Reisig, 85 NYU L Rev at 1972-73 (cited in note 125). See also James S. Gwin, Juror Sentiment on Just Punishment: Do the Federal Sentencing Guidelines Reflect Community Values?, 4 Harv L \& Pol Rev 173, 189-91 (2010) (finding that, when polled, actual jurors who had just convicted defendants typically recommended below-Guidelines sentences and noting that a "significant portion of the cases . . . involved either drug possession or distribution or firearm possession," suggesting that jurors' relative leniency was "likely due to the fact that the Guidelines punish drug crimes and felony gun possession harshly").

337 See Applegate, et al, 42 Crime \& Delinq at 525 (cited in note 133). The authors note nonetheless that respondents "did not favor lenient punishment of habitual criminals." Id.

338 See Thomson and Ragona, 33 Crime \& Delinq at 349 (cited in note 276). The authors conclude only that "the public is less vengeful than typically portrayed in public opinion poll and media accounts." Id at 337.

339 Bibas, Machinery of Criminal Justice at 37 (cited in note 12).

340 Samuel and Moulds, 77 J Crim L \& Crimin at 938-39 (cited in note 198). 
crucial fact: how often judges sentence below the middle term. The only relevant conclusion the data actually warrant is that respondents' sentences roughly parallel those in the criminal code. ${ }^{341}$

Multiple external validity concerns plague the vignette studies as well. In some cases, the problems are manifest. A surprising number of the studies cited, for example, involve foreign subjects, who are shown to be no more severe than judges in actual cases. ${ }^{342}$ While Robinson contends that attitudes toward punishment of "core wrongdoings" are "deep, predictable, and widely shared" across cultures, ${ }^{343}$ others have cast serious doubt on that proposition, as already discussed. ${ }^{344}$ Indeed, Kleinfeld himself argues at great length that America's "culture of punishment" is harsher than Europe's. ${ }^{345}$

Some of the most-cited domestic studies are hard to generalize due to sampling bias. In a famous 1987 study by Professors Loretta Stalans and Shari Diamond, for example, only 11 percent of lay respondents assigned a sentence above the statutory minimum. ${ }^{346}$ Judges, too, might have preferred sentences below the minimum, of course. In any event, Stalans and Diamond's sampling technique precludes much, if any, more general conclusion: they found their subjects on a train to Chicago. ${ }^{347}$ In a subsequent study, Diamond and Stalans found that Cook County jurors selected sentences equal to or less severe than Illinois judges in a series of four vignettes. ${ }^{348}$ Critically, all of the jurors resided in

341 See id at 938

342 See, for example, Bibas, Machinery of Criminal Justice at 36 (cited in note 12) (discussing a "set of four Canadian surveys").

343 See Robinson and Kurzban, 91 Minn L Rev at 1892 (cited in note 102).

344 See Braman, Kahan, and Hoffman, 77 U Chi L Rev at 1536-38 (cited in note 195). See also Matthew B. Kugler, et al, Differences in Punitiveness Across Three Cultures: A Test of American Exceptionalism in Justice Attitudes, $103 \mathrm{~J}$ Crim L \& Crimin 1071, 1100-04 (2013) (finding that Americans and Canadians have more punitive attitudes than Germans).

345 See Joshua Kleinfeld, Two Cultures of Punishment, 68 Stan L Rev 933, 1035 (2016). See also Jan van Dijk, John van Kesteren, and Paul Smit, Criminal Victimisation in International Perspective: Key Findings from the 2004-2005 ICVS and EU ICS *148 fig 31 (Wetenschappelijk Onderzoek-en Documentatiecentrum 2007), archived at https://perma.cc/CS7S-9MSP (reporting widely varying punishment preferences for respondents in different nations for a recidivist burglar vignette).

346 See Stalans and Diamond, 14 L \& Hum Behav at 199-203, 206-08 (cited in note 135); Lanni, Note, 108 Yale L J at 1781 n 25 (cited in note 92).

347 See Stalans and Diamond, 14 L \& Hum Behav at 202 (cited in note 135).

348 Diamond and Stalans, 7 Behav Sci \& L at 74-81 (cited in note 142). 
Cook County-the most politically liberal county in the state ${ }^{349}$ while the judges hailed from all over Illinois. This mismatch biased the judicial sample toward relative punitiveness. Indeed, the authors report that Cook County judges were more lenient than judges from elsewhere in the state. ${ }^{350}$

Note, too, the problem, for present purposes, of comparing lay sentencing preferences to the preferences of elected judges, as most of the pertinent studies do. As I will show, elected judgeswho are, or logically should be, preferred by the democratizers to appointed ones-respond to electoral incentives by sentencing more harshly. ${ }^{351}$ Even if elected judges were more punitive than the laity, therefore, the same is not necessarily true of their appointed, more insulated, counterparts.

It may also be misleading to equate lay responses to vignettes with anticipated sentences in real criminal cases. Indeed, this points to an additional external validity concern that permeates all of the vignette studies. According to Robinson, the vignette studies capture what he calls "empirical desert." Empirical desert, reflecting the punishment that laypeople regard as justified, differs from "deontological desert," which is built upon principles of moral philosophy. ${ }^{352}$ But Robinson's empirical desert is "empirical" only in a thin sense. A more accurate characterization, notes Professor Alice Ristroph, is "laboratory desert." 353

The point, of course, is that laboratory vignettes differ meaningfully from actual jury service. "Findings derived from unrealistic simulations should be appropriately qualified," one treatment cautions, "and should not be forwarded as the primary basis for policy changes." 354 Framing effects, time constraints, and even reading comprehension all affect how research subjects respond to laboratory vignettes; ${ }^{355}$ the lack of real-world consequences

349 See, for example, 2016 Illinois Presidential Election Results (Politico, Dec 13, 2016), archived at https://perma.cc/GBE9-B9FK.

350 Diamond and Stalans, 7 Behav Sci \& L at 80-81 (cited in note 142).

351 See Part II.C.2.

352 See Robinson, Goodwin, and Reisig, 85 NYU L Rev at 1943 (cited in note 125).

353 Alice Ristroph, The New Desert, in Robinson, Garvey, and Ferzan, eds, Criminal Law Conversations 45, 48 (cited in note 200) (emphasis omitted).

354 Robert M. Bray and Norbert L. Kerr, Methodological Considerations in the Study of the Psychology of the Courtroom, in Norbert L. Kerr and Robert M. Bray, eds, The Psychology of the Courtroom 287, 318 (Academic 1982).

355 See Alexis M. Durham III, Public Opinion Regarding Sentences for Crime: Does It Exist?, 21 J Crim Just 1, 8-9 (1993) (concluding that, due to factors like these, "public sentiment regarding appropriate sentences for crime is an illusion”). 
may matter as well. ${ }^{356}$ Actual jurors are swayed by what they read in the newspaper ${ }^{357}$ and see in the courtroom. Weapons ${ }^{358}$ and graphic evidence, ${ }^{359}$ for example, can elicit punitive responses. Defendants' races become more salient. 360 Victims garner sympathy. ${ }^{361}$ Judges, of course, are vulnerable to the same courtroom influences, though studies that compare lay laboratory responses to actual judicial sentences already incorporate these effects. Judges, moreover, appear slightly better than jurors at ignoring certain kinds of legally irrelevant considerations. ${ }^{362}$

d) From jurors to juries. Everything I've said so far pertains to the behavior of individual jurors. Even if I'm right, it is possible that juries - groups of jurors who deliberate together-

356 See Brian H. Bornstein and Sean G. McCabe, Jurors of the Absurd? The Role of Consequentiality in Jury Simulation Research, 32 Fla St U L Rev 443, 444-45 (2005).

357 See generally, for example, Nancy Mehrkens Steblay, et al, The Effects of Pretrial Publicity on Juror Verdicts: A Meta-Analytic Review, 23 L \& Hum Behav 219 (1999).

358 See Richard A. Dienstbier, et al, Effects of Weapons on Guilt Judgments and Sentencing Recommendations for Criminals, 20 Basic \& Applied Soc Psych 93 (1998).

359 See, for example, David A. Bright and Jane Goodman-Delahunty, Gruesome Evidence and Emotion: Anger, Blame, and Jury Decision-Making, 30 L \& Hum Behav 183, 200 (2006); Kevin S. Douglas, David R. Lyon, and James R. P. Ogloff, The Impact of Graphic Photographic Evidence on Mock Jurors' Decisions in a Murder Trial: Probative or Prejudicial?, 21 L \& Hum Behav 485, 497 (1997). See also generally, for example, Saul M. Kassin and David A. Garfield, Blood and Guts: General and Trial-Specific Effects of Videotaped Crime Scenes on Mock Jurors, 21 J Applied Soc Psych 1459 (1991); Jessica M. Salerno, Seeing Red: Disgust Reactions to Gruesome Photographs in Color (But Not in Black and White) Increase Convictions, 23 Psych Pub Pol \& L 336 (2017). But see Carleen M. Thompson and Susan Dennison, Graphic Evidence of Violence: The Impact on Juror Decision-Making, the Influence of Judicial Instructions and the Effect of Juror Biases, 11 Psychiatry Psych \& L 323, 334-34 (2004).

360 See Laura T. Sweeney and Craig Haney, The Influence of Race on Sentencing: A Meta-Analytic Review of Experimental Studies, 10 Behav Sci \& L 179, 191 (1992) (finding that jurors who could see rather than merely read about the defendant's race were more likely to succumb to racial bias in judging guilt).

361 Judge Bibas says "participation by victims does not lead to harsher sentences." Bibas, Machinery of Criminal Justice at 91 (cited in note 12). A great deal of research says otherwise. See, for example, Bryan Myers and Edith Greene, The Prejudicial Nature of Victim Impact Statements: Implications for Capital Sentencing Policy, 10 Psych Pub Pol \& L 492, 501-04 (2004); Bryan Myers, et al, Victim Impact Statements and Crime Heinousness: A Test of the Saturation Hypothesis, 19 Psych Crime \& L 129 (2013); Ray Paternoster and Jerome Deise, A Heavy Thumb on the Scale: The Effect of Victim Impact Evidence on Capital Decision Making, 49 Crimin 129 (2011). But see generally Theodore Eisenberg, Stephen P. Garvey, and Martin T. Wells, Victim Characteristics and Victim Impact Evidence in South Carolina Capital Cases, 88 Cornell L Rev 306 (2003).

362 See Andrew J. Wistrich, Chris Guthrie, and Jeffrey J. Rachlinski, Can Judges Ignore Inadmissible Information? The Difficulty of Deliberately Disregarding, $153 \mathrm{U} \mathrm{Pa} \mathrm{L}$ Rev 1251, 1317, 1321 (2005) (finding that judges could ignore inadmissible information obtained in violation of the right to counsel and the outcome of a search when determining whether probable cause existed). 
are more temperate than the individuals who compose them. There is certainly some research to this effect, ${ }^{363}$ and the acquittal-happy "Bronx jury" comes to mind. ${ }^{364}$ But the Bronx jury is famous because it is exceptional; there is much research that cuts the other way, including evidence of a "punitive shift" during deliberation. ${ }^{365}$ The directional effect of deliberation in any given case likely depends on jurors' predeliberation inclinations, which, I have suggested, tend to lean punitive. So predicts the phenomenon of group polarization, "by which members of a deliberating group typically end up in a more extreme position in line with their tendencies before deliberation began." 366 Significantly for the criminal sentencing context, "[g]roup polarization has been found with respect to moral outrage: When individual jurors are outraged ...., deliberation leads juries to become more outraged still." 367

Even apart from these social psychological reasons to fear that juries may be more punitive than judges, there is a crucial political economy explanation raising serious doubt that jury sentencing, in practice, will ever be the more merciful choice. The best study on actual jury sentencing outside the capital context is

363 See Iontcheva, $89 \mathrm{Va}$ L Rev at $361 \mathrm{n} 261$ (cited in note 92) (citing studies).

364 See James M. Keneally, Jury Nullification, Race, and The Wire, 55 NY L Sch L Rev 941, 946 (2010-2011) ("This term originally described a jury consisting mostly of minorities in the Bronx, New York, that refuses to convict minority defendants.").

365 See, for example, Nadine M. Connell, Death by Jury: Group Dynamics and Capital Sentencing 58-67 (LFB Scholarly 2009) (finding that juries that reported a favorable deliberation environment were more likely to return a death sentence); Virginia Criminal Sentencing Commission, 2002 Annual Report *36-38 (2002), archived at https://perma.cc/W7SD-8ZEG (finding that noncapital sentencing juries "typically handed down sentences greater than the recommendations of the sentencing guidelines," which judges frequently reduced); Mona Lynch and Craig Haney, Mapping the Racial Bias of the White Male Capital Juror: Jury Composition and the "Empathic Divide", 45 L \& Socy Rev 69, 92 (2011) (finding that deliberation created a punitive shift in mock jurors' death sentencing behavior); Mona Lynch and Craig Haney, Capital Jury Deliberation: Effects on Death Sentencing, Comprehension, and Discrimination, 33 L \& Hum Behav 481 (2009) (same).

366 Cass R. Sunstein, Infotopia: How Many Minds Produce Knowledge 92 (Oxford 2006) (emphasis omitted).

367 Id at 98. The study Sunstein cites involved jury assessments of punitive damages for corporate misconduct. See generally David Schkade, Cass R. Sunstein, and Daniel Kahneman, Deliberating About Dollars: The Severity Shift, 100 Colum L Rev 1139 (2000). The authors of that study note prior research finding that jury deliberation has a "leniency shift" on criminal guilt determinations, see id at $1140 \mathrm{n} 2$, but also predict that deliberation will increase severity in "settings in which those arguing for higher criminal punishments would have a rhetorical advantage" over those arguing for leniency, see id at 1162. 
a 2005 paper by Professor Nancy King and Rosevelt Noble. ${ }^{368}$ King and Noble use archival data from two states that authorize jury sentencing. Controlling for observable covariates of sentence severity, they find that, "for most of the offenses examined in these two states, the sentences selected by juries after jury trial were both more varied and more severe than sentences selected by judges after bench trial." ${ }^{369}$

The explanation, King and Noble contend, may have nothing to do with the backgrounds and personalities of judges and jurors. Instead, what best explains the pattern may be a straightforward "jury-sentencing penalty." In the ordinary plea bargaining context, it is well known that, because trials are resource intensive, judges impose lower sentences on defendants who plead guilty and waive their trial rights, and higher sentences on those who are convicted after trial. This is known as the "trial penalty." The same thing may happen, King and Noble conclude, for sentencing in jury sentencing states. That is, to induce defendants to waive their jury-sentencing right, judges deliberately sentence more leniently than juries do. ${ }^{370}$ Critically, the "pervasiveness of negotiated guilty pleas in criminal adjudication suggests . . . that a sentencing context lacking these forces can be created only experimentally." 371 The prospects that jury sentencing will temper the system's severity, in other words, exerting a downward pressure on incarceration rates, are dim.

\section{Bureaucratic Severity}

Alongside their faith in the basic leniency of the American laity, the democratizers espouse serious skepticism toward experts and bureaucrats. On their telling, the officials who run the criminal justice system, and the lawyers who participate in it, strive for efficiency above all else. They mass produce convictions and maximize total imprisonment years. Bureaucratic rationality, moreover, prizes formal equality over equitable considerations, inhibiting the exercise of mercy in individual cases.

368 Nancy J. King and Rosevelt L. Noble, Jury Sentencing in Noncapital Cases: Comparing Severity and Variance with Judicial Sentences in Two States, $2 \mathrm{~J}$ Empirical Legal Stud 331 (2005).

369 Id at 332.

370 See id at 358. For a similar conclusion, see Robert A. Weninger, Jury Sentencing in Noncapital Cases: A Case Study of El Paso County, Texas, 45 Wash U J Urban \& Contemp L 3, 16-17 (1994) ("Courts may [ ] reduce the price set by the jury to induce defendants to waive trial.").

371 King and Noble, 2 J Empirical Legal Stud at 361 (cited in note 368). 
This Section interrogates these arguments. I first examine two types of evidence showing how bureaucratic insulation-and its foil, electoral accountability-affect the severity of criminal justice. One compares the American system to its more bureaucratic European counterparts; the other compares elected judges and prosecutors to appointed ones. I then review suggestive evidence on the effects of repeat play among sentencing judges. Finally, I argue that penal populism shares responsibility for the decline of mercy in American criminal justice.

1. The comparative case.

A growing comparative literature investigates the determinants of penal policies. Nearly all of it suggests that populism makes criminal justice more, not less, severe. This may explain why the United States is widely regarded as having both the most punitive and the most popularly democratic criminal justice system, at least in the developed world.

Professor James Whitman frames the basic inquiry this way: "Why has American politics turned to the kind of retributivism that both French and German politics generally resists?" 372 Whitman's insight is that "retributivism . . . mobilize[s] social cohesion" in ways that are uniquely advantageous within the American political system. ${ }^{373}$ "It is surely the case," Whitman reasons, "that Americans punish more harshly because the management of the punishment system in the United States is more given over to democratic politics." ${ }^{374}$ Professor David Garland agrees, observing that "explicit attempts to express public anger and resentment have become a recurring theme of the rhetoric that accompanies penal legislation and decision-making" in the United States. ${ }^{375}$

"Conversely," says Whitman, "it is manifest that part of the reason that the retributive temper has not established itself in France and Germany is that democratic politics has much less impact on criminal justice in Europe than it does in the United States." ${ }_{766}$ In continental Western Europe, "state apparatuses remain highly autonomous, largely steered by bureaucracies that

372 James Q. Whitman, Harsh Justice: Criminal Punishment and the Widening Divide Between America and Europe 199 (Oxford 2003).

373 Id.

374 Id.

375 Garland, The Culture of Control at 9 (cited in note 39). See also id at 13-14.

376 Whitman, Harsh Justice at 199 (cited in note 372). 
are far more insulated from democratic pressures." ${ }_{377}$ "Tepid bureaucratic routinization of criminal law," the argument goes, "is an important barrier to the kind of overheated democratic retributivism that has come to America." 378 Garland, again, is in accord, crediting the rise of "professional bureaucracies" with the marginalization of "punitive sentiments," which are "replaced by more utilitarian objectives and expectations." 379 The same distinction explains how European elites abolished the death penalty notwithstanding popular support for its retention. ${ }^{380}$

Subsequent studies examining a larger number of countries, across a broader array of variables, have enriched Whitman and Garland's observations. Surveying the literature a decade ago, Professor Michael Tonry identified "risk" and "protective" factors that make it more or less likely, respectively, that a society will adopt punitive policies. ${ }^{381}$ "Prominent risk factors," Tonry explains, "include 'conflict' political systems, elected judges and prosecutors, sensationalist journalism, ... and a populist view that criminal justice policy should be strongly influenced by public sentiment and partisan politics." 382 "Prominent protective factors," in contrast, "include consensus political systems, nonpartisan judges and prosecutors, ... and a predominant view that

377 Id (emphasis omitted).

378 Id at 200. See also generally Michael Cavadino and James Dignan, Penal Systems: A Comparative Approach (Sage 2006); David Downes, Visions of Penal Control in the Netherlands, 36 Crime \& Just 93 (2007); Joachim J. Savelsberg, Knowledge, Domination, and Criminal Punishment, 99 Am J Soc 911 (1994).

379 David Garland, Punishment and Modern Society: A Study in Social Theory 183 (Chicago 1990). See also Roger Lane, Urban Police and Crime in Nineteenth-Century America, 2 Crime \& Just 1, 18 (1980) (noting "that the highly undemocratic London Metropolitan Police, founded in 1829 by the last of the pre-reformed parliaments, was much less tolerant of abusive brutality-largely directed against the 'lower orders' - than were their counterparts in democratic New York").

380 This is the basic thrust of Andrew Hammel, Ending the Death Penalty: The European Experience in Global Perspective (Palgrave Macmillan 2010). See also David Garland, Peculiar Institution: America's Death Penalty in an Age of Abolition 121-26, 162-66 (Oxford 2010); Marie Gottschalk, The Prison and the Gallows: The Politics of Mass Incarceration in America 98-101 (Cambridge 2006) (similar, for the victims' rights movement).

381 See Michael Tonry, Determinants of Penal Policies, 36 Crime \& Just 1, 13-16 (2007). See also Franklin E. Zimring and David T. Johnson, Public Opinion and the Governance of Punishment in Democratic Political Systems, 605 Annals Am Acad Pol \& Soc Sci 266, 274 (2006) (identifying "leniency" and "severity vectors").

382 Id at 6. "Conflict systems are typically characterized by two major political parties, first-past-the-post electoral systems, single-member electoral districts, and policy discontinuities." Tonry, 36 Crime \& Just at 18 (cited in note 381 ). 
criminal justice policy falls appropriately within the province of expert knowledge and professional experience."383

"Every country," Tonry explains, "experiences long-term developments . . a and moral panics associated with sensational incidents." 384 "Different mixes of risk and protective actors," in turn, explain why countries exhibit "differing degrees of [] susceptibility to overreaction" during moral panics. ${ }^{385}$ "In times of recurring moral panics about crime and drugs," Tonry emphasizes, "America's system of dispersed governmental powers, election of judges and prosecutors, and frequent legislative elections made policy makers susceptible to powerful influence by transient but widely shared public emotions." 386

Critically, not only do Tonry's risk factors describe American criminal justice to a $\mathrm{T}$, but several also reflect, in particular, the extent to which American criminal justice is already democratized. If the United States could also claim numerous protective factors, it might make sense to pursue further popular democratization if there were benefits unrelated to penal policy. But we do not have that luxury. Given all of our risk factors, and the absence of any protective counterweights, the literature Tonry marshals makes a clear prediction: further democratization will make punitive outcomes more likely and further bureaucratization, less so.

Professor Nicola Lacey arrives at similar conclusions. What makes criminal justice more moderate in continental Europe, Lacey contends, is precisely the set of political institutions that block the public's often-punitive preferences from direct implementation into public policy. ${ }^{387}$ Foremost among these may be

383 Tonry, 36 Crime \& Just at 6 (cited in note 381). See also Tapio Lappi-Seppälä, Penal Policy in Scandinavia, 36 Crime \& Just 217, 283 (2007) (observing that, in contrast to the harsher American system, "[t]he Scandinavian and continental sentencing structures are better shielded against political and populist influences"); Cheryl Marie Webster and Anthony N. Doob, Punitive Trends and Stable Imprisonment Rates in Canada, 36 Crime \& Just 297, 337-47 (2007) (citing, inter alia, appointment of judges and influence of non-elected bureaucrats to explain why the incarceration rate is lower in Canada than the United States). "Consensus systems are typically characterized by numerous political parties, proportional representation, coalition governments, and policy continuity." Id at 19. See also Holger Spamann, The U.S. Crime Puzzle: A Comparative Perspective on U.S. Crime and Punishment, 18 Am L \& Econ Rev 33, 54 (2016) (finding, through quantitative analysis, that one of the "variables that predict[s] an elevated U.S. incarceration rate" is "the absence of proportional democracy").

384 Tonry, 36 Crime \& Just at 15 (cited in note 381 ).

385 Id at 16.

386 Id at $40-41$

387 Nicola Lacey, The Prisoners' Dilemma: Political Economy and Punishment in Contemporary Democracies 63 (Cambridge 2008). 
proportional representation: "[T] he adoption and implementation of policy" in a proportional representation system must be negotiated in a more "complex bargaining process ... and will hence tend to be more insulated in their realisation from the dynamics of emotional campaigns than is typical in the majoritarian systems." 388 Lacey's prescription for nations like the United States, which lack these political features and are unlikely to acquire them, is "the re-constitution of some respect for expertise in the field" and the "removal of criminal justice policy from party political competition," where it has fared so poorly. 389 In related work, Lacey concludes that "the radically decentralised character of US democracy may have been a key, if indirect, cause of both relatively high rates of crime ... and punitiveness" in the late twentieth century. 390

One prominent comparative account does seem to cut the other way. Criminologist Vanessa Barker argues that "increased democratization can support and sustain less coercive penal regimes." ${ }^{391}$ Barker constructs her claim through case studies of California, New York, and Washington. In California, Barker says, "political actors operate . . . with a high degree of democratization but intensive social polarization." 392 In New York, by contrast, "political actors operate within a mode of elitist pragmatism." 393 And in Washington, "political actors operate within a more deliberative democracy, a mode of governance that emphasizes citizen participation, discussion, compromise, and selfgovernance." 394 Washington, it turns out, has the lowest imprisonment rate of the three. ${ }^{395}$ This is no coincidence, Barker concludes: states like Washington "have maintained relatively low imprisonment rates . . not by insulating public policy from public

388 Id at 71

389 Id at 191.

390 Nicola Lacey and David Soskice, Crime, Punishment and Segregation in the United States: The Paradox of Local Democracy, 17 Punishment \& Socy 454, 459 (2015). See also generally Nicola Lacey and David Soskice, American Exceptionalism in Crime, Punishment, and Disadvantage, in Kevin R. Reitz, ed, American Exceptionalism in Crime and Punishment 53 (Oxford 2018).

391 Barker, The Politics of Imprisonment at 12 (cited in note 139), cited in Simonson, 119 Colum L Rev at 54 (cited in note 231).

392 Barker, The Politics of Imprisonment at 10 (cited in note 139).

393 Id at 11.

394 Id.

395 Id at 8, 15. 
demands, but rather by engaging ordinary people in a more open and participatory democratic process." 396

There are several reasons to be skeptical of the inference Barker draws. First, by international standards, as Barker concedes, Washington is actually quite punitive. ${ }^{397}$ And (as Barker again concedes) Washington was hardly immune from punitive populism-Washington's voters enacted the nation's first threestrikes law in 1993, which was followed closely by a series of additional punitive policies targeting guns, drugs, and juvenile offenders. ${ }^{398}$

Second, there are countless factors other than deliberative democracy that have likely shaped Washington's penal regime. (Barker's analysis, economists would say, suffers from "omitted variable bias.") These factors fall largely into two groups: ecological and bureaucratic. As to the former, Washington is simply a different place from California and New York. Washington, for example, has the smallest black and Hispanic populations of the three states, ${ }^{399}$ the lowest rates of violent crime, ${ }^{400}$ and the lowest income inequality ${ }^{401}$-all of which predict lower incarceration rates. 402

396 Vanessa Barker, Prison and the Public Sphere: Toward a Democratic Theory of Penal Order, in David Scott, ed, Why Prison? 125, 125 (Cambridge 2013), cited in Simonson, $111 \mathrm{Nw}$ U L Rev at 1623 n 64 (cited in note 32). See also Barker, The Politics of Imprisonment at 89 (cited in note 139) (arguing that "the emergence of a more deliberative democratic process in Washington State helped defuse growing social conflict and suppress reactionary moves toward repression").

397 Barker, The Politics of Imprisonment at 88 (cited in note 139). See also Roxanne Lieb, Washington Prison Population Growth Out of Control, in Tonry and Hatlestad, eds, Sentencing Reform in Overcrowded Times 26, 26-27 (cited in note 284) (describing how Washington went from "renting excess prison beds in the late 1980s" to overcrowding in the 1990s); David Boerner, Sentencing Policy in Washington, 1992-1995, in Tonry and Hatlestad, eds, Sentencing Reform in Overcrowded Times 30, 31-35 (cited in note 284) (describing increasingly punitive measures enacted by the Washington legislature and voters in the early 1990s).

398 See Barker, The Politics of Imprisonment at 118-20 (cited in note 139).

399 US Census Bureau, American FactFinder (2010), archived at https://perma.cc/ YCA9-39XJ.

400 See Barker, The Politics of Imprisonment at 192 n 31 (cited in note 139). The "overall crime rate in Washington," however, "has hovered well above the national average for over thirty years, at times higher than that in California or New York." Id at 16.

401 New York is actually first in income inequality and California is fourth. Washington is thirty-second. See Emmie Martin, US States with the Highest Levels of Income Inequality (CNBC, Mar 12, 2018), archived at https://perma.cc/5ZAU-T4C9.

402 On race and ethnicity, see David F. Greenberg and Valerie West, State Prison Populations and Their Growth, 1971-1991, 39 Crimin 615, 633, 638 (2001); Xia Wang and Daniel P. Mears, Sentencing and State-Level Racial and Ethnic Contexts, 49 L \& Socy Rev 883, 899, 905-06 (2015). On crime rates, see Enns, Incarceration Nation at 141-42 (cited 
As for bureaucratic factors, Washington touts some of the nation's most impressive expert-driven criminal justice institutions, which have exerted a moderating force. The Washington State Institute for Public Policy, a nonpartisan public research group founded in 1983, conducts rigorous criminal justice research, often exposing the enormous costs (and more questionable benefits) of punitive penal programs. ${ }^{403}$ And according to Professor Rachel Barkow's analysis, the Washington Sentencing Commission has also played a "pivotal role" in promoting decarceral reforms by "provid[ing] the legislature with cost projections" for different policy alternatives. ${ }^{404}$

Of course, Barker might argue that Washington's unique democratic process is responsible for these progressive institutions. But that argument suffers the same omitted variable bias as the principal one. ${ }^{405}$ So, too, does Barker's argument that what really matters is not the punitive laws Washingtonians enacted in the early 1990s, but how the effects of those laws were dampened relative to those of similar laws in California. ${ }^{406}$ In each case, the ecological differences among the states are just as plausible

in note 276); Greenberg and West, 39 Crimin at 638 (cited in note 402). On economic inequality, see David Jacobs and Ronald E. Helms, Toward a Political Model of Incarceration: A Time-Series Examination of Multiple Explanations for Prison Admission Rates, $102 \mathrm{Am}$ J Soc 323, 349 (1996). See also Jacobs and Carmichael, 67 Am Sociological Rev at 128 (cited in note 304) (finding that states with higher income inequality are more likely to retain the death penalty). Barker acknowledges the potential influence of crime rates and race but more or less brushes it aside. See Barker, The Politics of Imprisonment at 16-19 (cited in note 139).

403 See, for example, Roxanne Lieb, Hal Scogin, and Gregory Weeks, Washington State Sex Offenders: Costs of Sentencing Options *1 (Washington State Institute for Public Policy, 1993), archived at https://perma.cc/5E98-LYUQ (reporting that a "typical sex offender who is incarcerated costs state and local governments five times more than an offender who successfully completes an alternative sentence").

404 Rachel E. Barkow, Administering Crime, 52 UCLA L Rev 715, 781 (2005).

405 For example, Barker explains how, starting in the 1960s, Washington embraced the "principle of parsimony"-a preference for the least restrictive sanction possiblewhich informed the state's first sentencing guidelines in 1983. Barker, The Politics of Imprisonment at 86-87 (cited in note 139). She does not, however, clearly explain why Washington chose parsimony in the first place. There is some suggestion, actually, that elites led the way. See id at 101 ("In Washington, political leaders, civic leaders, and criminal justice officials rejected more conservative characterizations of crime and rejected a quick turn to more coercive forms of crime control.”); id at 103-04 (describing how, in 1978, a statistical researcher authored a set of proposals to regulate the prison population, which "eventually became institutionalized in the state's penal policies").

406 See id at $120-22$. 
an explanation as Washington's deliberative democratic structures-or more so. 407

Tellingly, Barker herself recognizes the advantages of New York's "pragmatic but elitist mode of governance" that "relies heavily on expert knowledge and scientific inquiry." ${ }_{408}$ "By developing a rather calculated approach to penal sanctioning," explains Barker, New York officials "depressed the raw emotion embedded in retribution and undermined the morality of transformation linked to penal welfarism." ${ }^{409}$ Barker contrasts New York's approach with California's highly democratized, "neopopulist" process. "Initially created to undercut corrupt politicians and express distrust of state elites," Barker writes, California's oftused "initiative process has also been used to legislate intolerance toward minority racial and ethnic groups since its inception." 410 And New York's punishment rate (322 per 100,000), it turns out, is closer to Washington's (273) than California's (471). ${ }^{411}$

\section{Electoral incentives.}

A curious omission from the democratization agenda is any discussion of judicial and prosecutorial elections. There is the passing suggestion that insulated officials are worse than electorally accountable ones, ${ }^{412}$ but, for the most part, the literature is silent on the issue. One would think the democratizers would be eager to abolish executive appointments in favor of elections. Indeed, the national shift from appointed to elected state-court judges occurred during another period of "democratization of American government": the Jacksonian era.413 Lay participation may be the democratizers' ultimate prize, but voting certainly counts for something-it's a step away from bureaucracy and

407 See Lisa L. Miller, Book Review, The Politics of Imprisonment: How the Democratic Process Shapes the Way America Punishes Offenders, 21 L \& Pol Book Rev 146, 149 (2011), which reviews demographic changes in California and Washington and posits that

Barker's account of a more deliberative and rational response to crime changes in Washington may be partly, if not largely, attributable to the fact that far fewer white Washingtonians considered crime to be essentially a problem of blacks and felt far less threatened by large populations of blacks entering the state's cities.

408 Barker, The Politics of Imprisonment at 45 (cited in note 139).

409 Id at 126.

410 Id at 43.

411 Id at 15 .

412 See Bibas, Machinery of Criminal Justice at xxi (cited in note 12).

413 See Walker, Popular Justice at 72 (cited in note 172). 
toward the participatory ideal. In fact, at times, the democratizers seem to view voting as the bedrock form of participatory democracy. ${ }^{414}$

The problem for the democratizers, as they surely know, is that judicial and prosecutorial electoral incentives lead to harsher outcomes. A "law and order" campaign is a strong one; "soft on crime" is weak. A strong body of rigorous empirical evidence finds that electoral incentives push both judges ${ }^{415}$ and prosecutors ${ }^{416}$ in a punitive direction.

The democratizers might respond to this evidence, first, by suggesting that elected "law and order" judges-just like threestrikes laws, perhaps_-don't truly reflect voters' preferences. Yet

414 Kleinfeld, $111 \mathrm{Nw}$ U L Rev at 1394 (cited in note 14).

415 See Daniel R. Pinello, The Impact of Judicial-Selection Method on State-SupremeCourt Policy: Innovation, Reaction, and Atrophy 99 (Greenwood 1995) (summarizing a finding, based on matched pairs of state supreme courts, that courts with gubernatorially appointed judges adopt defendant-friendly rules more often than courts with popularly elected judges); David Abrams, et al, Judicial Delegation (working paper, June 29, 2018), archived at https://perma.cc/RW64-MDMG (finding that judges who cycle through districts are more punitive in their electoral districts shortly before elections); Carlos Berdejó and Noam Yuchtman, Crime, Punishment, and Politics: An Analysis of Political Cycles in Criminal Sentencing, 95 Rev Econ \& Stats 741, 741-42 (2013) (finding that sentences are 10 percent longer at the end of a judge's political cycle and upward departures increase across the cycle); John Blume and Theodore Eisenberg, Judicial Politics, Death Penalty Appeals, and Case Selection: An Empirical Study, 72 S Cal L Rev 465, 470-75 (1999) (finding that judges facing retention elections act less favorably toward capital defendants on appeal); Paul Brace and Brent D. Boyea, State Public Opinion, the Death Penalty, and the Practice of Electing Judges, 52 Am J Pol Sci 360 (2008) (finding that public support for the death penalty makes elected, but not non-elected, judges more punitive); Sanford C. Gordon and Gregory A. Huber, The Effect of Electoral Competitiveness on Incumbent Behavior, 2 Q J Pol Sci 107 (2007) (finding that judges running in partisan contests are more punitive than those running in unopposed retention elections); Gregory A. Huber and Sanford C. Gordon, Accountability and Coercion: Is Justice Blind When It Runs for Office?, 48 Am J Pol Sci 247 (2004) (finding that elected trial judges become more punitive in sentencing as elections near); David Jacobs and Aubrey L. Jackson, On the Politics of Imprisonments: A Review of Systematic Findings, 6 Ann Rev L \& Soc Sci 129, 138 (2010) (finding, based on prior studies, "strong reasons to believe that political factors help determine sentencing" in the expected direction); Kyung H. Park, The Impact of Judicial Elections in the Sentencing of Black Crime, $52 \mathrm{~J}$ Hum Res 998 (2017) (finding that incarceration rates for black, but not white, defendants rise at the end of the election cycle).

416 See Siddhartha Bandyopadhyay and Bryan C. McCannon, The Effects of the Election of Prosecutors on Criminal Trials, 161 Pub Choice 141, 152 (2014) (finding that in election years the number of cases brought to trial by prosecutors' offices increased by as much as 24 percent); Andrew Dyke, Electoral Cycles in the Administration of Criminal Justice, 133 Pub Choice 417, 435-36 (2007) (finding that, in election years, defendants are convicted at higher rates and are less likely to have all charges dropped); Bryan C. McCannon, Prosecutor Elections, Mistakes, and Appeals, $10 \mathrm{~J}$ Empirical Legal Stud 696, 710-11 (2013) (finding that the popular election of prosecutors results in inaccurate sentences and wrongful convictions). 
most of the evidence suggests that they do.417 Second, and relatedly, it is possible that, with better information, voters would choose more lenient judges. But "well-informed voters" are an elusive group. ${ }^{418}$ And the prospects for improvement along this dimension seem exceedingly small. ${ }^{419}$ Finally, the democratizers might point to the recent election of "progressive prosecutors" in several major cities. ${ }^{420}$ This is, to my mind, a welcome but ultimately modest development. Progressive prosecutors make up around 1 percent of district attorneys today, ${ }^{421}$ and it is far from clear how far this trend will spread. ${ }^{422}$ We are slowly learning, moreover, about the difficulties these officials are facing in implementing their campaign promises. ${ }^{423}$ In short, reform-minded prosecutors may be preferable to the prosecutors who got us to where we are today, but a system of appointed prosecutors may well be better still.

3. Repeat play.

An additional factor distinguishes criminal justice bureaucrats-and judges in particular-from lay participants like ju-

417 See Claire S.H. Lim, Preferences and Incentives of Appointed and Elected Public Officials: Evidence from State Trial Court Judges, 103 Am Econ Rev 1360, 1392-93 (2013) (finding that the sentencing harshness of elected judges correlates strongly to the political ideology of voters, while that of appointed judges does not); Joanna M. Shepherd, The Influence of Retention Politics on Judges' Voting, 38 J Legal Stud 169, 171 (2009) (finding that elected judges' voting is strongly associated with retention politics). But see Stephen J. Choi, G. Mitu Gulati, and Eric A. Posner, Professionals or Politicians: The Uncertain Empirical Case for an Elected Rather than Appointed Judiciary, $26 \mathrm{~J}$ L Econ \& Org 290, 328 (2010) (finding that elected judges are not less independent than appointed ones).

418 See generally Arthur Lupia, Uninformed: Why People Know So Little About Politics and What We Can Do About It (Oxford 2016). See also Jeff Manza and Christopher Uggen, Locked Out: Felon Disenfranchisement and American Democracy 115-16 (Oxford 2008).

419 Angus Campbell, et al, The American Voter 544 (Chicago 1960). See also Bryan Caplan, The Myth of the Rational Voter: When Democracies Choose Bad Policies 3 (Princeton 2007).

420 See Lauren M. Ouziel, Democracy, Bureaucracy and Criminal Justice Reform, 61 BC L Rev *1 (forthcoming 2020), archived at https://perma.cc/3VB3-K4DS. See also Pfaff, Locked In at 162 (cited in note 303).

421 See Ben Austen, On the Inside, NY Times Mag 44 (Nov 4, 2018) (reporting that "voters have elected 30 reform-minded prosecutors" out of 2,300 positions).

422 See Wright, Elected Prosecutors and Police Accountability at 241-49 (cited in note 79) (providing data showing that prosecutorial elections "produce low turnover and few challenges" and expressing skepticism that recent elections portend a significantly broader trend). See also Pfaff, Locked In at 162 (cited in note 303) (observing that "[r]eforms at one level can be thwarted by parties at other levels").

423 See, for example, Ouziel, 61 BC L Rev at *35-38 (cited in note 420) (describing line attorneys' motivations to resist reform); Austen, On the Inside (cited in note 421) (similar). 
rors: judges are repeat players and jurors are not. The democratizers say the distinction favors jurors-recall the "jaded" and punitive bureaucrats Judge Bibas describes. ${ }^{424}$ Their argument is not implausible, but the evidence for it is thin. A recent empirical study suggests, in fact, that the opposite effect may prevail. ${ }^{425}$

Professor Adi Leibovitch compares the sentencing practices of judges who, by chance, presided over criminal caseloads of differing average severities upon initially taking the bench. ${ }^{426}$ She finds that, going forward, the judges initially exposed to more severe cases sentence more leniently than those initially exposed to less severe cases. ${ }^{427}$ "Legal judgments are affected by the relative comparison of a particular case with the other cases in the caseload before the judge," Leibovitch concludes. ${ }^{428}$ Transposed into the judge-juror context, Leibovitch's evidence suggests that judges' exposure to a steady flow of criminal cases may well inure them to the "shock value" most jurors will experience upon learning the details of a serious crime, leading the judges to view cases as relatively less severe than jurors. To be clear, Leibovitch does not directly compare judges and jurors, but her evidence does point in this direction.

\section{Mercy.}

There is likely truth to the democratizers' argument that the "administrative ideal of equality across cases" has tended to inhibit the discretion necessary to dispense mercy in individual cases. ${ }^{429}$ After all, "[i]n criminal justice as elsewhere, discretion and discrimination travel together." 430 There is no question, for example, that progressive reformers concerned about official discrimination supported determinate sentencing laws and the restriction of parole. ${ }^{431}$ To be clear, the democratizers make no persuasive argument that these antidiscrimination reforms were not

\footnotetext{
424 See notes 140-42 and accompanying text.

425 Judge Bibas acknowledges this alternative possibility-that judges grow "mellower" over time-though it is unclear from context what normative valence he attaches to it. See Bibas, Machinery of Criminal Justice at 32 (cited in note 12).

426 See Adi Leibovitch, Relative Judgments, 45 J Legal Stud 281, 293-95 (2016).

427 See id at 303-09.

428 Id at 320 .

429 Bibas, Machinery of Criminal Justice at 24 (cited in note 12).

430 William J. Stuntz, The Political Constitution of Criminal Justice, 119 Harv L Rev 781,822 (2006).

431 See Walker, Popular Justice at 217-21 (cited in note 172).
} 
worth their costs, nor do they suggest how to balance the values of mercy and equal treatment.

In any event, the democratizers offer a remarkably one-sided historical account that minimizes the role that populist forces, too, have played in closing doors to mercy. Indeterminate sentencing and parole, in particular, are critically expert-driven mechanisms for the dispensation of mercy. The movements to rein them in were fueled by the same distrust of experts and elites that the democratizers espouse today, boosted by harsh popular views.

Examples are legion. In the run-up to the enactment of the federal sentencing guidelines, "judges came under attack as too prone to individualize justice to suit the particular circumstances of defendants in ways that limited punishment and diminished deterrence." 432 "The history of the adoption of the guidelines," Professor Jonathan Simon observes, "suggests a quite deliberate intent to reject judicial governance as such." 433 Similarly, in 1994, when California voters passed the state's three-strikes law by a three-to-one margin, trust in government was low. "[C]itizens worr[ied] that judges will identify with offenders and treat them with inappropriate leniency." ${ }_{434}$ "A bad judge in this view," in other words, "is one prone to coddle criminals and thus act against the interests of the citizenry, and mandatory punishment is the way to ensure against such weakness.” ${ }^{435}$

Garland argues more generally that the "politicization of crime control" led to "a sharp reversal of the historical process whereby the power to punish was largely delegated to professional experts and administrators." 436 "One sees this reverse transfer of power," Garland observes, "in a series of measures (fixed sentence law reforms, mandatory sentences, national standards, truth in sentencing, restrictions on early release, etc.) that have shifted detailed decision-making tasks back to the centre." ${ }_{437}$ Likewise, Professor Sklansky agrees with those who "link the recent popularity of mandatory sentences and 'zero-tolerance' policies to disenchantment with the kind of 'individualized justice' previously dispensed by 'expert judges, and supported by a

432 Jonathan Simon, Governing Through Crime: How the War on Crime Transformed American Democracy and Created a Culture of Fear 127 (Oxford 2007).

433 Id at 128.

434 Zimring, Hawkins, and Kamin, Punishment and Democracy at 231 (cited in note 40). 435 Id.

436 Garland, The Culture of Control at 13 (cited in note 39).

437 Id. 
panoply of normalizing professionals (psychologists, social workers, probation officers, and so on)." 438 The point is simply that it's unfair, and misleading, to count the demise of mercy as a demerit against bureaucracy alone when populism shares the blame.

\section{Equality}

One of the animating ideas behind democratization, following Stuntz, is that local democratic rule-that is, neighborhood control-will moderate punishment because the same people doling out sanctions will bear them. For similar reasons, the risk of biased punishment is also reduced. This is how it worked in the Gilded Age, Stuntz contends, when-outside the South-the criminal justice system was surprisingly egalitarian. This Section scrutinizes this important claim in the light of pertinent social scientific evidence.

Two preliminary points are in order. First, unless it eradicates all racial inequality in the criminal justice system, if democratization increases the severity of criminal punishment, it will disparately impact black men. Severity and equality considerations are tightly intertwined. Second, and relatedly, Stuntz's argument, in the abstract, sounds in severity as well as equality. It would seem to apply, for example, even in a racially homogeneous society. In practice, however, the argument is advanced most forcefully as a mechanism to alleviate racial inequality. Rather than let white suburbanites govern black urban defendants, the thinking goes, let black urban communities govern themselves. This will naturally moderate punishment and reduce the effects of any racial bias the white suburbanites might harbor. I respond to the argument in this register.

To begin, a few observations about Stuntz's touchstone, the Gilded Age North. I discussed above how Gilded Age communities were not as inclusive or tight-knit, and justice not as functional, as Stuntz makes it sound. But even granting Stuntz egalitarian justice in Northern cities during the Gilded Age, the nation has

438 Sklansky, Democracy and the Police at 92 (cited in note 13), quoting Jonathan Simon, Crime, Community, and Criminal Justice, 90 Cal L Rev 1415, 1418 (2002). See also Paula M. Ditton and Doris James Wilson, Truth in Sentencing in State Prisons *2 (US Department of Justice, Jan 1999), archived at https://perma.cc/JNZ3-RP5K ("Over the last two decades, sentencing requirements and release policies have become more restrictive, primarily in response to widespread 'get tough on crime' attitudes in the Nation."); Roberts, et al, Penal Populism and Popular Opinion at 9 (cited in note 40) (attributing mandatory sentencing and the restriction of judicial discretion to "penal populism"). 
evolved in ways that inhibit the system's capacity to distribute punishment equally through mechanisms of local democracy. Crime is up, especially in urban centers. Urban populations are more mobile. Major cities have deindustrialized. Most important for present purposes, the Great Migration drastically changed racial demographics across the region. The Gilded Age North that Stuntz describes was largely white. Not so today. "In 1910," Stuntz reports, "blacks made up 6 percent of Philadelphia's population, 2 percent of Chicago's and Cleveland's, and a mere 1 percent of Detroit's." 439 By 1980, "those percentages were 38 percent, 40 percent, 44 percent, and 63 percent, respectively." ${ }^{440}$ Stuntz contends that egalitarian justice among whites in the Gilded Age "spilled over" onto the small number of Northern blacks. ${ }^{441}$ Even assuming this is true, there is little reason to think, without more evidence, that a similar dynamic would hold today. Indeed, the failure of white egalitarian justice to "spill over" onto blacks is one of the principal reasons reformers bureaucratized the system in the first place. ${ }^{442}$

It is helpful, in thinking through these issues, to situate them in two distinct, if highly stylized, demographic settings: first, majority-black neighborhoods, and second, racially heterogeneous neighborhoods in which blacks are a discrete minority.

\section{1. "Black neighborhoods."}

Take first the stronger case for the democratizers: predominantly black neighborhoods in urban settings. To replace the dynamic Stuntz describes well-in which prosecutors and judges answerable to (whiter) countywide electorates prosecute and sentence black defendants, and (whiter) juries selected from the county determine their guilt - the democratizers envision neighborhood control. Police drawn from, and accountable to, the neighborhood would decide whom to arrest and refer to neighborhood prosecutors; neighborhood juries would check the state at

439 Stuntz, Collapse of American Criminal Justice at 16 (cited in note 15).

440 Id.

441 Stuntz, 121 Harv L Rev at 2003 (cited in note 148).

442 See Samuel Walker, Origins of the Contemporary Criminal Justice Paradigm: The American Bar Foundation Survey, 1953-1969, 9 Just Q 47, 57-59 (1992). See also Michael J. Klarman, The Racial Origins of Modern Criminal Procedure, 99 Mich L Rev 48, 93-94 (2000) (describing the roots of modern US Supreme Court criminal procedure doctrine in concerns about mistreatment of black defendants in the South). 
multiple junctures from bail through sentencing. Black defendants would be punished by their own, rather than by detached and unsympathetic whites. Familiarity would temper severity.

Maybe, but not necessarily. The problem is that the "neighborhood effect" pushes in both directions simultaneously. Black voters and jurors may be more sympathetic than whites to black defendants from their neighborhood, to be sure. But they may be more fearful of those same defendants too. For suburban whites, crime is an abstraction; for blacks in some urban neighborhoods, it's reality. Blacks are far more likely than whites to be victims of crime, including violent crime. ${ }^{443}$ Unsurprisingly, research suggests that blacks are, on average, more fearful of crime than whites are, ${ }^{444}$ and that blacks for whom crime is more salient are more supportive of punitive measures that disproportionately burden black offenders. ${ }^{445}$ The democratizers sometimes acknowledge these competing forces but never wrestle them to the ground. Nor do they present a compelling case that the forces of leniency will win out. Indeed, a good deal of evidence suggests that any such assumption is too facile. ${ }^{446}$

Consider Professor James Forman Jr's now-famous account of popular support for "tough on crime" policies in majority-black Washington, DC. Forman surveys black opposition to marijuana decriminalization and support for stricter gun laws and punitive

443 See Ghandnoosh, Race and Punishment at *10-11 (cited in note 6) (marshaling statistics).

444 See id at *11-12. See also Wesley G. Skogan, Crime and the Racial Fears of White Americans, 539 Annals Am Acad Polit \& Soc Sci 59, 62 (1995).

445 See Bobo and Johnson, 1 Du Bois Rev at 167-68 (cited in note 289); Steven F. Cohn, Steven E. Barkan, and William A. Halteman, Punitive Attitudes Toward Criminals: Racial Consensus or Racial Conflict?, 38 Soc Probs 287, 293 (1991) (finding that fear of crime predicts punitive attitudes in blacks but not whites). See also Robert J. Sampson and Dawn Jeglum Bartusch, Legal Cynicism and (Subcultural?) Tolerance of Deviance: The Neighborhood Context of Racial Differences, 32 L \& Socy Rev 777, 777 (1998) ("Contrary to received wisdom, we find that African Americans and Latinos are less tolerant of deviance-including violence-than whites.”). Almost twice as many blacks as whites identified "crime, violence, and drugs" as the nation's top problem in 2001. Lawrence D. Bobo and Victor Thompson, Unfair by Design: The War on Drugs, Race, and the Legitimacy of the Criminal Justice System, 73 Soc Rsrch 445, 455-56 (2006).

446 When presented with general survey questions, black respondents do express less support than whites for various punitive policies, though the majority of both whites and blacks support many punitive measures. See Ghandnoosh, Race and Punishment at *8-9 (cited in note 6) (reviewing studies). Racial differences are "eclipsed by variation along other demographic lines, including class and education level." James Forman Jr, Racial Critiques of Mass Incarceration: Beyond the New Jim Crow, 87 NYU L Rev 21, 37 n 51 (2012) (citing sources). 
sentences in the 1970s and 1980s, ${ }^{447}$ both driven by an "overriding concern to protect black lives from the scourge of drugs and violence decimating their communities." 448 In 1986, DC launched Operation Clean Sweep, a "military-inspired" police antidrug initiative featuring battle-ready weaponry and aggressive new tactics. ${ }^{449}$ A decade later, then-US Attorney for the District of Columbia Eric Holder pioneered an operation of his own, Operation Ceasefire, which blessed pretextual traffic stops as a tool to get guns "out of the hands of young black men." 450

Vanessa Barker and political scientist Michael Javen Fortner tell similar stories about support for the harsh Rockefeller drug laws among black New Yorkers. ${ }^{451}$ "Since the late 1960s," Barker writes, "many black activists have pushed [New York] to take a tougher stand against lawlessness in their communities." 452 The major black newspaper in New York City advocated "mandatory life sentences for the "non-addict drug pusher of hard drugs," for example, and "the NAACP's Citizens Mobilization Against Crime supported tougher penalties, proposing "lengthening minimum prison terms for muggers, pushers, 1st degree murders." "453 Black support for punitive policies was not merely a localized phenomenon, however. Professor Randall Kennedy documents support by a majority of black members of Congress - those who, in his words, "concerned themselves most intently and consistently with elevating the fortunes of African-Americans"-for the federal Anti-Drug Abuse Act of 1986, ${ }^{454}$ which created the now-notorious

47 See Forman, Locking Up Our Own at 17-77 (cited in note 318).

448 Devon W. Carbado and L. Song Richardson, Book Review, The Black Police: Policing Our Own, 131 Harv L Rev 1979, 1984 (2018).

449 See Forman, Locking Up Our Own at 167-68 (cited in note 318). See also id at 164-66 (describing similar initiatives encouraged by black leaders in other cities); Randall Kennedy, The State, Criminal Law, and Racial Discrimination: A Comment, 107 Harv L Rev 1255, 1259 n 16 (1994) ("[B]lacks had also called for extraordinary interventions on the part of law enforcement authorities, ranging from imposition of martial law to summary execution of drug dealers.").

450 Carbado and Richardson, Book Review, 131 Harv L Rev at 1988 (cited in note 448). See Forman, Locking Up Our Own at 194-211 (cited in note 318).

451 See Barker, The Politics of Imprisonment at 149-52 (cited in note 139); Michael Javen Fortner, Black Silent Majority: The Rockefeller Drug Laws and the Politics of Punishment (Harvard 2015).

452 Barker, The Politics of Imprisonment at 150 (cited in note 139).

453 Id at 151, quoting Rockefeller and Narcotics, Amsterdam News A4 (Jan 13, 1973).

454 Pub L No 99-570, 100 Stat 3207, codified as amended in various sections of Title 21. 
(and defunct) 100-to-1 crack-power cocaine sentencing differential.455 Similarly, during his 1988 presidential campaign, Jesse Jackson castigated Ronald Reagan for his weakness in the War on Drugs. ${ }^{456}$

In a lesser-known account, historian Fritz Umbach unearths the fascinating story of the New York City Housing Authority Police Department, which exclusively patrolled the city's public housing projects as part of "America's longest experiment in community policing." "457 "From the late 1950s until the end of the 1970s," Umbach explains, "tenants' most urgent and insistent political goal was always the hiring of more housing police," ${ }^{458}$ which took precedence over even community programs. ${ }^{459}$ Prominent tenant groups implored authorities to enforce housing rules and evict troublemakers, bemoaning a 1971 consent decree that made eviction more difficult. ${ }^{460}$ In fact, tenants played a key role in undermining the decree, pushing a reluctant US Attorney for the Southern District of New York, Rudolph Giuliani, to use federal civil asset forfeiture laws to evict individuals who were dealing drugs, a practice for which Giuliani would later take credit as it spread nationwide. ${ }^{461}$

Finally, a recent empirical study attempts to quantify, on a national scale, some of the phenomena that Forman and others discuss. Using nationally representative survey data spanning 1955 to 2014, the authors find that "black and not just white Americans became more punitive" during this period and that black respondents exhibited "relatively high levels of punitiveness" alongside "persistent anxiety about crime." 462 They further report, based on an analysis of voting patterns in the US House of Representatives between 1968 and 2015, that "an absolute majority of African-American legislators voted in favor of each of the

455 See Randall Kennedy, Race, Crime, and the Law 370 (Pantheon 1997); id at 37076. Thirteen of twenty voting members of the Congressional Black Caucus voted for the law. Naomi Murakawa, The First Civil Right: How Liberals Built Prison America 124 (Oxford 2014).

456 See Murakawa, The First Civil Right at 118 (cited in note 455).

457 Fritz Umbach, The Last Neighborhood Cops: The Rise and Fall of Community Policing in New York Public Housing 3 (Rutgers 2011).

458 Id at 71. See also Miller, The Perils of Federalism at 162 (cited in note 139) (reporting that citizen groups in Pittsburgh frequently demanded more police).

459 See Umbach, The Last Neighborhood Cops at 100 (cited in note 457).

460 See id at $64-65,114$.

461 See id at $121,149-58$

462 Clegg and Usmani, The Racial Politics of the Punitive Turn *21, 22 (cited in note 303$)$. 
major federal crime bills" and "consistently supported bills that increased mandatory minimums," and that, "amid rising crime in the 1980 s and $1990 \mathrm{~s}$, there was a discernible rise in average support for punitive bills" among black congressmen. ${ }^{463}$ Perhaps most surprisingly, the authors find that increased black political representation in state and federal legislatures had a punitive impact on state-level imprisonment and policing rates. ${ }^{464}$

All of these accounts are subtle, complex, and contestable. ${ }^{465}$ Obviously not all members of the relevant constituencies shared these punitive views. (Recall, again, the Bronx jury.) And those who did operated under structural constraints that limited options for treating community ills. "In the era of mass incarceration," observes Professor Michelle Alexander, "poor African Americans are not given the option of great schools, community investment, and job training. Instead, they are offered police and prisons. If the only choice that is offered blacks is rampant crime or more prisons, the predictable (and understandable) answer will be "more prisons."' 466

Still, these stories all suggest that it is too simplistic to assume that "black communities" will reflexively push toward greater leniency in criminal justice, especially when the same basic structural constraints still exist. The argument is not that blacks inherently desire punitive policies, which might, under some theories, justify those policies. The argument is simply that, under existing structural constraints, one should not too quickly predict that, if given greater control over criminal justice policy, black Americans will necessarily temper it. 467

463 Id at *24, 25 .

464 See id at *25-26.

465 See, for example, Michelle Alexander, The New Jim Crow: Mass Incarceration in the Age of Colorblindness 208-17 (New Press 2012). Fortner's work has received some of the strongest criticism. See, for example, Khalil Gibran Muhammad, Book Review, 'Black Silent Majority,' by Michael Javen Fortner (NY Times, Sept 21, 2015), archived at https://perma.cc/7LFB-ALP4; Donna Murch, Who's to Blame for Mass Incarceration? (Boston Rev, Oct 16, 2015), archived at https://perma.cc/4KHB-8HSL.

466 Alexander, The New Jim Crow at 210 (cited in note 465). See also Lisa L. Miller, The Myth of Mob Rule: Violent Crime and Democratic Politics 197-98 (Oxford 2016). The authors themselves generally acknowledge these constraints. See, for example, Forman, Locking Up Our Own at 11-13 (cited in note 318); Fortner, Black Silent Majority at 17 (cited in note 451); Clegg and Usmani, The Racial Politics of the Punitive Turn at *31-36 (cited in note 303 ).

467 This is one lesson of Professor Lisa Miller's work on the ways that federalism "divides democratic participation and state accountability in ways that strengthen existing power differentials and disadvantage those groups already marginalized in the political process." Miller, The Perils of Federalism at 27 (cited in note 139). See also Miller, The 
To be clear, it is entirely possible that "some level of punitiveness among blacks could result from-rather than disprove-the existence of racism." ${ }^{668}$ Steeped in the same cultural influences as non-blacks, and naturally inclined (as we all are) to legitimate existing social hierarchies, many black Americans, research reports, develop "out-group preferences." ${ }^{469}$ For example, black Americans, like whites, associate blackness with aggression and criminality. ${ }^{470}$ In recent surveys, "blacks were more likely to believe that the communities they lived in lacked moral values" 471 and four-fifths of black youth agreed that "too many young black Americans had the wrong morals about important things like work and sex." ${ }^{772}$ Black Americans also divide along characteristics such as age, class, or skin color, engaging in what political scientist Cathy Cohen describes as "secondary marginalization of those who are most vulnerable in oppressed communities." 473

Separate from its likely effects on policy-level decisions, this complex psychology follows individuals into the jury box. And research suggests that, when juries are fairly homogeneous-as the democratizers imagine neighborhood juries in black neighborhoods will be-group deliberation can amplify, rather than moderate,

Myth of Mob Rule at 200 (cited in note 466) (concluding that American government may be "not particularly capable of enacting and implementing comprehensive policies that would reduce crime through other means" than punishment).

468 Darren Lenard Hutchinson, Book Review, Who Locked Us Up? Examining the Social Meaning of Black Punitiveness, 127 Yale L J 2388, 2413 (2018).

469 See id at 2413-17 (reviewing research). See also Nilanjana Dasgupta, Implicit Ingroup Favoritism, Outgroup Favoritism, and Their Behavioral Manifestations, 17 Soc Just Rsrch 143, 148-49 (2004) (discussing system justification theory); John T. Jost, Brett W. Pelham, and Mauricio R. Carvallo, Non-Conscious Forms of System Justification: Implicit and Behavioral Preferences for Higher Status Groups, 38 J Experimental Soc Psych 586, 587-89 (2002).

470 See, for example, Heather M. Kleider, Sarah E. Cavrak, and Leslie R. Knuycky, Looking Like a Criminal: Stereotypical Black Facial Features Promote Face Source Memory Error, 40 Memory \& Cognition 1200, 1204 (2012); H. Andrew Sagar and Janet Ward Schofield, Racial and Behavioral Cues in Black and White Children's Perceptions of Ambiguously Aggressive Acts, 39 J Personality \& Soc Psych 590, 596 (1980).

471 Fredrick C. Harris, The Price of the Ticket: Barack Obama and the Rise and Decline of Black Politics 134-35 (Oxford 2012).

472 Cohen, Democracy Remixed at 49 (cited in note 211).

473 Id at 28. See Fortner, Black Silent Majority at 14 (cited in note 451) ("Within urban communities across the United States, working- and middle-class African Americans differentiate between 'us' and 'them,' between 'decent families' and 'street families.' And 'decent families' do not believe that their fate is linked with the fate of 'street families."'); Jennifer L. Hochschild and Vesla Weaver, The Skin Color Paradox and the American Racial Order, 86 Soc Forces 643, 644 (2007) ("Dark-skin discrimination occurs within as well as across races.") (citation omitted). 
individual biases. ${ }^{474}$ Importantly, this can include a so-called black sheep effect, which manifests in severity toward one's ingroup. This effect is especially likely, research shows, when evidence of guilt is strong, as jurors psychologically distance themselves from the defendant and treat him harshly. ${ }^{475}$

Likewise, we should not expect that hiring more black police officers-"recruiting officers with roots in or links to the communities they police," 476 in the democratizers' parlance-will drastically change the nature of urban policing. Professors Devon Carbado and Song Richardson make this point forcefully in their review of Forman's book. 477 The "very factors . . . that explain why white police officers might systematically over-police and deploy violence against African Americans," they show-including Fourth Amendment law, institutional incentives, and cognitive biases-"arguably implicate black police officers as well." 478 Black test subjects, for example-including black police officers-exhibit "shooter bias" just as whites do, mistakenly "shooting" unarmed blacks more often than unarmed whites. ${ }^{479}$ And "the pressures black police officers likely experience to fit into their departments potentially compound the problem.” ${ }^{880}$ To become part of the community of "blue," that is, "black police officers may

474 See, for example, Sunstein, Infotopia at 78-81 (cited in note 366); Norbert L. Kerr, Keith E. Niedermeier, and Martin F. Kaplan, Bias in Jurors vs Bias in Juries: New Evidence from the SDS Perspective, 80 Org Behav \& Hum Decision Processes 70 (1999); Geoffrey P. Kramer, Norbert L. Kerr, and John S. Carroll, Pretrial Publicity, Judicial Remedies, and Jury Bias, 14 L \& Hum Behav 409 (1990); Lynch and Haney, Capital Jury Deliberation at 491 (cited in note 365); Robert J. MacCoun, Experimental Research on Jury Decision-Making, 244 Science 1046, 1048 (1989); David G. Myers and George D. Bishop, Discussion Effects on Racial Attitudes, 169 Science 778 (1970).

475 See, for example, Derek Chadee, Race, Trial Evidence and Jury Decision Making, 1 Caribbean J Crimin \& Soc Psych 59, 75 (1996); José M. Marques, The Black-Sheep Effect: Out-Group Homogeneity in Social Comparison Settings, in Dominic Abrams and Michael A. Hogg, eds, Social Identity Theory: Constructive and Critical Advances 131 (SpringerVerlag 1990); José M. Marques, Vincent Y. Yzerbyt, and Jacques-Philippe Leyens, The "Black Sheep Effect": Extremity of Judgments Towards Ingroup Members as a Function of Group Identification, 18 Euro J Soc Psych 1, 12-14 (1988).

476 Kleinfeld, et al, $111 \mathrm{Nw}$ U L Rev at 1699 (cited in note 29).

477 See generally Carbado and Richardson, Book Review, 131 Harv L Rev (cited in note 448). Forman himself discusses the black police in Forman, Locking Up Our Own at 78-115 (cited in note 318).

478 Carbado and Richardson, Book Review, 131 Harv L Rev at 1981 (cited in note 448).

479 Id at 1993. See, for example, Joshua Correll, et al, Across the Thin Blue Line: Police Officers and Racial Bias in the Decision to Shoot, 92 J Personality \& Soc Psych 1006, 1011 \& n 3 (2007); Kimberly Barsamian Kahn and Paul G. Davies, Differentially Dangerous? Phenotypic Racial Stereotypicality Increases Implicit Bias Among Ingroup and Outgroup Members, 14 Group Processes \& Intergroup Rel 569, 575-77 (2011).

480 Carbado and Richardson, Book Review, 131 Harv L Rev at 1981 (cited in note 448). 
have to marginalize the concerns of and disassociate themselves from the community of 'black." 481

These forces produce surprising (and disturbing) real-world results: "[E]vidence shows that police departments with more black officers engage in more racial profiling than those with fewer black officers" and "black officers who stop a black man are more likely to arrest him than they are to arrest a stopped white suspect." ${ }^{82}$ Professor Paul Butler cites evidence that "a black cop is more likely to shoot a black person than a white cop is." 483 And at the agency level, there is little evidence that agencies with more black officers use force-in general or against black civilians-less often. ${ }^{484}$ In short, the "unquestioned assumption of racial solidarity between black citizens and black officers" stands on shaky empirical footing and suggests that a deeper, more insidious form of racism is afoot. ${ }^{85}$ The facts suggest that "the pursuit of diversity in the context of policing will not, without more, fundamentally change how African Americans experience the police." ${ }^{486}$

481 Id at 1991.

482 Id at 1994 (citing studies).

483 Paul Butler, Chokehold: Policing Black Men 33 (New Press 2017). A partial explanation may be that "black officers are deployed in areas where they have fewer interactions with white suspects," Butler notes. Id at 34. But he also reviews research that "raises serious concerns about police officers of color." Id. See George Fachner and Steven Carter, Collaborative Reform Initiative: An Assessment of Deadly Force in the Philadelphia Police Department *3 (CNA Corporation 2015), archived at https://perma.cc/RA2G-M7VU (finding that "threat perception failure" involving black suspects is higher among black than white officers).

484 Though not unanimous, the weight of earlier studies finds no significant correlation between black representation in law enforcement and the use of force, deadly or otherwise. Most of these studies, however, relied on deeply flawed measures of force-related incidents. Two more recent papers, which employ significantly better measures, reach similar results with respect to killings of black civilians. See, for example, Joscha Legewie and Jeffrey Fagan, Group Threat, Police Officer Diversity and the Deadly Use of Police Force *33-36 (Columbia Law School Public Law \& Legal Theory Working Paper Group, Paper No 14-512, Dec 2016), archived at https://perma.cc/XRJ2-SY5Y (finding that "minority representation in the police might not reduce the number of officer-involved killings" of black civilians, though it does mitigate the effects of group threat); Sean Nicholson-Crotty, Jill Nicholson-Crotty, and Sergio Fernandez, Will More Black Cops Matter? Officer Race and Police-Involved Homicides of Black Citizens, 77 Pub Admin Rev 206, 211-12 (2017) (finding no significant relationship, or even a positive association, between the proportion of black officers and police-involved killings of black civilians).

485 Forman, Locking Up Our Own at 107 (cited in note 318).

486 Carbado and Richardson, Book Review, 131 Harv L Rev at 1982 (cited in note 448). Indeed, many urban police forces are already quite diverse. See id at 1989-90. 
2. Mixed neighborhoods.

All that said, recall that only a shrinking minority of African Americans actually live in "black neighborhoods" today. What about the millions who live in locales that are predominantly white? Democratization shifts authority over the fate of black defendants in these neighborhoods from judges and bureaucrats to the heterogeneous, though largely white, laity. I need not belabor the proposition that many Americans, especially whites, harbor antiblack bias, even if only implicitly. ${ }^{487}$ Specific to the criminal justice context, many studies have shown "that Americans, and whites in particular, strongly associate crime with racial minorities, and racial minorities with crime." 488 Importantly, individuals (especially whites) who more strongly associate crime with racial minorities, ${ }^{489}$ as well as those (including blacks) who harbor racist attitudes more generally, ${ }^{490}$ are more likely to support punitive criminal justice policies. In fact, white test subjects in one study who were told that "most of the people who are executed are

487 On the gradual transition from "traditional" racism to contemporary, more "laissez-faire" racism, see Lawrence Bobo, James R. Kluegel, and Ryan A. Smith, LaissezFaire Racism: The Crystallization of a Kindler, Gentler, Antiblack Ideology, in Steven A. Tuch and Jack K. Martin, eds, Racial Attitudes in the 1990s: Continuity and Change 15, 23-27 (Praeger 1997). On persistent, overtly racist attitudes about characteristics like work ethic and intelligence, see Lawrence D. Bobo, et al, The Real Record on Racial Attitudes, in Peter V. Marsden, ed, Social Trends in American Life: Findings from the General Social Survey Since 197238 (Princeton 2012). On implicit bias, see Ghandnoosh, Race and Punishment at *14-17 (cited in note 6) (collecting studies).

488 Ghandnoosh, Race and Punishment at *13 (cited in note 6). See id at *13-17 (collecting studies). See also Phillip Atiba Goff, et al, The Essence of Innocence: Consequences of Dehumanizing Black Children, 106 J Personality \& Soc Psych 526, 532 (2014) (finding that black boys are seen as older and less innocent than white boys).

489 See, for example, Ted Chiricos, Kelly Welch, and Marc Gertz, Racial Typification of Crime and Support for Punitive Measures, 42 Crimin 358, 359 (2004); James D. Unnever and Francis T. Cullen, White Perceptions of Whether African Americans and Hispanics Are Prone to Violence and Support for the Death Penalty, 49 J Rsrch Crime \& Delinq 519 (2012); Kelly Welch, et al, The Typification of Hispanics as Criminals and Support for Punitive Crime Control Policies, 40 Soc Sci Rsrch 822 (2011).

490 See generally, for example, Steven E. Barkan and Steven F. Cohn, Racial Prejudice and Support for the Death Penalty by Whites, $31 \mathrm{~J}$ Rsrch Crime \& Delinq 202 (1994); Bobo and Johnson, 1 Du Bois Rev at 164, 170 (cited in note 289); Elizabeth K. Brown and Kelly M. Socia, Twenty-First Century Punitiveness: Social Sources of Punitive American Views Reconsidered, 33 J Quant Crimin 935 (2017); Devon Johnson, Racial Prejudice, Perceived Injustice, and the Black-White Gap in Punitive Attitudes, 36 J Crim Just 198 (2008); Joe Soss, Laura Langbein, and Alan R. Metelko, Why Do White Americans Support the Death Penalty?, 65 J Pol 397 (2003); James D. Unnever and Francis T. Cullen, The Social Sources of Americans' Punitiveness: A Test of Three Competing Models, 48 Crimin 99 (2010). 
African-Americans" were more likely to favor capital punishment than those not given this information. ${ }^{491}$ In short, blacks who live in majority-white neighborhoods may not be seen by whites as in-group members, and thus may not receive the neighborly, in-group treatment the democratizers imagine when they advocate for local lay control.

Substantial evidence shows that these biases, too, seep into the jury box. The process of jury selection is supposed to root this out but few believe it does. ${ }^{492}$ In fact, it may exacerbate the problem, as blacks and Latinos are excluded from juries at disproportionate rates. ${ }^{493}$ For this reason, when recommending an increased role for local juries, Stuntz presents a package of jury reforms he says are crucial to reducing jury bias. ${ }^{494}$ I support these proposals. Yet, at least until they occur, I question the wisdom of entrusting more authority to lay juries in predominantly white communities. As noted earlier, group deliberation can exacerbate rather than mitigate individual biases, including racial bias, especially in close cases. ${ }^{495}$ There is evidence that capital juries discriminate against black defendants, especially those

491 See Mark Peffley and Jon Hurwitz, Justice in America: The Separate Realities of Blacks and Whites 156-57 (Cambridge 2010).

492 Among other things, potential jurors are not always honest during voir dire. See, for example, Linda L. Marshall and Althea Smith, The Effects of Demand Characteristics, Evaluation Anxiety, and Expectancy on Juror Honesty During Voir Dire, 120 J Psych 205, 213 (1986); Richard Seltzer, Mark A. Venuti, and Grace M. Lopes, Juror Honesty During the Voir Dire, 19 J Crim Just 451 (1991).

493 See, for example, Kim Forde-Mazrui, Jural Districting: Selecting Impartial Juries Through Community Representation, 52 Vand L Rev 353, 373-76 (1999); Ronald F. Wright, Kami Chavis, and Gregory S. Parks, The Jury Sunshine Project: Jury Selection Data as a Political Issue, 2018 U Ill L Rev 1407, 1425-26. Blacks, Latinos, and noncitizens are also underrepresented in jury pools. See Mary R. Rose, Raul S. Casarez, and Carmen M. Gutierrez, Jury Pool Underrepresentation in the Modern Era: Evidence from Federal Courts, 15 J Empirical Legal Stud 378, 383, 389 (2018). See also James B. Jacobs, The Eternal Criminal Record 252 (Harvard 2015) ("Most states and the federal government permanently ban convicted felons from jury service."). Convicted felons include 13 percent of all adult males and approximately one-third of all black adult males. Christopher Uggen, Jeff Manza, and Melissa Thompson, Citizenship, Democracy, and the Civic Reintegration of Criminal Offenders, 605 Annals Am Acad Pol \& Soc Sci 281, 304 (2006).

494 See Stuntz, 121 Harv L Rev at 2035 (cited in note 148) (advocating fewer peremptory challenges and more localized jury selection).

495 See sources cited in note 474. But see Iontcheva, $89 \mathrm{Va} \mathrm{L} \mathrm{Rev} \mathrm{at} 364 \mathrm{n} 276$ (cited in note 92) (collecting studies finding that group deliberation mitigates individual bias). 
whose victims are white. ${ }^{496}$ Research from the noncapital context similarly finds racial disparity in jury conviction rates. ${ }^{497}$

The precise effects of neighborhood diversity on jury decisionmaking are indeterminate. On the one hand, there is evidence that even a single African American in the jury pool eliminates the racial gap in conviction rates. 498 While not the only explanation for this striking result, the authors observe that " $[\mathrm{m}]$ ost obviously and directly, having at least one black member in the jury pool makes it feasible to have a black member on the seated jury." "499 "Black representation on the seated jury might affect trial outcomes," in turn, "not only through the jury deliberation and decision process"-if black jurors bring different perspectives, for example, or prompt white jurors to confront their biases 500 —"but also by affecting how the case is presented and argued by the prosecution and

496 See, for example, David C. Baldus, et al, Racial Discrimination and the Death Penalty in the Post-Furman Era: An Empirical and Legal Overview, with Recent Findings from Philadelphia, 83 Cornell L Rev 1638, 1688-90 \& tbl 6 (1998); David C. Baldus and George Woodworth, Race Discrimination in the Administration of the Death Penalty: An Overview of the Empirical Evidence with Special Emphasis on the Post-1990 Research, 39 Crim L Bull 194, 210 (2003) (augmenting the 1998 Philadelphia study); Katherine Beckett and Heather Evans, Race, Death, and Justice: Capital Sentencing in Washington State, 1981-2014, 6 Colum J Race \& L 77, 103-04 (2016); Thomas J. Keil and Gennaro F. Vito, Race and the Death Penalty in Kentucky Murder Trials: An Analysis of Post-Gregg Outcomes, 7 Just Q 189, 203 (1990). Dark-skinned black defendants fare particularly poorly. See, for example, Jennifer L. Eberhardt, et al, Looking Deathworthy: Perceived Stereotypicality of Black Defendants Predicts Capital-Sentencing Outcomes, 17 Psych Sci 383 (2006). But see Baldus and Woodworth, 39 Crim L Bull at 214 (cited in note 496) (asserting that "white-victim disparities are principally the result of prosecutorial charging decisions rather than jury or judicial sentencing decisions"). For evidence from mock jury studies, see Lynch and Haney, Mapping the Racial Bias at 85, 91-95 (cited in note 365); Lynch and Haney, Capital Jury Deliberation at 489, 492-94 (cited in note 365).

497 See, for example, Shamena Anwar, Patrick Bayer, and Randi Hjalmarsson, The Impact of Jury Race in Criminal Trials, 127 Q J Econ 1017, 1048 (2012); Francis X. Flanagan, Race, Gender, and Juries: Evidence from North Carolina, $61 \mathrm{~J}$ L \& Econ 189, 192 (2018). See also Sheri Lynn Johnson, Black Innocence and the White Jury, 83 Mich L Rev 1611, 1616-51 (1985); Nancy J. King, Postconviction Review of Jury Discrimination: Measuring the Effects of Juror Race on Jury Decisions, 92 Mich L Rev 63, 75-100 (1993). Mock jury studies likewise find small but statistically significant effects of race on guilt and sentencing. For reviews, see Tara L. Mitchell, et al, Racial Bias in Mock Juror Decision-Making: A Meta-Analytic Review of Defendant Treatment, 29 L \& Hum Behav 621, 629 (2005); Samuel R. Sommers, Race and the Decision Making of Juries, 12 Legal \& Crim Psych 171, 172-74 (2007).

498 See Anwar, Bayer, and Hjalmarsson, 127 Q J Econ at 1019 (cited in note 497).

499 Id at 1020.

500 On the effects of black representation on jury deliberation, see Samuel R. Sommers, On Racial Diversity and Group Decision Making: Identifying Multiple Effects of Racial Composition on Jury Deliberations, 90 J Personality \& Soc Psych 597, 606-09 (2006). 
defense attorneys." ${ }^{01}$ Likewise, other studies have found that juries with higher proportions of white jurors are more punitive. 502

Yet research into the dynamics of group deliberation suggests that, among heterogeneous jurors, white males of high socioeconomic status tend to become foremen and dominate discussion. ${ }^{503}$ And paradoxically, while a larger black presence in the neighborhood should increase black representation on juries-which may improve outcomes for black defendants-it may simultaneously heighten punitive attitudes among white residents, potentially increasing punishment for all offenders, which, in turn, disparately impacts blacks. This latter, well-documented effect is known as "racial threat." ${ }^{04}$ In fact, blacks, too, are more likely to overestimate

501 Anwar, Bayer, and Hjalmarsson, 127 Q J Econ at 1020 (cited in note 497). See also Sommers, 90 J Personality \& Soc Psych at 603-04 (cited in note 500) (finding that, even before deliberation, white members of diverse mock juries were more lenient toward black defendants than white members of all-white juries).

502 See, for example, David C. Baldus, et al, The Use of Peremptory Challenges in Capital Murder Trials: A Legal and Empirical Analysis, 3 U Pa J Const L 3, 86 fig 7 (2001); William J. Bowers, Benjamin D. Steiner, and Marla Sandys, Death Sentencing in Black and White: An Empirical Analysis of the Role of Jurors'Race and Jury Racial Composition, 3 U Pa J Const L 171, 259 (2001).

503 See, for example, Hans and Vidmar, Judging the Jury at 101, 108 (cited in note 221). See also Devine, Jury Decision Making at 155-56 (cited in note 221) (collecting additional studies).

504 See, for example, Greenberg and West, 39 Crimin at 640 (cited in note 402); Maureen A. Craig and Jennifer A. Richeson, More Diverse Yet Less Tolerant? How the Increasingly Diverse Racial Landscape Affects White Americans' Racial Attitudes, 40 Personality \& Soc Psych Bull 750, 758-59 (2014); David Jacobs and Jason T. Carmichael, The Politics of Punishment Across Time and Space: A Pooled Time-Series Analysis of Imprisonment Rates, 80 Soc Forces 61, 66, 81-82 (2001); David Jacobs and Richard Kleban, Political Institutions, Minorities, and Punishment: A Pooled Cross-National Analysis of Imprisonment Rates, 82 Soc Forces 725, 746-48 (2003); Benjamin Feigenberg and Conrad Miller, Racial Divisions and Criminal Justice: Evidence from Southern State Courts *5-6 (National Bureau of Economic Research Working Paper No 24726, June 2018), archived at https://perma.cc/4LU4-6PSW. Relatedly, whites in more racially diverse neighborhoods overestimate their personal risk of victimization. See generally, for example, Justin T. Pickett, et al, Reconsidering the Relationship Between Perceived Neighborhood Racial Composition and Whites' Perceptions of Victimization Risk: Do Racial Stereotypes Matter?, 50 Crimin 145 (2012); Lincoln Quillian and Devah Pager, Estimating Risk: Stereotype Amplification and the Perceived Risk of Criminal Victimization, 73 Soc Psych Q 79 (2010); Rebecca Wickes, et al, "Seeing” Minorities and Perceptions of Disorder: Explicating the Mediating and Moderating Mechanisms of Social Cohesion, 51 Crimin 519 (2013). Overall, the implications of demographic diversity are something of a paradox: on the one hand, whites are threatened by racial demographic change, which can increase intergroup bias; on the other hand, positive contact with nonwhite neighbors may temper these effects to some degree. See Maureen A. Craig, Julian M. Rucker, and Jennifer A. Richeson, The Pitfalls and Promise of Increasing Racial Diversity: Threat, Contact, and Race Relations in the 21st Century, 27 Current Directions Psychological Sci 188, 191 (2018). 
their neighborhood's crime rates when more racial minorities live nearby. ${ }^{505}$

\section{Judges vs. juries.}

There is cause for concern that ordinary individuals-both black and white-will treat black defendants poorly. But if the alternative is more judicial authority, we must also ask how judges are likely to fare in comparison. Judges, of course, are only human, subject to the same prejudices that afflict us all.506 Racial disparities in sentencing are well established, even with judges rather than juries at the helm. ${ }^{507}$ It would be tempting to infer from this observation that judicial decisions are no more egalitarian than lay ones would be. Such an inference, however, would miss an important wrinkle: judges do not entirely determine criminal sentences. It's not even clear that they're the most important players. 508 Sentences, rather, are the product of a chain of decisions by police officers, prosecutors, defense lawyers, probation officers, and, only then, judges. Racial disparity can creep in at any or all of these stages.

Indeed, recent empirical work questions the extent to which racial disparities in sentencing are attributable to judges at all, at least in jurisdictions with sentencing guidelines. ${ }^{509}$ These studies variously conclude that prosecutorial decisions to seek mandatory minimum sentences explain over half, and possibly all, of

505 See Lincoln Quillian and Devah Pager, Black Neighbors, Higher Crime? The Role of Racial Stereotypes in Evaluations of Neighborhood Crime, 107 Am J Soc 717, 738 (2001); Robert J. Sampson and Stephen W. Raudenbush, Seeing Disorder: Neighborhood Stigma and the Social Construction of "Broken Windows", 67 Soc Psych Q 319, 334-37 (2004).

506 See, for example, Andrea L. Miller, Expertise Fails to Attenuate Gendered Biases in Judicial Decision-Making, 10 Soc Psychological \& Personality Sci 227, 230-33 (2019); Jeffrey J. Rachlinski, et al, Does Unconscious Racial Bias Affect Trial Judges?, 84 Notre Dame L Rev 1195, 1211-26 (2009).

507 See, for example, David B. Mustard, Racial, Ethnic, and Gender Disparities in Sentencing: Evidence from the U.S. Federal Courts, 44 J L \& Econ 285, 296 (2001); Cassia C. Spohn, Thirty Years of Sentencing Reform: The Quest for a Racially Neutral Sentencing Process, 3 Crim Just 427, 474 (2000).

508 See, for example, William J. Stuntz, Plea Bargaining and Criminal Law's Disappearing Shadow, 117 Harv L Rev 2548, 2559-62 (2004) (describing prosecutorial control over sentences in both guidelines and discretionary sentencing jurisdictions).

509 In addition, a number of earlier studies find little evidence of judicial discrimination at sentencing. See, for example, Alfred Blumstein, Racial Disproportionality of U.S. Prison Populations Revisited, 64 U Colo L Rev 743, 749, 754 (1993); Stephen Klein, Joan Petersilia, and Susan Turner, Race and Imprisonment Decisions in California, 247 Science 812, 815-16 (1990). See also Michael Tonry, Malign Neglect: Race, Crime, and Punishment in America 65-70 (Oxford 1995). 
the federal racial sentencing disparity; 510 that United States $v$ Booker, ${ }^{511}$ which expanded judicial sentencing discretion, did not increase racial disparities; 512 and that, to the extent that Booker did affect black defendants adversely, the effects were due to changes in prosecutorial charging behavior, while judges used their discretion to mitigate disparity. ${ }^{513}$

I do not mean to suggest that these findings, all of which are based on federal sentencing data, are conclusive. Other recent studies are more reluctant to write off the judicial contribution to sentencing disparities. ${ }^{514}$ Nevertheless, the weight of evidence suggests that police and prosecutors, rather than judges, are responsible for at least some, and possibly much (or even all), of the observable racial disparity in ultimate outcomes. Judges, in other words, likely deserve less blame for disparities than they commonly receive. And there is plenty of room, so to speak, for jury sentencing to be worse.

Perhaps this shouldn't surprise. Judges are, after all, trained and expected to be impartial. And while they don't escape all psychological irrationality, ${ }^{515}$ there is some evidence that they fare

510 See M. Marit Rehavi and Sonja B. Starr, Racial Disparity in Federal Criminal Sentences, 122 J Pol Econ 1320, 1323-24, 1343 (2014). See also Byungbae Kim, Cassia Spohn, and E.C. Hedberg, Federal Sentencing as a Complex Collaborative Process: Judges, Prosecutors, Judge-Prosecutor Dyads, and Disparity in Sentencing, 53 Crimin 597, 61518 (2015) (finding that disparity attributable to prosecutors is larger than disparity from judges).

511543 US 220 (2005).

512 See Sonja B. Starr and M. Marit Rehavi, Mandatory Sentencing and Racial Disparity: Assessing the Role of Prosecutors and the Effects of Booker, 123 Yale L J 2, 9 (2013).

513 See id; Joshua B. Fischman and Max M. Schanzenbach, Racial Disparities Under the Federal Sentencing Guidelines: The Role of Judicial Discretion and Mandatory Minimums, 9 J Empirical Legal Stud 729, 730, 761 (2012). Taking a broader, twenty-year perspective, Professors Fischman and Schanzenbach also find that "racial disparities were generally lower during periods when judges had wider discretion, suggesting that judges exercise discretion in a manner that mitigates disparity." Id at 730. See also Emily Owens, Erin M. Kerrison, and Bernardo Santos Da Silveira, Examining Racial Disparities in Criminal Case Outcomes Among Indigent Defendants in San Francisco *2-3 (Penn Law, 2017), archived at https://perma.cc/UY59-XPU9 (finding that racial disparities in criminal case outcomes are attributable to nonjudicial factors).

514 See, for example, Crystal S. Yang, Free at Last? Judicial Discretion and Racial Disparities in Federal Sentencing, 44 J Legal Stud 75, 77, 105 (2015) (finding that Booker increased "judicially induced disparities"); Alma Cohen and Crystal S. Yang, Judicial Politics and Sentencing Decisions, 11 Am Econ J: Econ Pol 160, 184-85 (2019) (concluding that observed disparities "are not solely driven by prosecutorial discretion" and that "judges play an important role in explaining disparities in sentencing").

515 See, for example, Chris Guthrie, Jeffrey J. Rachlinski, and Andrew J. Wistrich, Inside the Judicial Mind, 86 Cornell L Rev 777, 817-18 (2001); Jeffrey J. Rachlinski, Andrew J. Wistrich, and Chris Guthrie, Can Judges Make Reliable Numeric Judgments? 
better than laypeople in combatting certain biases. ${ }^{516}$ On race, specifically, one recent study finds that, although judges (like everyone else) harbor implicit racial bias, these biases only sometimes influence actual judgment, possibly because judges attempt to compensate to avoid making biased judgments. ${ }^{517}$ Moreover, there is evidence that judges' racial bias decreases with experience, ${ }^{518}$ an important maturation process that is impossible for one-shot jurors.

\section{E. Compliance}

The final premise of democratization is that, by allowing the people to participate in criminal justice, and by aligning the law with community values, democratization will bolster the system's legitimacy and moral credibility, respectively, leading to improved compliance and cooperation and engagement with authorities. Despite their thematic similarities, the literatures on "procedural justice" and "empirical desert"-both of which claim the ability to improve compliance-have developed separately, based on distinct bodies of empirical research. I address them separately here. I also discuss some of the potentially pernicious effects of embracing these theories of community-empowering justice.

\section{Procedural justice.}

In a literature widely known within criminal justice circlesand endorsed by the President's Task Force on 21st Century Policing-Professors Tom Tyler, Tracey Meares, and others maintain that individuals are more likely to obey the law when they

Distorted Damages and Skewed Sentences, 90 Ind L J 695, 696-97, 717, 731 (2015); Wistrich, Guthrie, and Rachlinski, $153 \mathrm{U}$ Pa L Rev at 1259 (cited in note 362).

516 See, for example, Guthrie, Rachlinski, and Wistrich, 86 Cornell L Rev at 817 (cited in note 515) (finding that judges are less susceptible than jurors to two widespread cognitive biases); Jeffrey J. Rachlinski, Chris Guthrie, and Andrew J. Wistrich, Probable Cause, Probability, and Hindsight, 8 J Empirical Legal Stud 72, 93 (2011) (finding that judges' probable cause determinations are not clouded by hindsight); Susanne M. Schmittat and Birte Englich, If You Judge, Investigate! Responsibility Reduces Confirmatory Information Processing in Legal Experts, 22 Psych Pub Pol \& L 386, 395 (2016) (finding that criminallaw experts, including judges, exhibited less confirmatory information processing than laypeople); Wistrich, Guthrie, and Rachlinski, $153 \mathrm{U}$ Pa L Rev at 1321 (cited in note 362) (finding that judges can ignore evidence obtained in violation of a defendant's right to counsel).

517 See Rachlinski, et al, 84 Notre Dame L Rev at 1221-23 (cited in note 506).

518 See, for example, David Arnold, Will Dobbie, and Crystal S. Yang, Racial Bias in Bail Decisions, 133 Q J Econ 1885, 1890, 1929 (2018); Cohen and Yang, 11 Am Econ J: Econ Pol at 178 (cited in note 514). 
view legal authorities as legitimate. Perceptions of legitimacy, in turn, depend on whether the authorities govern in a procedurally just fashion-which itself hinges significantly on whether the citizenry is given voice in matters of the state. ${ }^{519}$ In the democratization agenda, procedural justice operates on two planes: on the wholesale level, "the public wants to be listened to when policies are being created"; on the retail level, people want "an opportunity to state their case when dealing with individual police officers." ${ }_{20}$ As discussed above, the former lies closer to democratization's core and the latter, its periphery.

On the wholesale level, one empirical criticism observes that "most of the evidence for the positive effects of voice has been generated in studies of legal arrangements or other situations in which the decision maker has no vested material interest in a particular outcome." ${ }_{221}$ "[A]s soon as the setting is shifted to one in which the decision maker . . . might receive differentiated payoffs depending upon the decision rendered," in contrast, "any salubrious effects of voice vanish and are replaced by 'frustration' effects." ${ }_{22}$ This latter scenario might describe legislators working with citizen advisory boards to refine the criminal code, who are posturing for reelection, or prosecutors or police at community justice meetings, who are managing their workloads. Or, at least, participating citizens may view these officials this way. Some of Tyler's own research tends to confirm this result. Tyler finds, for example, that the perceived ability to make arguments to or influence

519 See Tyler, Rasinski, and McGraw, 15 J Applied Soc Psych at 715-21 (cited in note 162$)$.

520 Meares, $111 \mathrm{Nw} \mathrm{U} \mathrm{L} \mathrm{Rev} \mathrm{at} 1531$ (cited in note 32).

521 Hibbing and Theiss-Morse, Stealth Democracy at 197 (cited in note 234) (citation omitted). See also Robert J. MacCoun, Voice, Control, and Belonging: The Double-Edged Sword of Procedural Fairness, 1 Ann Rev L \& Soc Sci 171, 192 (2005) ("[M]any of the most robust procedural fairness effects have involved civil disputes between pairs of ordinary citizens, where outcomes are equivocal with respect to their implications for the system.").

522 Hibbing and Theiss-Morse, Stealth Democracy at 197 (cited in note 234), citing Ronald L. Cohen, Procedural Justice and Participation, 38 Hum Rel 643 (1985) and Robert Folger, Distributive and Procedural Justice: Combined Impact of Voice and Improvement on Experienced Inequity, $35 \mathrm{~J}$ Personality \& Soc Psych 108 (1977). For other evidence of deliberative frustration, see Amy Gangl, Procedural Justice Theory and Evaluations of the Lawmaking Process, 25 Pol Behav 119, 136 (2003); Michael E. Morrell, Citizens' Evaluations of Participatory Democratic Procedures: Normative Theory Meets Empirical Science, 52 Pol Rsrch Q 293, 300, 315 (1999); Randall S. Peterson, Can You Have Too Much of a Good Thing? The Limits of Voice for Improving Satisfaction with Leaders, 25 Personality \& Soc Psych Bull 313, 322 (1999). 
the decisions of a political body does not lead subjects to be more favorable toward that body, and sometimes just the opposite. ${ }^{523}$

A separate critique counsels caution in our optimism about procedural justice at the retail level, in everyday interactions between officers and civilians. To be clear, there is considerable evidence that procedurally just treatment induces cooperation in certain other settings, such as the workplace. ${ }^{524}$ The research on policing, however, is largely associational; a "credible case for causality has not been made." ${ }^{25}$ What is more, the evidence of compliance effects we do have focuses "only on compliance with an officer's on-scene directive, not on longer-term compliance with the law and future police orders." ${ }_{526}$

Criminologists Robert Worden and Sarah McLean report several pertinent findings in their recent book. First, the actual, observed procedural justice with which officers act explains a little more than one-tenth of the variation in individuals' subjective perceptions of procedural justice. ${ }^{527}$ Procedural injustice shapes perceptions more potently. ${ }^{528}$ Relatedly, "citizens' assessments of whether the outcome they received was the outcome they deserved . . . are not a reflection of officers' procedural justice." ${ }_{529}$ Far more important are general attitudes about the police that citizens carry into encounters. ${ }^{530}$

523 See Tom R. Tyler, Psychological Models of the Justice Motive: Antecedents of Distributive and Procedural Justice, 67 J Personality \& Soc Psych 850, 858 (1994).

524 See National Academies of Sciences, Engineering, and Medicine, Proactive Policing: Effects on Crime and Communities 232-36 (National Academies 2018).

525 Daniel S. Nagin and Cody W. Telep, Procedural Justice and Legal Compliance, 13 Ann Rev L \& Soc Sci 5, 7 (2017).

526 Id at 14. Consider M. Alper Sozer, Crime and Community Policing 144 (LFB Scholarly 2009) ("This book did not find any evidence to justify the crime reduction effect of community policing.").

527 Worden and McLean, Mirage of Police Reform at 136 (cited in note 252). See also Nagin and Telep, 13 Ann Rev L \& Soc Sci at 11 (cited in note 525).

528 See Worden and McLean, Mirage of Police Reform at 179 (cited in note 252). See also Edward R. Maguire, Belén V. Lowrey, and Devon Johnson, Evaluating the Relative Impact of Positive and Negative Encounters with Police: A Randomized Experiment, $13 \mathrm{~J}$ Experimental Crimin 367, 385-86 (2017); Wesley G. Skogan, Asymmetry in the Impact of Encounters with Police, 16 Policing \& Socy 99, 118-19 (2006).

529 Worden and McLean, Mirage of Police Reform at 143 (cited in note 252).

$530 \mathrm{Id}$ at 185 ("What citizens take away from their encounters with the police in the form of their attitudes toward the police is shaped by what they brought to their encounters much more than by what police do."). See Jacinta M. Gau, Procedural Justice and Police Legitimacy: A Test of Measurement and Structure, 39 Am J Crim Just 187, 202-04 (2014). See also Belén V. Lowrey, Edward R. Maguire, and Richard R. Bennett, Testing the Effects of Procedural Justice and Overaccommodation in Traffic Stops: A Randomized Experiment, 43 Crim Just \& Behav 1430, 1445 (2016); Nagin and Telep, 13 Ann Rev L \& Soc Sci at 15-17 (cited in note 525) (reviewing additional studies). 
Second, "[t]he use of police authority" such as searches or physical force "has a bearing on subjective experience"-including perceived procedural justice- "independent of the procedural justice with which authority is exercised." ${ }^{531}$ Put differently, " $[w]$ hether officers used their authority-by using physical force or conducting searches-proved to be much more important than how officers used their authority-their procedural (in)justicein shaping citizens' assessments of procedural justice." 332

Third, introducing, at monthly departmental meetings, reports on citizens' subjective experiences with the police "did not generally result in detectable improvements over time." ${ }_{33}$ "Superimposed on existing structures," Worden and McLean conclude, "the procedural justice model is likely to be [ ] loosely coupled with police practice" on the ground.534 This echoes a large body of evidence on community policing, a related and partially overlapping policing model. After all, contemporary policing is community policing. ${ }^{535}$ Yet the community-oriented aspects of the communitypolicing approach, scholars have consistently found, "rarely intrude[] much on the operational autonomy of the police." ${ }_{336}$

Interestingly, Tyler himself largely agrees with all of this: "The case for the effectiveness of [the procedural justice] model in the arena of policing has not been made," he writes. ${ }^{537}$ According to Tyler, "it is not social science researchers who have been pushing the rapid . . . application of these ideas to policing"; rather, "it

531 Worden and McLean, Mirage of Police Reform at 148 (cited in note 252).

532 Id at 12. See also Charles R. Epp, Steven Maynard-Moody, and Donald HaiderMarkel, Pulled Over: How Police Stops Define Race and Citizenship 133 (Chicago 2014) ("It is simply not true that if officers remain professionally respectful they can carry out as many investigatory stops as they wish without causing harm.").

533 Worden and McLean, Mirage of Police Reform at 165 (cited in note 252).

534 Id at 183. But see Jonathan Jackson and Ben Bradford, Book Review, Mirage of Police Reform, for Special Issue of Police Practice and Research, 19 Police Prac \& Rsrch: Intl J 204, 206 (2018) (agreeing that cultural change within organizations is hard but contending that Worden and McLean did not allow enough time).

535 See, for example, Sklansky, Democracy and the Police at 2 (cited in note 13) (calling community policing "a new orthodoxy" ascendant over the past four decades); Stuntz, Collapse of American Criminal Justice at 293 (cited in note 15) (similar).

536 Sklansky, Democracy and the Police at 97 (cited in note 13). See also, for example, Worden and McLean, Mirage of Police Reform at 24-25 (cited in note 252). See also generally Tony Cheng, Input Without Influence: The Silence and Scripts of Police and Community Relations, 67 Soc Probs 171 (2020); William Terrill and Stephen D. Mastrofski, Working the Street: Does Community Policing Matter?, in Skogan, ed, Community Policing 109 (cited in note 231) (finding no systematic relationship between community policing assignments, officer training, and attitudes and the extent to which officers used coercion).

537 Tom Tyler, Procedural Justice and Policing: A Rush to Judgment?, 13 Ann Rev L \& Soc Sci 29, 32 (2017). 
is legal and governmental authorities seeking insights for dealing with a pressing national problem: public distrust in the police." 538 Without the luxury of time to wait for further research, and given that "considerable evidence available in other arenas" supports the "potential value" of the procedural justice model "in addressing issues of police legitimacy," Tyler concludes, "the widespread reliance upon this work by authorities seem[s] reasonable." 539

I am more concerned than Tyler about the wisdom of grounding policy in this unsettled body of research. If the procedural justice model does not improve policing the way its proponents hope, it's a distraction from the pressing imperative to find something that will. (With respect, my own reading of the literature on procedural justice in policing suggests considerably more faith in the empirics among social scientists - or at least legal scholars-than Tyler professes.) In fact, given the way procedural justice is heralded as a "community-based approach," 540 it may be worse than a distraction. It may actually expand police discretion by stamping it with the "community's" imprimatur. ${ }^{541}$

Consider two examples. First, the Supreme Court has sanctioned police activity carried out in the name of "the community" that the Fourth Amendment might otherwise condemn. It has adopted a broad "community caretaking" exception to the probable cause requirement, which licenses great intrusions-including entry into the home-when police have an "objectively reasonable basis" to believe their assistance is needed. ${ }^{542}$ It has also upheld suspicionless searches of parolees as a means of "reducing recidivism and thereby promoting reintegration and positive citizenship" ${ }_{433}$ and suspicionless stops of "responsible citizens" to look for witnesses to a crime, promoting "public safety." 544 As Sklansky observes, "The Court's rhetoric in both of these [latter] cases resonated strongly with a view of the police as an arm of 'the community." ${ }_{545}$

538 Id at 31

539 Id at 32

540 See National Academies of Sciences, Engineering, and Medicine, Proactive Policing at 211 (cited in note 524).

541 For an extended argument with similar themes - that efforts to implement direct, participatory democracy give rise to institutions that end up expanding the scope and authority of the state, see generally James A. Morone, The Democratic Wish: Popular Participation and the Limits of American Government (Yale rev ed 1998).

542 See Brigham City, Utah v Stuart, 547 US 398, 400 (2006).

543 Samson v California, 547 US 843, 853 (2006).

544 Illinois $v$ Lidster, 540 US 419, 425 (2004).

545 Sklansky, Democracy and the Police at 43 (cited in note 13). 
Second, the Court has pointed to the presence of civilian review as justifying relaxing the Fourth Amendment's exclusionary rule. Doctrine requires the police to "knock and announce" before entering a home to execute a warrant. In Hudson $v$ Michigan, ${ }^{546}$ the Court considered the remedy for a violation of this rule. In holding that exclusion of evidence was unnecessary, the Court identified legal and institutional developments that had occurred since it had applied the exclusionary rule to the states in 1961. Among these was "the increasing use of various forms of citizen review [that] can enhance police accountability." 547 The Court did not actually cite any evidence for this point, and the empirical research to date is mixed, at best. Indeed, just three years before the Court decided Hudson, Judge Debra Livingston, who served nearly a decade on New York City's Civilian Complaint Review Board, penned an article tellingly titled The Unfulfilled Promise of Citizen Review. ${ }^{548}$ In fact, some think that common types of civilian review may undermine accountability by diffusing responsibility and muddling the chain of command. ${ }^{549}$

\section{Empirical desert.}

Professors Josh Bowers and Paul Robinson echo these critiques. They contrast procedural justice with a model of "empirical desert" in which laws that are "morally credible," because they are substantively just, induce greater compliance. ${ }^{550}$ For this reason, Bowers and Robinson argue, as between procedural legitimacy and moral credibility, "moral credibility ought to be the principal objective in uncommon circumstances in which a system may effectively pursue only one." 551

The problem is that the evidence for these "compliance effects" is shaky, as Robinson has occasionally admitted. ${ }^{552}$ In nearly all of the prior work Robinson cites, researchers investigated whether a law's moral credibility affects the stated likelihood of

546547 US 586 (2006).

547 Id at 599.

548 Livingston, 1 Ohio St J Crim L 653 (cited in note 82). See also Worden and McLean, Mirage of Police Reform at 27 (cited in note 252) ("[T] here is no evidence that citizen oversight alters patterns of police behavior or performance.”).

549 See George E. Berkley, The Democratic Policeman 146-47 (Beacon 1969).

550 See Bowers and Robinson, 47 Wake Forest L Rev at 216, 259, 282 (cited in note 201).

551 Id at 213.

552 See, for example, Paul H. Robinson, Reply, in Robinson, Garvey, and Ferzan, eds, Criminal Law Conversations 61, 63 (cited in note 200) (agreeing "that our current knowledge regarding [empirical desert's crime-control] effects is limited"). 
compliance with that law, not with the law more generally. ${ }^{553}$ Robinson's own studies present lay participants with vignettes involving criminal sentences that, by conjecture, are grossly disproportionate to anticipated views of just desert. ${ }^{554}$ Learning of these sentences, Robinson finds, reduces participants' expressed willingness to comply and cooperate with the law. ${ }^{555}$ Yet Robinson detects only slight anticipated compliance effects from massively unjust sentences, such as a fifty-year sentence for a nineteenyear-old who reasonably believed the minor with whom he had consensual sex was an adult.556 Professors Christopher Slobogin and Lauren Brinkley-Rubenstein, in their own original research, "find little evidence that divergence from societal views about punishment ... significantly increases willingness to break the law or diminishes respect for it, especially once the passage of time makes the divergence less salient." ${ }_{557}$

There is an additional concern with the moral credibility argument: existing research does not distinguish between the credibility of outcomes in individual cases and that of the system as a whole. In other words, the data do not show whether people regard a system as morally credible when outcomes in individual cases are perceived as just but the systemic effects are not. After all, sentences are not the only systemic input that matters-budgets, police and prosecutorial discretion, and a host of other factors unrelated to sentencing go far toward determining how much punishment the system doles out and to whom.

\section{F. The Collision Course}

If there's anything to the arguments I've just made, the "large tent" of democratization may, in due time, devolve into civil war. As a group, the democratizers pledge allegiance both to principles

553 See Slobogin and Brinkley-Rubenstein, 65 Stan L Rev at 97 (cited in note 198). One exception is Janice Nadler, Flouting the Law, 83 Tex L Rev 1399 (2005). Professor Nadler finds some evidence that exposure to unfair legal outcomes increases subjects' willingness to contemplate noncompliance with other laws. Id at 1415-16. Altogether, however, her evidence is mixed, and she concludes that "[i] $\mathrm{t}$ is undoubtedly false that perceived injustice in the legal system leads to greater willingness to break the law for all people, in all circumstances, at all times." Id at 1440. See also Slobogin and Brinkley-Rubenstein, 65 Stan L Rev at 102 (cited in note 198) (conjecturing that "any survey measure of perceptions about the likelihood one will violate the law has minimal external validity").

554 See Robinson, Goodwin, and Reisig, 85 NYU L Rev at 1965 (cited in note 125).

555 See id at 2002-07.

556 See id.

557 See Slobogin and Brinkley-Rubenstein, 65 Stan L Rev at 100 \& n 102 (cited in note 198). 
and policies, on the one hand, and to particular purposes they say those principles and policies will promote, on the other. The latter are the democratizers' ends; the former, means conjectured to achieve those ends. What I have gone to great pains to demonstrate is that the democratizers' means may very well fail to achieve their ends-and may even undermine them. The democratizers' dual commitments - to both means and ends-are likely on a collision course.

What happens if I am right? This broad coalition, I expect, will fracture. One camp will contain those principally committed to the ends of dismantling our system of racialized mass incarceration. To them, democratization is a tool that can be discarded when it proves itself useless. Their belief in democratization is shallow and contingent; they wish to effectuate community values only when those values promote their own reform prescriptions. Meares, for example, characterizes herself as "largely sympathetic" to the democratization agenda, at least as it concerns policing, but argues that "citizen engagement . . . should be structured and rationalized toward a particular end." ${ }_{558}$ But who chooses the "particular end"? Experts, I assume. On this view, the people matter only insofar as they provide strategic cover forand legitimation of - what is ultimately an expert-driven agenda.

The other camp will encompass those who will follow the people virtually wherever they lead. Their principal commitment is to a methodology of governance. Such a conviction is defensible on various grounds. But it does not grant one membership in the resistance. Decarceration, if it occurs, would be a happy side effect of democratization for these scholars. Robinson, for example, does not flinch when his studies find that, outside the context of "crime control" doctrines, laypeople prefer sentences higher than those the law regularly doles out. ${ }^{559}$

The democratization coalition, then, is a preciously fragile one. It is sometimes said that the vague and capacious concept of "democracy" makes strange bedfellows. ${ }^{560}$ The same is true, I mean to suggest, of democratization. There is, one might argue, nothing wrong with that as long as both sides keep the bed warm. What troubles me, though, is that any victories the democratizers

\footnotetext{
558 Meares, $111 \mathrm{Nw}$ U L Rev at 1526 (cited in note 32).

559 See notes 326-27 and accompanying text.

560 See Morone, The Democratic Wish at 9, 11 (cited in note 541).
} 
score for the decarceral agenda will be fleeting. ${ }^{561}$ History suggests that, at some point, crime rates will spike or a sensational murder will capture the public imagination. Attitudes will grow more punitive; racial tensions may flare. ${ }^{562}$ The democratizers committed to principles of lay rule and empirical desert will urge us to follow the rising tide, to let the people lead. Those committed to decarceration will be deserted.

\section{CONCLUSION: ALTERNATIVE VISIONS OF "DEMOCRATIC" CRIMINAL JUSTICE}

America does indeed seem to be in the midst of a criminal justice "moment." 563 The critical question is what to do with the opportunities this moment creates. The democratizers wave us away from experts and bureaucracy and toward a model of thoroughgoing lay participation in the criminal justice process and its institutions. For all the reasons given, their agenda leaves me cold. But where to turn instead?

The literature does not lack for alternative models, all of which might justifiably claim the mantle of "democracy," variously understood. These models are not mutually exclusive, either conceptually or pragmatically. Scholars on the radical left, building upon vibrant social movements, advocate bold reforms ranging from community control to abolition to the "Black People's Grand Jury," ideas designed to empower and liberate marginalized members of the polity to act within existing legal structures, to transform those structures, or to create their own. ${ }^{564}$ Others advance a public-health conception of criminal justice, in which legal institutions aim to rehabilitate, or treat, the individuals

561 Consider Derrick Bell, Silent Covenants: Brown v. Board of Education and the Unfulfilled Hopes for Racial Reform 151 (Oxford 2004).

562 See note 321 and accompanying text.

563 See, for example, First Step Act of 2018, Pub L No 115-391, 132 Stat 5194.

564 See, for example, Danielle Sered, Until We Reckon: Violence, Mass Incarceration, and a Road to Repair (New Press 2019); Amna A. Akbar, Toward a Radical Imagination of Law, 93 NYU L Rev 405 (2018); Monica C. Bell, The Community in Criminal Justice: Subordination, Consumption, Resistance, and Transformation, Du Bois Rev *12-14 (forthcoming), archived at https://perma.cc/N2FC-KMXV. See also generally, for example, Brie McLemore, Procedural Justice, Legal Estrangement, and the Black People's Grand Jury, 105 Va L Rev 371 (2019); Allegra M. McLeod, Prison Abolition and Grounded Justice, 62 UCLA L Rev 1156 (2015); Roberts, 111 Nw U L Rev 1597 (cited in note 32); Simonson, 111 Nw U L Rev 1609 (cited in note 32). 
brought before them and return them to full democratic participation. ${ }^{565} \mathrm{~A}$ third camp, to which I am-perhaps unsurprisinglysympathetic, emphasizes an evidence-based approach to criminal justice problem-solving focused on achieving outcomes consistent with democratic values.

The basic idea that criminal justice policy ought to be grounded in evidence is not new. In 1967, the President's Commission on Law Enforcement and Administration of Justice concluded that the "greatest need" of "law enforcement and the administration of [] justice" was "the need to know." 566 The Commission recommended an ambitious national research strategy, including an independent body like the National Science Foundation, to support a rational approach to crime control.567 Subsequent scientific advances, however, long went ignored. ${ }^{568}$ Things may finally be starting to change. "Lawmakers and policymakers are beginning to rely more on evidence-informed methods not only to achieve public safety and reduce incarceration," scholars have documented, "but also to improve the quality of evidence used in courtrooms, to improve policing through technology, and to gather better data on criminal justice operations." 569

Indeed, a number of the democratizers' own proposals betray some allegiance to these principles. Consider, for example, the democratizers' suggestions to reduce the use of imprisonment,

565 See, for example, Amy J. Cohen, Trauma and the Welfare State: A Genealogy of Prostitution Courts in New York City, 95 Tex L Rev 915, 955 (2017) (describing modern "problem-solving courts" that reflect "ideas of self-empowerment, self-sufficiency, and individual participation and responsibility").

566 President's Commission on Law Enforcement and Administration of Justice, The Challenge of Crime in a Free Society 273 (GPO 1967).

567 See id at 274-77.

568 "The creation of governmental institutions that sponsor and fund research, the development of university departments in criminal justice and criminology, and the accumulation of large sophisticated scientific literatures," Michael Tonry lamented in 2013, "have not resulted in the development of evidence-based policies as a norm in American criminal justice systems." Michael Tonry, Evidence, Ideology, and Politics in the Making of American Criminal Justice Policy, 42 Crime \& Just: Rev Rsrch 1, 11-12 (2013).

569 Brandon L. Garrett, Evidence-Informed Criminal Justice, 86 Geo Wash L Rev 1490, 1493 (2018). See generally, for example, Francis T. Cullen, Andrew J. Myer, and Edward J. Latessa, Eight Lessons from Moneyball: The High Cost of Ignoring EvidenceBased Corrections, 4 Victims \& Offenders 197 (2009); Brandon L. Garrett and John Monahan, Judging Risk, 108 Cal L Rev (forthcoming 2020), archived at https:// perma.cc/7VCG-EKMZ; Cecelia Klingele, The Promises and Perils of Evidence-Based Corrections, 91 Notre Dame L Rev 537 (2016); Jennifer E. Laurin, Gideon by the Numbers: The Emergence of Evidence-Based Practice in Indigent Defense, 12 Ohio St J Crim L 325 (2015); Lawrence W. Sherman, The Rise of Evidence-Based Policing: Targeting, Testing, and Tracking, 42 Crime \& Just: Rev Rsrch 377 (2013). 
moderate prison conditions, and force the entities that prosecute and sentence to internalize the costs of prosecution and incarceration. The democratizers do not propose to consult the public on these general topics. Nor do they claim widespread public support for, say, cost internalization. There is no obvious role here for lay participation and there's no reason to think laypeople are necessary-or even helpful-in achieving these outcomes. These proposals are the stuff of experts and bureaucrats. And they are best justified using social science evidence. ${ }^{570}$ The same might be said of procedural justice.

Committing to foreground "evidence" is only a first step. What remains are difficult questions about what sorts of evidence we need and who-laypeople or experts (and what kind of experts)—will supply that evidence. Also key are questions of institutional design. For ease of exposition, I have so far accepted the democratizers' notion that the world divides into expert and lay perspectives and institutions. In reality, most "democratic" institutions combine expertise and popular input in different ways and measures.

Professor Rachel Barkow, for example, advocates an administrative-law model that "looks more like the way we make policy in other regulatory areas where expertise plays a more significant role." ${ }_{571}$ The premise-with which I tend to agree-

570 On decarceration, see David Roodman, The Impacts of Incarceration on Crime *7 (Open Philanthropy Project, 2017), archived at https://perma.cc/AW9T-MG75 (concluding, in a thorough review of the literature, that "the best estimate of the impact of additional incarceration on crime in the United States today is zero" and that "there is as much reason overall to believe that incarceration increases crime as decreases it") (emphasis omitted). On prison conditions, see M. Keith Chen and Jesse M. Shapiro, Do Harsher Prison Conditions Reduce Recidivism? A Discontinuity-Based Approach, 9 Am L \& Econ Rev 1, 21 (2007); Francesco Drago, Roberto Galbiati, and Pietro Vertova, Prison Conditions and Recidivism, 13 Am L \& Econ Rev 103, 122 (2011); Gerald G. Gaes and Scott D. Camp, Unintended Consequences: Experimental Evidence for the Criminogenic Effect of Prison Security Level Placement on Post-Release Recidivism, 5 J Experimental Crimin 139, 153 (2009) (finding that harsher prison conditions likely increase recidivism). On cost internalization, see Itai Ater, Yehonatan Givati, and Oren Rigbi, Organizational Structure, Police Activity and Crime, $115 \mathrm{~J}$ Pub Econ 62, 66-67 (2014) (finding that cost internalization in Israel reduced incarceration); Aurélie Ouss, Incentive Structures and Criminal Justice *17-18 (unpublished manuscript, Dec 2017), archived at https://perma.cc/QP5S-28NU (similar in California).

571 Barkow, Prisoners of Politics at 3 (cited in note 41). For additional recent takes on an administrative-law approach to criminal justice governance, see Pfaff, Locked In at 222-23 (cited in note 303) (proposing a prison-closing commission, free from oversight and review, to escape the pork-barrel and logrolling politics that prevent politicians from closing prisons); Barry Friedman and Maria Ponomarenko, Democratic Policing, 90 NYU L Rev 1827 (2015); Christopher Slobogin, Policing as Administration, 165 U Pa L Rev 91 (2016). 
is that "empirically valuable information on criminal law can lead to better decisions," meaning "decisions that improve public safety and human lives at a lower cost." 572 "The average American citizen," Barkow continues, "is not on equal footing with an expert who studies the data in achieving these goals"; "when it comes to public safety and maximizing limited resources," in other words, "there is such a thing as expertise that can improve decisionmaking." ${ }_{573}$ At the same time, administrative law recognizes in various ways that ordinary people may know things the experts do not, and that lay contributions and feedback are crucial to wellinformed regulation. ${ }^{574}$

An evidence-based approach, to be clear, is not necessarily antagonistic toward lay participation or community-based solutions. Its posture is contingent and skeptical, in a scientific sense. If reliable evidence shows these solutions to work, great-run with them. ${ }^{575}$ The skepticism that pervades Part II pertains largely to whether reliable evidence does exist to support the democratizers' proposals. Nor does an evidence-based approach obviate the need to engage in difficult value judgments. What does it mean, after all, for a criminal justice reform to "work"? Does a procedural justice model "work" if it enhances the legitimacy of the police, and increases citizen compliance, without improving substantive or distributive justice? Some say not, 576 but reasonable

572 Barkow, Prisoners of Politics at 167 (cited in note 41). Barkow gives a simple example: "[I]f a jurisdiction wants to pursue imprisonment but a drug treatment program could achieve the same public safety results at a lower cost and without unnecessary confinement, that treatment program should be used." Id at 166.

573 Id at 168.

574 See Cass R. Sunstein, The Cost-Benefit Revolution 79-99 (MIT 2018).

575 Consider Trevor George Gardner, Right at Home: Modeling Sub-Federal Resistance as Criminal Justice Reform, 46 Fla St U L Rev 527, 534 (2019) (advocating "instrumental" rather than "ideological" sub-federal resistance to state and federal criminal justice policy).

576 Various scholars argue that, even if the procedural justice model does work, there are serious normative concerns with legitimating, through procedural justice techniques, a system that is substantively unjust. The basic concern "is that authorities can use the appearance of fair procedure ... as an inexpensive way to coopt citizens and distract them from outcomes that by normative criteria might be considered substantively unfair or biased." MacCoun, 1 Ann Rev L \& Soc Sci at 189 (cited in note 521). "Any procedural justice reforms," Paul Butler urges, "need to be accompanied by substantive reforms if they are to have an impact beyond public relations." Butler, Chokehold at 198 (cited in note 483). Indeed, "[d]eploying legitimacy theory and procedural justice as a diagnosis and solution to the current policing crisis," Professor Monica Bell cautions, "might even imply . . . that the problem of policing is better understood as a result of African American criminality than as a badge and incident of race- and class-based subjugation." Bell, 126 Yale L J at 2061 (cited in note 11). Or as Professor Dorothy Roberts puts it, more acerbically: "It is 
people could disagree, depending upon their ranking of competing societal values. What evidence contributes is a realistic understanding of which values are served and disserved, and to what extent.

In all events, the choice between more and less "democracy" is a false one. The critical questions are what values we want our criminal justice system to serve and what kind of democracy is likeliest to realize them. The latter question, in turn, requires us to contemplate how best to blend accountability to the public with various kinds of criminal justice expertise. These are difficult questions that I put off for another day. But they are ones we should be asking.

nonsensical to believe an anti-democratic system can be fixed by ensuring greater obedience from the very people it is designed to subordinate." Roberts, $111 \mathrm{Nw}$ U L Rev at 1604 (cited in note 32 ). 